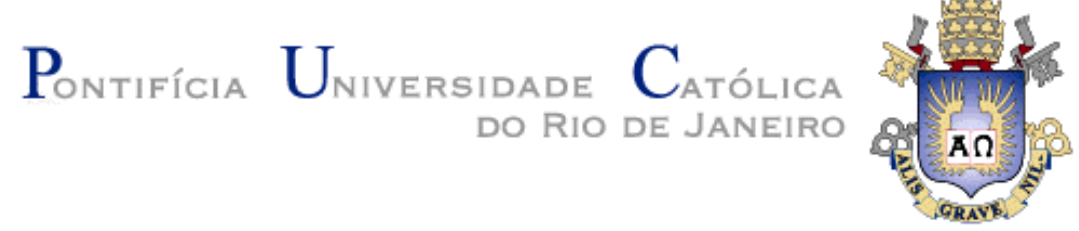

Flávio Tito Peixoto Filho

\title{
Modelo para Determinação do Comprimento Ótimo Testemunhado em Arenitos Inconsolidados
}

\section{Tese de Doutorado}

Tese apresentada ao Programa de Pós-graduação em Engenharia Civil da PUC-Rio como requisito parcial para obtenção do grau de Doutor em Engenharia Civil.

Orientador: Prof. Eurípedes Amaral Vargas Jr. Co-Orientador: Prof. Erick Slis Raggio Santos 


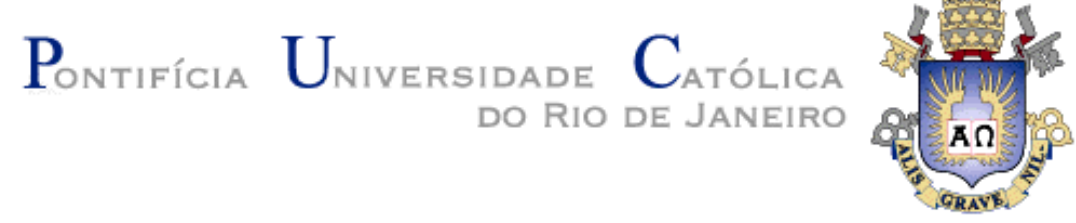

Flávio Tito Peixoto Filho

\section{Modelo para Determinação do Comprimento Ótimo Testemunhado em Arenitos Inconsolidados}

Tese apresentada como requisito parcial para obtenção do grau de Doutor pelo Programa de Pós-Graduação em Engenharia Civil da PUC-Rio. Aprovada pela Comissão Examinadora abaixo assinada.

Eurípedes do Amaral Vargas Júnior Orientador Departamento de Engenharia Civil e Ambiental - PUC-Rio

Erick Slis RaggioSantos

Co-Orientador PETROBRAS/CENPES

Sérgio Augusto Barreto da Fontoura Departamento de Engenharia Civil e Ambiental - PUC-Rio

Raquel Quadros Velloso Departamento de Engenharia Civil e Ambiental - PUC-Rio

Andrea Ferreira Borges Universidade Federal do Rio de Janeiro

Francisco Henriques Ferreira PETROBRAS/CENPES

Prof. Márcio da Silveira Carvalho Coordenador(a) Setorial do Centro Técnico Científico - PUC-Rio 
Todos os direitos reservados. É proibida a reprodução total ou parcial do trabalho sem autorização da universidade, do autor e do orientador.

\section{Flávio Tito Peixoto Filho}

Graduado em Engenharia de Controle e Automação pela Universidade Federal de Santa Catarina. Mestre em Metrologia pela mesma instituição. Em setembro de 2004 ingressou na Petrobras iniciando a especialização em Engenharia de Petróleo. Desde 2005 trabalha na área de construção de poços marítimos, se dedicando à atividade de testemunhagem, entre outras. Ministra cursos sobre o tema em cursos internos e externos à Petrobras.

Ficha Catalográfica

Peixoto Filho, Flávio Tito

Modelo para determinação do comprimento ótimo testemunhado em arenitos inconsolidados / Flávio Tito Peixoto Filho ; orientadores: Eurípedes Amaral Vargas Jr., Erick Slis Raggio Santos. - 2017.

152 f. : il. color. ; $30 \mathrm{~cm}$

Tese (doutorado)-Pontifícia Universidade Católica do Rio de Janeiro, Departamento de Engenharia Civil, 2017.

Inclui bibliografia

1. Engenharia civil - Teses. 2. Acunhamento. 3. Testemunho. 4. Recuperação. 5. Testemunhagem. 6. Mecânica das rochas. I. Vargas Júnior, Eurípedes do Amaral. II. Santos, Erick Slis Raggio. III. Pontifícia Universidade Católica do Rio de Janeiro. Departamento de Engenharia Civil. IV. Título. 
Dedico esse trabalho ao meu recém-chegado filho Martín. Uma alegria muito grande ao meu coração e de minha esposa. Nós te amamos, filho!

Dedico também à minha mãe, Dona Nazareth, que infelizmente nos deixou em 2013 e vem fazendo muita falta. 


\section{Agradecimentos}

A Deus, acima de tudo.

À minha esposa Renata, companheira e parceira em grandes e difíceis desafios. Teria sido impossível enfrentá-los sem seu apoio.

A meu pai e toda minha família.

À Petrobras, por todo o suporte, e pelo crédito depositado em mim.

Aos colegas de trabalho, por "segurarem as pontas" enquanto me deslocava ao Rio para assistir as aulas do doutorado.

Aos meus orientadores, Erick e Vargas, pela disposição e paciência em me orientar.

Ao amigo e colega de trabalho Irineu Soares, mentor na atividade de testemunhagem

À PUC e seu corpo de funcionários e professores.

À equipe do CENPES pelo apoio nos experimentos.

Ao laboratório de Sedimentologia e Estratigrafia da Bacia de Campos, pelo empréstimo da amostra de arenito.

Ao Bruno, ao Maxwell e à oficina dos Serviços Especiais pelo apoio no experimento do plano inclinado.

Ao Jose Thomaz, ao Fernando Peral e ao Serviço de Fluidos pela disponibilização das amostras de fluido de perfuração e ajuda nas descrições. 


\section{Resumo}

Peixoto Filho, Flavio Tito. Vargas Jr., Eurípedes Amaral (Orientador); Santos, Erick Slis Raggio (Co-orientador). Modelo para Determinação do Comprimento Ótimo Testemunhado em Arenitos Inconsolidados. Rio de Janeiro, 2017. 152p. Tese de Doutorado - Departamento de Engenharia Civil, Pontifícia Universidade Católica do Rio de Janeiro.

Nas operações de testemunhagem o acunhamento é uma preocupação permanente. Denomina-se acunhamento quando a amostra de rocha não prossegue adentrando no barrilete de testemunhagem devido à fricção entre a rocha $\mathrm{e}$ superfície interna do barrilete. Em formações resistentes é indesejável por causar perda de tempo e prejuízo econômico, principalmente caso ocorra logo no início da corrida. Em formações inconsolidadas o prejuízo vai além, pois pode causar a perda da rocha a ser testemunhada, uma vez que a baixa resistência compressiva causa o colapso da rocha. Sendo em muitos casos não detectado na superfície, a operação não é interrompida e o trecho seguinte da rocha-reservatório passa a ser destruído. Uma previsão do comprimento a ser testemunhado até que esse evento ocorra pode ser uma maneira importante de minimizar a destruição de rocha, maximizando sua recuperação, sem o ônus de ser conservador demais. Este trabalho descreve os passos e resultados de se estabelecer um modelo para prever o acunhamento em formações inconsolidadas. Esses passos incluem: experimentos para determinar o coeficiente de fricção entre a areia e os tubos de alumínio, modelagem analítica e análise por elementos finitos para a avaliação dos resultados dos experimentos e para estabelecer o modelo de previsão.

\section{Palaras-chave}

Acunhamento; Testemunho; Recuperação; Testemunhagem; Mecânica das Rochas; Formações inconsolidadas. 


\section{Abstract}

Peixoto Filho, Flavio Tito. Vargas Jr., Eurípedes Amaral (Orientador); Santos, Erick Slis Raggio (Co-orientador). On Modeling the optimum Rock Coring Length of Unconsolidated Sandstones prior to Core Jamming. Rio de Janeiro, 2017. 152p. Tese de Doutorado - Departamento de Engenharia Civil, Pontifícia Universidade Católica do Rio de Janeiro.

In coring operations core jamming is a permanent concern. It takes place when the core sample becomes stuck within the inner core barrel, preventing further acquisition. In hard formations it is undesirable because it stops bit penetration, and results in loss of time and money, especially if it occurs at the beginning of the core run. In unconsolidated formations the damage goes further, as the jam may become solidary to the coring bit and wash the formation away instead of acquiring it. This phenomenon is unnoticeable at surface and thus gives the operators no indicative of a premature pull out of hole need. The reservoir rock characterization will be permanently incomplete due to the unrecovered washed away material. Hence, a good prediction of a safe maximum coring length could be an important way to avoid washing the sample, maximizing recovery, without risking to be too conservative. This work describes the steps and results of establishing a model to predict jamming in unconsolidated formations. These steps includes: experiments to determine friction factor between sand and the aluminum tubes, analytical modeling, and FEM analysis to evaluate the experiment results and to establish the prediction model.

\section{Keywords}

Coring; Core Jamming; Core Recovery; Rock Mechanics; Unconsolidated Formations. 


\section{Sumário}

1 Introdução 19

1.1. Motivação e objetivos 19

1.2. Estrutura 22

2 Análise do Problema 23

2.1. Revisão bibliográfica 23

2.2. Descrição de um sistema de testemunhagem padrão 25

2.3. O acunhamento em linhas gerais 32

2.4. Parâmetros determinantes na ocorrência do acunhamento 37

2.5. Como as companhias de serviço de testemunhagem tratam o acunhamento 40

2.6. O contato entre superfícies e o atrito 43

2.6.1. O modelo de Coulomb 43

2.6.2. O plano inclinado $\quad 45$

2.7. Modelagem analítica inicial 46

2.7.1. Modelo Analítico do Acunhamento 47

2.7.2. Modelo do cisalhamento 51

2.7.3. Acrescentando o peso próprio do testemunho ao modelo analítico inicial 53

2.8. Modelo analítico proposto 57

2.9. Influência do fluido de perfuração no atrito 61

2.10. Relações entre as grandezas na compactação de uma coluna de areia no interior do tubo de alumínio 63

2.10.1. Esforços na parede do tubo 63

2.10.2. Comportamento mecânico de areias 65

2.11. Modelagem no método dos elementos finitos (MEF) 67

2.11.1. Ferramenta utilizada - o programa Abaqus 67

2.11.2. Modelando a plasticidade no Abaqus utilizando o modelo de

Drucker-Prager com fechamento de envoltória (cap) 69 
2.11.3. Interação entre superfícies 71

2.11.3.1. Propriedade das interações entre as superfícies 72

2.11.4. Modelos para o atrito 74

2.11.5. Aplicação do carregamento 75

2.11.6. Malha e elementos $\quad 77$

2.12. Modelagem hidráulica - SIMCARR 78

3 Metodologia $\quad 79$

3.1. Método de abordagem 79

3.2. Experimentos para determinação do coeficiente de atrito 79

3.2.1. Experimento de translação do tubo envolvendo coluna de areia compactada 80

3.2.1.1. Etapas do experimento 82

3.2.1.2. Roteiro de preparação e execução do experimento 84

3.2.1.3. Especificações do sistema de aquisição da deformação 87

3.2.1.4. Propriedades da areia utilizada 88

3.2.1.5. Dimensões e posicionamento 89

3.2.2. Experimento do plano inclinado 92

3.3. Modelagem do caso real através do MEF 95

4 Execução e Resultados dos Experimentos $\quad 97$

4.1. Experimento de translação do tubo através de coluna de areia $\begin{array}{ll}\text { compactada } & 97\end{array}$

4.1.1. Ensaio-teste destrutivo em um segmento de tubo vazio 97

4.1.2. Ensaio-teste no tubo de alumínio instrumentado com strain $\begin{array}{ll}\text { gauges } & 100\end{array}$

4.1.3. Execução do experimento de translação do tubo através da $\begin{array}{ll}\text { areia compactada } & 101\end{array}$

4.1.3.1. Fase de compactação da areia 102

4.1.3.2. Fase de translação do tubo 103

4.1.4. Resultados 104

4.1.5. Determinando os parâmetros da areia 107

4.2. Resultados do experimento do plano inclinado 115 
5 Modelagem em Elementos Finitos

5.1. Modelagem da compactação da areia no interior do tubo 117

5.1.1. Geometria de análise 117

5.1.2. Materiais 118

5.1.3. Condições de contorno 120

5.1.4. Carregamento 120

5.1.5. Malha de elementos finitos 121

5.1.6. Resultados obtidos 123

5.2. Modelagem do acunhamento 127

5.2.1. Conceito e geometria do modelo 127

5.2.2. Propriedades dos Materiais 129

5.2.3. Dinâmica e condições de contorno 131

5.2.4. Malha e tipo de elementos utilizados 133

5.2.5. Interação entre as superfícies 134

5.2.6. Resultados dos modelos em EF para o acunhamento 134

5.2.6.1. Resultados: simulações com diferentes tensões no topo 136

5.2.6.2. Resultados: comparação entre os diferentes diâmetros e fluídos de perfuração 138

5.2.7. Comparação entre os resultados da simulação e o modelo analítico

139

6 Conclusões e perspectivas futuras 141

6.1. Conclusões 141

6.2. Dificuldades enfrentadas 143

6.3. Perspectivas Futuras 145

7 Referências Bibliográficas 146

8 Anexos 150

8.1. Anexo 1 - Dados obtidos a partir da compactação da areia $\quad 150$

8.2. Anexo 2 - Recuperação nas testemunhagens no arenito turbidítico de referência 


\section{Lista de figuras}

Figura 1.1: Região com testemunho confinado (1) e região de ruptura (2)

Figura 2.1: Desenho esquemático dos principais componentes em um sistema de testemunhagem padrão.

Figura 2.2: Coroa de insertos de PDC, apropriada para formações de baixa resistência, portas na face de ataque direcionam a maior parte do fluxo o distanciando da amostra de rocha (face discharge)

Figura 2.3: Desvio do fluxo para o anular entre os tubos externo e interno após o assentamento da esfera

Figura 2.4: Aranha, componente responsável pela retenção da amostra de testemunho

Figura 2.5: Acunhamento do tipo 1, típico em testemunhos com fraturas naturais ou induzidas

Figura 2.6: Exemplos de fraturas induzidas capazes de provocar o acunhamento [4]

Figura 2.7: Acunhamento do testemunho que na impossibilidade de prosseguir adentrando o barrilete fraturou próximo à sua base 35

Figura 2.8: Acunhamento do tipo 2, em formações inconsolidadas; desagregação parcial da rocha preenche o espaço entre a amostra de rocha e o tubo

Figura 2.9: Representação do modelo de Coulomb

Figura 2.10: Bloco no plano inclinado, exemplo acadêmico clássico para explicar os princípios da força de atrito [8]

Figura 2.12: Esforços atuando sobre o cilindro de rocha durante a testemunhagem [3]

Figura 2.11: Esforços atuando sobre o cilindro de rocha durante a testemunhagem [3]

Figura 2.13: Modelos para a amostra acunhada e confinada no interior do tubo e para o trecho não confinado no qual a rocha sofre o colapso [2] 
Figura 2.14: Modelo do cisalhamento

Figura 2.15: Círculo de Mohr para o trecho de rocha não confinado

Figura 2.16: Dinamismo nos esforços entre a amostra de rocha e o tubo

Figura 2.17: Discretização do problema estado inicial $(\mathrm{t}=0)$

Figura 2.18: Discretização do problema estado seguinte $(\mathrm{t}=1)$

Figura 2.19: Modelo de Drucker-Prager com cap [10]

Figura 2.20: interação entre superfícies na condição Hard-contact [10]

Figura 2.21: Modelo de decaimento exponencial para o coeficiente de atrito em função da taxa de deslizamento (slip rate) [10]

Figura 2.22: Penalty friction, modelo de penalidade do Abaqus [10]

Figura 2.23: Cota do cilindro $(\mathrm{cm}) \times$ deformação circunferencial $(\mu \mathrm{m} / \mathrm{m})$; efeitos inerciais podem afetar os resultados

Figura 2.24: Suavização aplicada ao carregamento, Smooth step amplitude [10]

Figura 2.25: Malha customizada pelo usuário a partir de seleção manual de pontos ao longo das extremidades

Figura 3.1: Seções dos tubos de alumínio utilizados no interior dos barriletes de testemunhagem

Figura 3.2: Tubos de alumínio após a instalação das rosetas extensométricas

Figura 3.3: Tampas e êmbolos projetados com dimensões compatíveis ao tubo de alumínio selecionado para o experimento.

Figura 3.4: Fase de compactação

Figura 3.5: Fase de deslocamento ou translação

Figura 3.6: Módulo de aquisição com ponte de Wheatstone

Figura 3.7: Eliminação das impurezas na areia utilizada

Figura 3.8: Peneira mesh 12, utilizada na limpeza da amostra de 88 areia 
Figura 3.9: Dimensões do aparato e posicionamento dos strain gauges

Figura 3.10: Aparato construído para realização de tilt test avaliação do coeficiente de atrito entre a amostra de arenito e o tubo

Figura 3.11: Amostra de arenito utilizada no experimento

Figura 4.1: Amostra de tubo de alumínio instrumentada para ensaio de compressão uniaxial

Figura 4.2: Tensão $\times$ Deformação para ensaio de compressão uniaxial em tubo de alumínio com diâmetro de 5,25 in [MPa]

Figura 4.3: Diagrama da relação entre as deformações lateral e axial (Poisson) em função da tensão axial (MPa) no tubo de alumínio

Figura 4.4: Tubo de alumínio instrumentado para fase de compactação da areia

Figura 4.5: tubo de alumínio instrumentado para a fase de deslocamento relativo tubo-areia. Apesar de exibidos na foto, os plugues usados como suporte para o tubo são removidos antes do início da aplicação da carga

Figura 4.6: diagrama força $x$ deslocamento para fase de translação do ensaio de areia compactada com $50 \mathrm{kN}$

Figura 4.7: relação entre a força necessária para deslocar o tubo em função da carga usada para a compactação da areia

Figura 4.8: Relação entre a carga aplicada e o curso da prensa nas trajetórias de carregamento e descarregamento

Figura 4.9: topo do tubo de alumínio, mostrando a areia compactada após o teste com compressão de $80 \mathrm{kN}$ de força axial Figura 4.10: No ensaio com carregamento de $50 \mathrm{kN}$ um segundo ciclo foi realizado após $120 \mathrm{~min}$ de repouso

Figura 4.11: componente de deformação elástica determinada na trajetória de descarregamento

Figura 4.12: trajetória de carregamento no diagrama de Cambridge 
Figura 5.1: Modelo axissimétrico contendo o tubo, a areia e o êmbolo superior

Figura 5.2: Materiais incorporados ao modelo

Figura 5.3: Aplicação do carregamento e condições de contorno

Figura 5.4: Êmbolo aplicando carregamento sobre a coluna de areia

Figura 5.5: Malhas aplicadas aos componentes do modelo

Figura 5.6: Distribuição de deformação circunferencial ao longo da parede do tubo $(\mathrm{cm})$ para diferentes coeficientes de atrito, comparando com os dados obtidos experimentalmente. Modelo elástico equivalente

Figura 5.7: Distribuição de deformação longitudinal ao longo da parede do tubo $(\mathrm{cm})$ para diferentes coeficientes de atrito, comparando com os dados obtidos experimentalmente. Modelo elástico equivalente.

Figura 5.8: Distribuição de deformação circunferencial ao longo da parede do tubo $(\mathrm{cm})$ para diferentes coeficientes de atrito, comparando com os dados obtidos experimentalmente. Modelo elasto-plástico.

Figura 5.9: Distribuição de deformação longitudinal ao longo da parede do tubo $(\mathrm{cm})$ para diferentes coeficientes de atrito, comparando com os dados obtidos experimentalmente. Modelo elasto-plástico.

Figura 5.10: Modelo axissimétrico incorporando a amostra de testemunho,o tubo utilizado na testemunhagem e um segundo tubo que têm o papel de simular o engaste da coluna de rocha em sua extremidade inferior

Figura 5.11: Detalhe do bisel na extremidade do tubo minimizando interferência na entrada da amostra no interior do tubo

Figura 5.12: Janela de inserção dos parâmetros do arenito

Figura 5.13: Tela do Simcarr, utilizado para a estimativa do diferencial de pressão sobre a esfera desviadora de fluxo 
Figura 5.15: Mapa de cores mostra as concentrações de tensão, em vermelho o carregamento no topo exercido pelo fluido; em azul claro a zona de maior tensão axial no trecho não confinado

Figura 5.16: Resultados de diversas simulações com diferentes tensões no topo, todas elas para testemunho de 4 polegadas $\mathrm{e}$ utilizando o coeficiente de atrito para fluido de base aquosa $(0,41)$ Figura 5.17: Comparação entre os resultados das simulações com diferentes diâmetros e fluidos de perfuração, tensão no topo de $38470 \mathrm{~Pa}$ 


\section{Lista de tabelas}

Tabela 1: Resultados da deformação medida pelas rosetas extensométricas durante carregamento axial sobre o tubo vazio

Tabela 2: Dados de deformação plástica para estabelecer os parâmetros de endurecimento

Tabela 3: Resultados dos experimentos do plano inclinado em termos de inclinação máxima para atrito estático

Tabela4: Dimensões adotadas na simulação

Tabela 5: Comparação entre os resultados da simulação e o modelo analítico 


\section{Lista de Símbolos}

$\mathrm{P}$ perda de carga no jato $\left[\mathrm{FL}^{-2}\right]$

$\mathrm{MW}$ massa específica do fluido de perfuração $\left[\mathrm{FL}^{-3}\right]$

$Q \quad$ vazão $\left[\mathrm{L}^{3} \mathrm{~T}^{-1}\right]$

Aj área dos jatos $\left[\mathrm{L}^{2}\right]$

$\mathrm{Cd}$ coeficiente dos jatos [-]

$\theta$ inclinação do plano [graus]

$\mathrm{m}$ massa $[\mathrm{M}]$

m.g Força peso [F]

Hest coeficiente de atrito estático [ADIM]

Fat Força de atrito $[\mathrm{F}]$

WOB peso sobre broca (Weight on Bit) [F]

$\mu$ coeficiente de atrito [ADIM]

Fn Força normal $[\mathrm{F}]$

$\sigma_{N}$ Tensão normal [ $\left.\mathrm{FL}^{-2}\right]$

WOB peso sobre broca [F]

Y taxa de deslizamento [ADIM]

D diâmetro interno do tubo de alumínio [L]

$\sigma_{c}$ tensão circunferencial $\left[\mathrm{FL}^{-2}\right]$

$\sigma_{1}$ tensão vertical $\left[\mathrm{FL}^{-2}\right]$

$\sigma_{3}$ tensão horizontal $\left[\mathrm{FL}^{-2}\right]$

d diâmetro interno do cilindro [L]

$t$ espessura de parede do cilindro [L]

$\mathrm{u}$ pressão interna no cilindro [ $\left.\mathrm{FL}^{-2}\right]$

$\sigma_{\text {l }}$ tensão longitudinal (axial) $\left[\mathrm{FL}^{-2}\right]$

$\varepsilon_{c}$ deformação circunferencial [ADIM]

$\varepsilon \mid$ deformação longitudinal (axial) [ADIM]

E módulo de Young $\left[\mathrm{FL}^{-2}\right]$

v coeficiente de Poisson [ADIM]

p componente hidrostática do tensor de tensão $\left[\mathrm{FL}^{-2}\right]$ 
q componente desviadora do tensor de tensão (diagrama de Lambe) $\left[\mathrm{FL}^{-2}\right]$

t componente desviadora do tensor de tensão (diagrama de Cambridge) $\left[\mathrm{FL}^{-2}\right]$

$\beta$ ângulo de inclinação da trajetória (diagrama de Cambridge) [ $\left.\mathrm{FL}^{-2}\right]$

$\Phi$ porosidade [ADIM]

$\varnothing$ ângulo de atrito [ADIM]

$\mathrm{K}$ módulo volumétrico [ADIM]

Eur módulo de Young da fase elástica da areia, obtido no descarregamento ou recarregamento $\left[\mathrm{FL}^{-2}\right]$

$\rho$ peso específico $\left[\mathrm{FL}^{-3}\right]$

I comprimento de contato entre a amostra e o tubo [L]

UCS resistência à compressão simples [ $\left.\mathrm{FL}^{-2}\right]$

$\sigma_{y}$ tensão axial no trecho de testemunho não confinado $\left[\mathrm{FL}^{-2}\right]$

$\sigma_{y i}$ tensão axial inicial no trecho de testemunho não confinado $\left[\mathrm{FL}^{-2}\right]$ 


\section{1 \\ Introdução}

1.1.

Motivação e objetivos

$\mathrm{Na}$ exploração de hidrocarbonetos a obtenção de amostras de testemunho é de extrema importância para uma boa caracterização do reservatório que, por sua vez, subsidia o planejamento de como o campo será desenvolvido. Nem mesmo as mais modernas ferramentas de perfilagem são capazes de fornecer informações equivalentes àquelas obtidas diretamente da amostra de rocha. Entretanto, a execução da testemunhagem envolve um elevado custo, uma vez que atrasa o cronograma de construção do poço. Não sendo nada desprezível o custo diário de uma sonda (principalmente se tratando de poços no subsolo marinho), é importante que o tempo de uma operação de testemunhagem seja otimizado. No entanto, ainda mais importante é a otimização do índice de recuperação das amostras, evitando a necessidade de repetição da testemunhagem em outro poço no mesmo reservatório.

Uma preocupação constante em uma operação de testemunhagem é a ocorrência do acunhamento. Denomina-se acunhamento quando a entrada da amostra de testemunho no interior do barrilete de testemunhagem é interrompida devido a fatores friccionais. Pode-se dizer que o acunhamento, uma vez ocorrido, não tem solução. A única alternativa é a retirada do poço do barrilete de testemunhagem. Cada ocorrência de um acunhamento prematuro implica na necessidade de substituição do barrilete para a amostragem do trecho desejado restante.

Nos dias atuais, uma plataforma de perfuração no mar pode chegar a um custo diário da ordem de um milhão de dólares, se incluídos os custos da logística de suporte. Uma descida extra de barrilete pode atrasar o cronograma em dois a cinco dias, causando uma elevação considerável nos custos.

Tratando-se de formações inconsolidadas e de baixa resistência compressiva, tomando como exemplo os reservatórios de arenitos turbidíticos da Bacia de Campos, a ocorrência do acunhamento está muitas vezes associada a outro problema, a baixa taxa de recuperação do testemunho. A partir do momento em que a força de atrito do testemunho com o tubo de alumínio que o envolve 
atinge um valor equivalente à resistência compressiva da rocha, a amostra de testemunho, não sendo capaz de suportar o peso que vinha sendo aplicado sobre a broca, cisalha na sua extremidade inferior. Quando isso acontece, dificilmente os sintomas são percebidos na superfície, e então se começa a destruir a formação ao invés de amostrá-la, com a coroa de testemunhagem plugada pelo testemunho se comportando como uma broca comum (ver Figura 1.1).

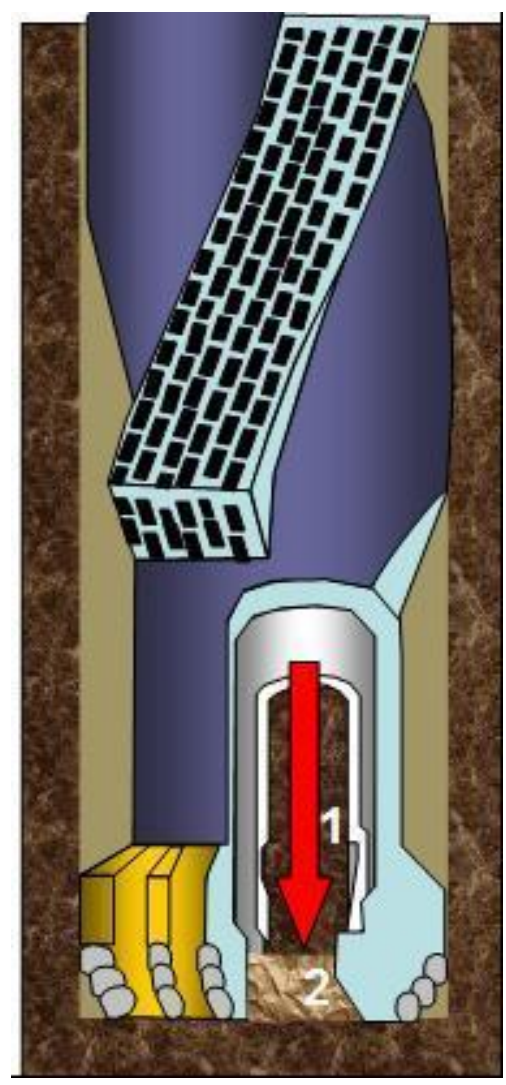

Figura 1.1: Região com testemunho confinado (1) e região de ruptura (2)

Torna-se importante prever qual o comprimento, em média, no qual a rocha é capaz de ser testemunhada antes que o acunhamento ocorra. Tal previsão torna possível minimizar a perda de testemunho sem comprometer o desempenho operacional.

$\mathrm{Na}$ ausência da previsão, uma campanha de testemunhagem pode ser iniciada com uma postura ousada ou conservadora demais, a depender do comprimento de testemunho por corrida adotado inicialmente. Somente no decorrer da campanha (e se esta for extensa o suficiente) os operadores têm a 
chance de conhecer a extensão de rocha possível ser recuperada em cada vez, ao custo de um processo de tentativa e erro.

Uma postura conservadora consiste em iniciar a campanha de testemunhagem recuperando uma extensão excessivamente diminuta de rocha em cada corrida, e somente então aumentar essa extensão gradativamente, corrida após corrida, na medida em que se confirme uma recuperação total na tentativa anterior. A depender da extensão total a ser testemunhada, tal prática torna exorbitante o custo da operação de testemunhagem. Como agravante, a manobra de retirada do testemunho até a superfície deve ser realizada em velocidade controlada, de modo a evitar ou minimizar as fraturas provocadas pela expansão dos hidrocarbonetos presentes nos poros da rocha reservatório, à medida que é trazida a pressões hidrostáticas cada vez menores, o que torna a operação ainda mais demorada.

Em outro extremo, uma postura ousada consiste em iniciar a campanha com uma tentativa de recuperação maior em cada corrida, reduzindo a extensão somente nas tentativas seguintes caso a recuperação não tenha sido total. Neste caso, assume-se o risco de se perder uma considerável parcela da amostra nas primeiras tentativas, após uma eventual e assintomática ocorrência do acunhamento. Tal prejuízo, embora de difícil monetização, impõe restrições severas à geologia e à engenharia de reservatório, que desta forma não irão dispor de uma amostra contínua. Em certas ocasiões, uma nova operação de testemunhagem é realizada em um próximo poço no mesmo campo, apenas para recuperar uma zona não amostrada na primeira testemunhagem. Ainda assim não satisfazendo totalmente, uma vez que as locações são diferentes.

Desta forma, este trabalho tem a intenção de estudar o fenômeno do acunhamento de forma mais aprofundada, e assim oferecer algumas respostas à atividade. Em especial, uma diretriz que permita uma melhor estimativa do comprimento ótimo a ser testemunhado em uma rocha inconsolidada. Para atingir esse objetivo, é oferecido um modelo analítico que representa o fenômeno. Esse modelo é então validado através da comparação com os resultados obtidos em simulações computacionais. 


\section{2.}

\section{Estrutura}

A estrutura do presente trabalho é dividida em oito capítulos.

O capítulo 1 apresentou a introdução do tema.

O capítulo 2 tem o objetivo de ambientar o leitor ao problema e às questões que o envolvem. Contém uma revisão bibliográfica sobre o assunto, descreve o funcionamento e os principais componentes de um sistema de testemunhagem, explana sobre o acunhamento e introduz sobre as ferramentas empregadas no trabalho. O capítulo ainda aborda os modelos analíticos do problema. Primeiramente o modelo proposto por terceiros e em seguida o modelo proposto neste trabalho.

O capítulo 3 descreve a metodologia empregada no trabalho, detalha a idealização dos experimentos e as modelagens computacionais adotadas.

O capítulo 4 é dedicado a relatar a execução dos experimentos e os resultados obtidos, assim como o tratamento aplicado em tais resultados.

O capítulo 5, por sua vez, relata o desenvolvimento dos modelos em Elementos Finitos, do experimento e do caso real. O capítulo ainda analisa e comenta os resultados obtidos.

No capítulo 6 são apresentadas as conclusões do trabalho, e ilustradas possíveis contribuições de tais conclusões na prática da atividade de testemunhagem. Adicionalmente, o capítulo comenta as dificuldades enfrentadas e termina sugerindo possíveis estudos complementares.

Finalmente, os capítulos 7 e 8 consistem nas referências bibliográficas e anexos, respectivamente. 


\section{2 \\ Análise do Problema}

\section{1.}

\section{Revisão bibliográfica}

Apesar de ser uma preocupação constante na testemunhagem, o acunhamento é um assunto pouco abordado na bibliografia. Os poucos artigos que abordam o assunto o fazem por meio de estudo de caso, e parecem ter como intuito defender a eficácia de determinadas tecnologias "anti-acunhamento" oferecidas por companhias de serviço [1], além de serem geralmente voltados ao acunhamento em formações fraturadas [2]. Para entender a razão, é necessário conhecer como funciona a atividade de testemunhagem na indústria do Petróleo. As companhias petrolíferas não costumam dispor de um setor dedicado à atividade de testemunhagem. Quando necessitam tal operação, contratam uma companhia prestadora desse tipo de serviço, e delegam a esta companhia a responsabilidade de toda a operação. Entretanto, não fornecem a ela informações muito específicas a respeito da rocha a ser testemunhada, seja por não entenderem a importância, ou por considerá-las informações estratégicas e sigilosas demais para serem compartilhadas. Tais companhias prestadoras de serviços de testemunhagem, por sua vez, estudam o acunhamento com o intuito de desenvolver produtos que minimizem tal ocorrência de uma forma geral. Além de não terem interesse algum em permitir o acesso dos concorrentes aos resultados de tais estudos, não executam uma análise customizada.

A única fonte com grande relação ao estudo proposto é o trabalho realizado por uma equipe da Petrobras e divulgado em evento interno da companhia [3]. Tal trabalho pode ser considerado como ponto de partida desta tese. Nele os autores fizeram um modelo analítico de previsão do comprimento a ser testemunhado antes do acunhamento. Utilizaram ainda dados de campo de testemunhagens passadas de modo a inferir o produto entre a força normal e a força de atrito ( $\mu . N)$. Apesar de sua simplicidade o modelo orientou os comprimentos máximos esperados em cada testemunhagem.

Um artigo publicado em 1981 [4] relacionou o percentual de recuperação em arenitos consolidados com a resistência compressiva, sem mencionar o acunhamento. Apesar de aparentemente não ter levado em conta o comprimento 
da barriletada, sabe-se que na época esse comprimento era tipicamente de 9 metros, pois as sondas operavam com uma configuração na qual o avanço ocorre adicionando os tubos de perfuração por unidade. Tal estudo possui algumas semelhanças com etapas do estudo realizado neste trabalho. Aparentemente, os resultados apresentados naquele artigo são mais pessimistas em relação ao modelo de acunhamento previsto pela equipe da Petrobras. Tal diferença é perfeitamente compreensível. O primeiro motivo é que existem outras causas para uma baixa taxa de recuperação além do acunhamento, e tais episódios estão incluídos nos dados do autor. Além disso, deve-se considerar a evolução das coroas e demais equipamentos de testemunhagem, assim como dos equipamentos das sondas de perfuração, de 1981 a 2007.

O presente trabalho consiste primeiramente em analisar o fenômeno do acunhamento sob um ponto de vista acadêmico para estabelecer um modelo que permita prever durante o planejamento da testemunhagem, com uma razoável precisão, o comprimento que determinada rocha admite ser testemunhada em cada tentativa. O trabalho para obter tal resultado engloba três etapas: um componente analítico como ponto de partida, experimentos para a obtenção do coeficiente de atrito entre a rocha e o barrilete de testemunhagem e modelagens em elementos finitos de forma a simular o caso real.

Conforme mencionado anteriormente, um estudo pioneiro com este intuito foi realizado dentro da Petrobras e divulgado em evento interno na companhia. O estudo permitiu finalmente substituir uma abordagem operacional por uma previsão científica para ao se definir o comprimento ótimo a ser testemunhado.

No entanto, o modelo em questão pode ser refinado, melhorando a estimativa de determinados parâmetros, ou incorporando aspectos não considerados no estudo inicial. Há margem para melhoria na determinação mais precisa dos coeficientes de atrito entre a rocha e os tubos de alumínio oferecidos pelas companhias de serviço; na incorporação da influência de outras variáveis, como a natureza do fluido de perfuração utilizado e o diâmetro do testemunho; utilizar ferramentas computacionais de modelagem de modo a tratar o problema de uma forma menos simplificada, e desta forma mais próxima da realidade.

Um modelo analítico alternativo do fenômeno é apresentado neste trabalho. Criado a partir dos modelos constitutivos que compõem o problema, e valendo-se da relação "auto-dependente" do atrito e da força normal exercida pela rocha na 
parede do tubo, que gera um comportamento exponencial, tal modelo é posteriormente confirmado pelos resultados das simulações em Elementos Finitos.

Nota: foi opção do autor utilizar em alguns pontos do texto deste trabalho unidades comuns à indústria do petróleo brasileira, nem sempre seguindo o padrão do Sistema Internacional de Unidades.

\section{2. \\ Descrição de um sistema de testemunhagem padrão}

Embora existam ligeiras diferenças nos detalhes dos equipamentos utilizados por cada companhia prestadora de serviços de testemunhagem, o conceito geral do projeto é compartilhado entre elas, e permanece o mesmo há décadas.

O barrilete externo é rotacionado juntamente com a coluna de perfuração, e provê tal rotação à coroa de testemunhagem, broca com orifício central responsável por usinar a amostra cilíndrica de rocha. Internamente, outro tubo, concêntrico ao barrilete externo, permanece praticamente estacionário ao longo da operação, guiando em relativa segurança a amostra de rocha, e minimizando sua exposição ao fluxo do fluido de perfuração. Tal independência de movimento entre os tubos concêntricos só é possível graças a um conjunto de rolamentos posicionados na parte superior do barrilete interno, que permite que o tubo interno permaneça estacionário, solidário à amostra de testemunho, independente do movimento de rotação aplicado ao barrilete externo.

Ao longo da testemunhagem, o fluido de perfuração bombeado pelo interior da coluna, ao chegar ao conjunto de barriletes, é desviado para o espaço anular entre os tubos concêntricos. Após isso é descarregado pela garganta e portas da coroa, e então retorna pelo anular do poço. O fluido de perfuração, além de remover o cascalho gerado, é responsável por resfriar a coroa e contribuir para o corte do cilindro de rocha. No entanto, no caso de uma rocha muito frágil, a circulação do fluido, se excessiva, pode contribuir para a desagregação da amostra de rocha. 
A Figura 2.1 ilustra e numera os principais componentes do sistema de testemunhagem. Em seguida, uma explicação detalhada dos componentes do sistema de testemunhagem que permite ao leitor uma compreensão melhor, não apenas da função de cada componente, bem como do sistema de testemunhagem como um todo. Para uma melhor compreensão, se procurou retratar o sistema de testemunhagem de uma forma simples e geral, sem incorporar detalhes que remetam ao equipamento específico de uma determinada companhia de serviços.

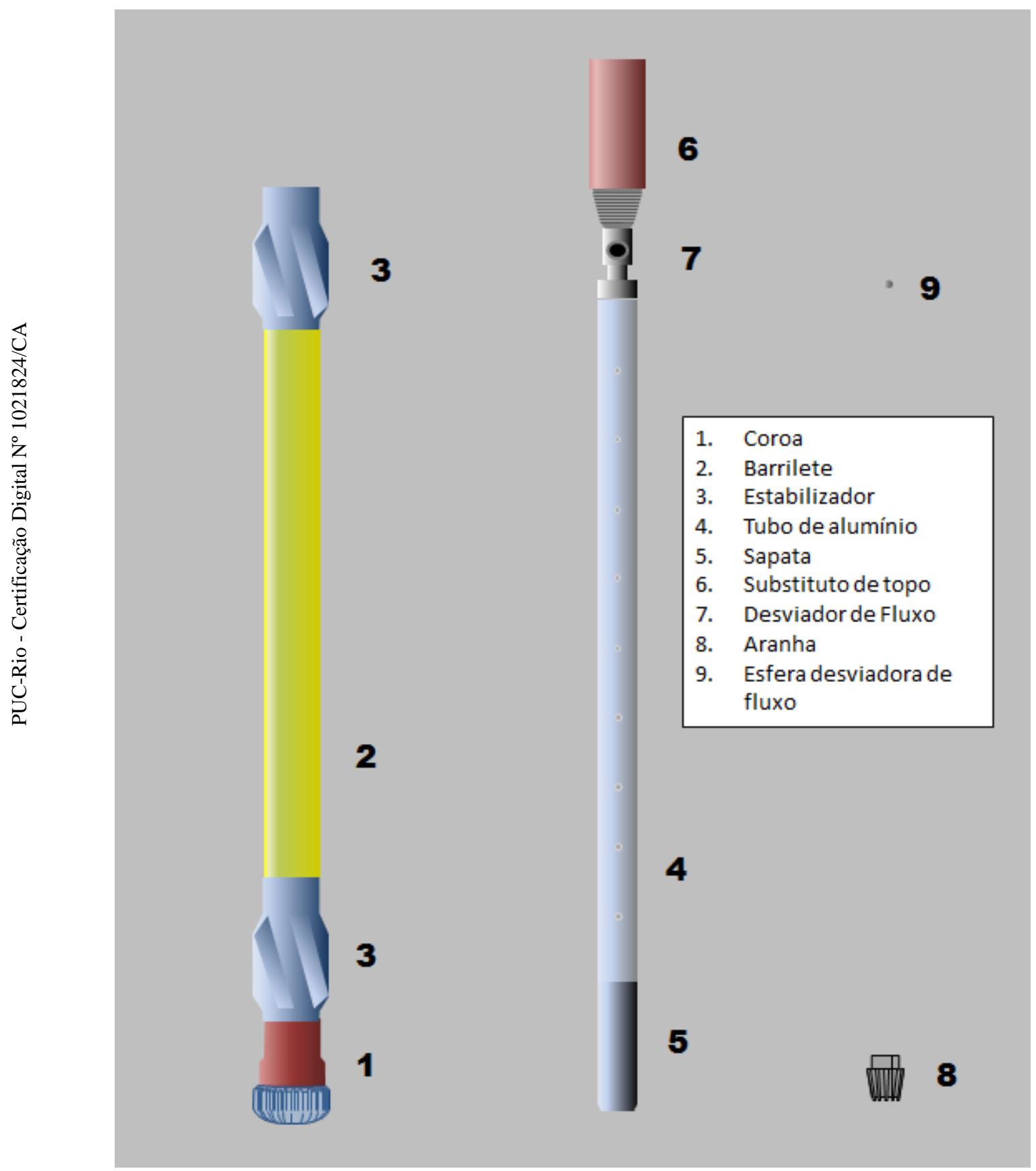

Figura 2.1: Desenho esquemático dos principais componentes em um sistema de testemunhagem padrão. 
1. Coroa: consiste na broca utilizada na testemunhagem. Com um orifício central, é responsável não apenas pela perfuração do poço, mas também pela usinagem do cilindro de rocha. Deve operar de maneira estável de forma a garantir a integridade e o diâmetro do testemunho. É classificada principalmente quanto ao seu elemento cortante (PDC, diamante natural, etc). A coroa de insertos de PDC (polycrystalline diamond compact) é atualmente o tipo mais comumente empregado em formações inconsolidadas. Os cortadores de PDC são compostos por uma estrutura de carbureto de tungstênio com sua face de corte sinterizada por uma película composta por diamantes sintéticos mesclados em uma liga metálica de modo a permitir sua adesão. A coroa de testemunhagem pode ser ainda classificada como throat discharge (descarga pela garganta) ou face discharge (descarga pela face). No primeiro caso, o fluxo ocorre totalmente, ou quase totalmente, através da garganta, próximo à amostra de testemunho. Desta forma, além de permitir uma apropriada remoção dos cascalhos e resfriamento da coroa, também auxilia a própria coroa no corte da amostra de rocha. No entanto, tal configuração pode ser prejudicial às rochas inconsolidadas, com potencial de causar a "lavagem" do testemunho, jargão que se refere à desagregação da rocha pela passagem do fluido. Para essas rochas passíveis de erosão, são então utilizadas coroas do tipo face discharge, que direcionam boa parte do fluxo (80 90\%) para portas na face da coroa, distanciando-o da amostra de testemunho. A Figura 2.2 apresenta uma coroa de PDC dotada de configuração face discharge. 


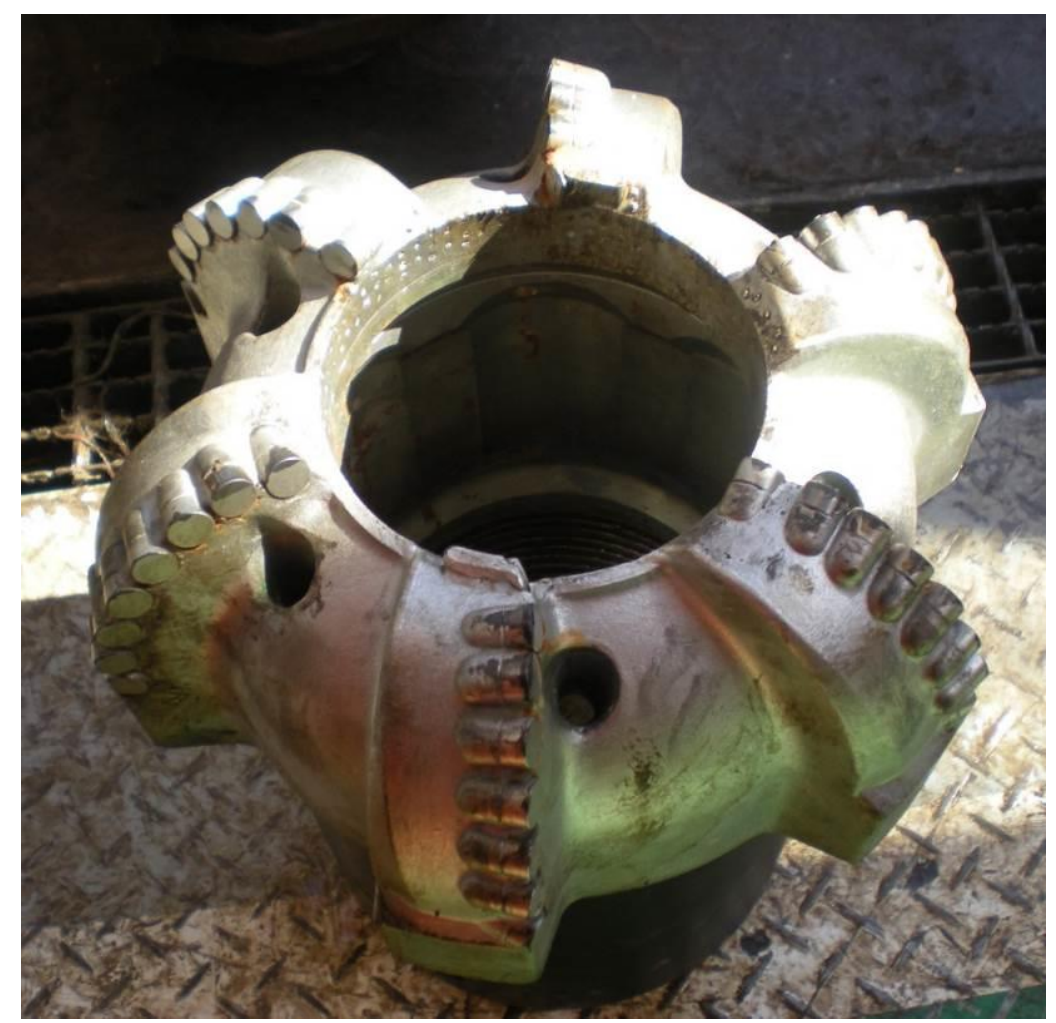

Figura 2.2: Coroa de insertos de PDC, apropriada para formações de baixa resistência, portas na face de ataque direcionam a maior parte do fluxo o distanciando da amostra de rocha (face discharge)

2. Barrilete: tubos externos de aço posicionados alternadamente com os estabilizadores. A quantidade de barriletes utilizados dependerá da extensão de testemunho que se pretende recuperar em uma manobra de uma operação de testemunhagem. A maioria das companhias de testemunhagem utiliza o conjunto barrilete/estabilizador com um comprimento total de $30 \mathrm{ft}(9,14 \mathrm{~m})$, embora haja companhia que utilize conjunto de $20 \mathrm{ft}$ (6,09 m). Desta forma o comprimento total máximo passível de ser recuperado em cada descida é um múltiplo desses valores. Rochas mais resistentes permitem a utilização de um número maior de barriletes, aumentando a extensão recuperada por descida.

3. Estabilizadores: responsáveis por manter a coroa e o barrilete centralizados permitindo a efetiva usinagem do cilindro de rocha. Além disso, uma boa estabilização é necessária de modo a evitar o rompimento por fadiga ou desconexão das conexões do barrilete, não tão robustas por se tratar de um tubo com grande diâmetro e reduzida espessura de parede. Os estabilizadores do 
barrilete possuem diâmetro ligeiramente menor que o diâmetro da coroa (tipicamente $1 / 32$ in menor).

4. Tubos internos: responsáveis pelo acondicionamento do testemunho. Em geral compostos de liga de alumínio. Possuem válvulas de alívio ou outros dispositivos que permitam a drenagem do gás que exuda do testemunho durante a manobra de retirada. Após a testemunhagem são sacados e seccionados juntamente com a amostra de rocha em seções de $90 \mathrm{~cm}$. Cada seção é então tamponada e enviada para o laboratório de geologia. Uma vez que a expansão térmica do alumínio é superior à do aço (material do barrilete), antes da operação deve ser realizado um ajuste do espaçamento entre a extremidade da sapata e o ombro interno da coroa, de acordo com a deformação diferencial proporcional a temperatura prevista na profundidade da testemunhagem.

5. Sapata: elemento conectado à extremidade inferior da coluna de tubos internos. Tem como principal função servir de alojador para a aranha, elemento responsável pelo rompimento e retenção da amostra de testemunho dentro do tubo interno. Feita de aço, possui ainda a função de conferir resistência à extremidade da coluna contra a erosão provocada pelo fluido de perfuração ao passar pelo estrangulamento entre a sapata e ombro interno da coroa de testemunhagem. Quando a testemunhagem é orientada (para a orientação espacial da amostra), a sapata possui facas internas que marcam longitudinalmente a amostra de testemunho, servindo como referências de orientação.

6. Substituto de topo ou conjunto superior: elemento superior do sistema de testemunhagem. Suporta internamente a coluna de tubos internos. Na maioria dos casos contém dispositivo de ajuste de elevação do tubo interno, alterando o espaçamento entre a sapata e o ombro interno da coroa de acordo com o montante requerido para acomodar a expansão térmica dos tubos internos. O subtituto de topo é responsável ainda por converter a conexão especial do barrilete na conexão comumente utilizada na coluna de perfuração. 
7. Desviador de fluxo e rolamentos: o desviador de fluxo possui internamente uma sede para assentamento de uma esfera (ver Figura 2.3). Ao chegar ao fundo do poço, antes de iniciar a testemunhagem, é efetuada uma circulação de fluido através do interior do barrilete para permitir a limpeza de seu interior. Após essa circulação é lançada e bombeada através do interior da coluna uma esfera de aço que, ao atingir a sede, desvia o fluxo do fluido de perfuração para o anular entre o tubo interno e o barrilete, cessando o fluxo pelo interior do tubo interno. De outra forma o fluxo seria forçado sobre a amostra, possivelmente a danificando e estimulando a invasão de fluidos em seus poros. Os rolamentos permitem os tubos internos permanecerem estacionários, solidários ao testemunho e ao fundo do poço. Embora neste exemplo tenham sido retratados dispostos de forma conjunta, o posicionamento exato de ambos os componentes varia ligeiramente dependendo da companhia. 


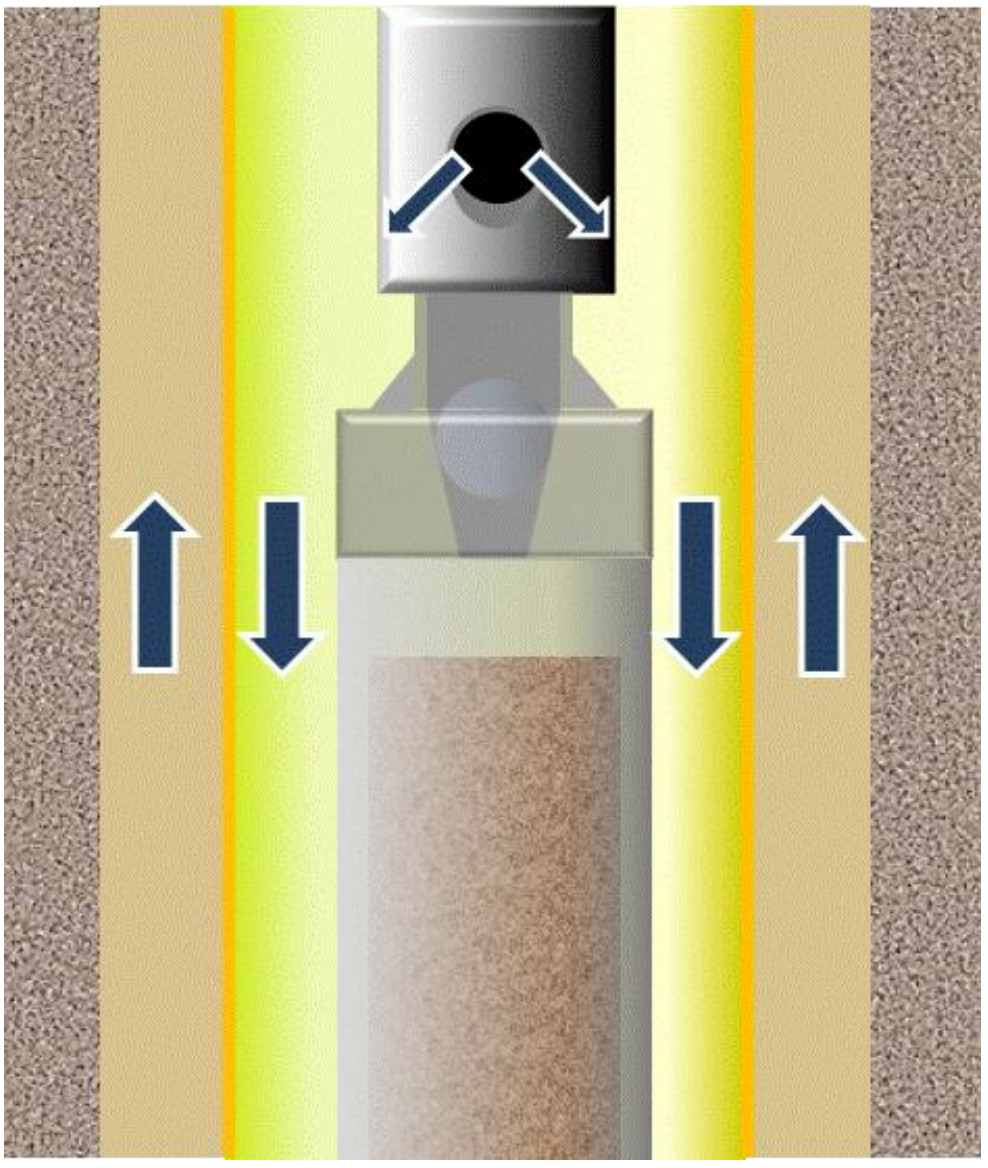

Figura 2.3: Desvio do fluxo para o anular entre os tubos externo e interno após o assentamento da esfera

8. Aranha (core catcher): dispositivo em forma de cunha circular responsável pela retenção e rompimento da amostra de testemunho (Figura 2.4). Um rasgo provê ao componente certa elasticidade, e sua superfície interna é rugosa, permitindo aderência à superfície do cilindro de rocha. A aranha é encaixada em um perfil cônico no interior da sapata. Enquanto o testemunho entra no barrilete a aranha permanece na posição aberta, entretanto quando se retira a coroa do fundo do poço, subindo o barrilete, a aranha tende a fechar, agarrando o testemunho e permitindo sua recuperação. Rochas inconsolidadas ou friáveis possuem considerável risco em deslizar através da aranha, desta forma as companhias de testemunhagem apresentam como opção sistemas de retenção alternativos que, usados de forma concomitante com a aranha, maximizam a chance de recuperação da amostra. 


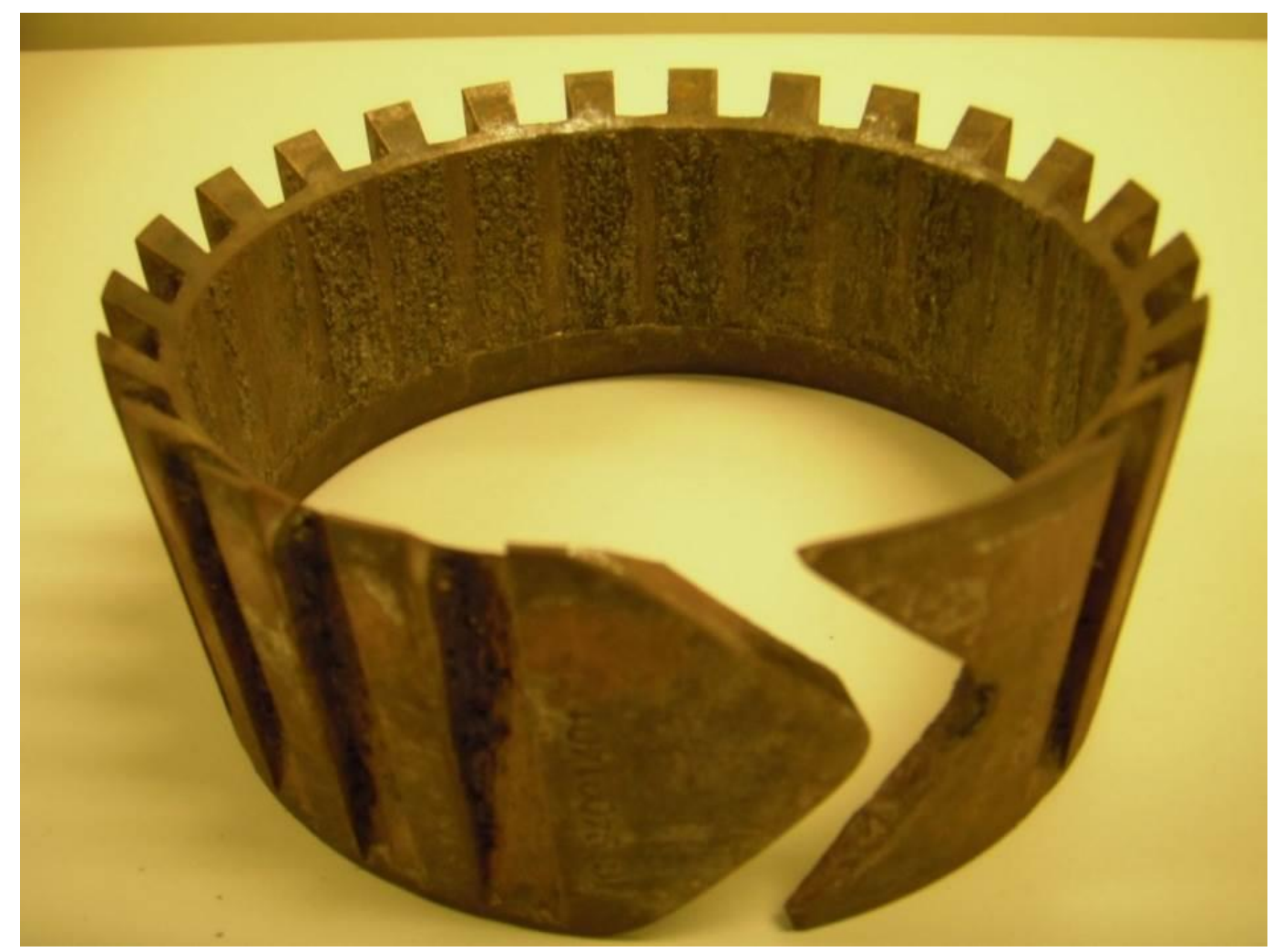

Figura 2.4: Aranha, componente responsável pela retenção da amostra de testemunho

9. Esfera desviadora de fluxo: lançada antes do início da testemunhagem, tampona o fluxo pelo interior do barrilete, o desviando para o anular entre o tubo interno e o barrilete externo.

\section{3. \\ O acunhamento em linhas gerais}

$\mathrm{Na}$ atividade de testemunhagem, denomina-se acunhamento quando, devido ao atrito, o testemunho para de penetrar no interior do tubo interno. O mecanismo do acunhamento depende das características da formação testemunhada e, apesar da semântica, nem sempre está associado à presença de fragmentos de rocha em forma de cunhas. Em alguns casos o fenômeno seria mais corretamente descrito como uma embolia, "embuchamento" ou obliteração. Entretanto, por simplicidade, manteve-se o mesmo termo.

É possível então relacionar o acunhamento com três tipos de mecanismos: 
1. Acunhamento em rochas com fraturas naturais ou induzidas;

2. Acunhamento em rochas inconsolidadas;

3. Acunhamento em formações expansivas.

$\mathrm{O}$ acunhamento do tipo 1 (Figura 2.5, 2.6 e 2.7) é o que poderia ser chamado de acunhamento clássico, pois nele os fragmentos da rocha agem uns sobre os outros como cunhas, aumentando o arraste da amostra ao se deslocar através do interior do tubo de alumínio que a envolve.

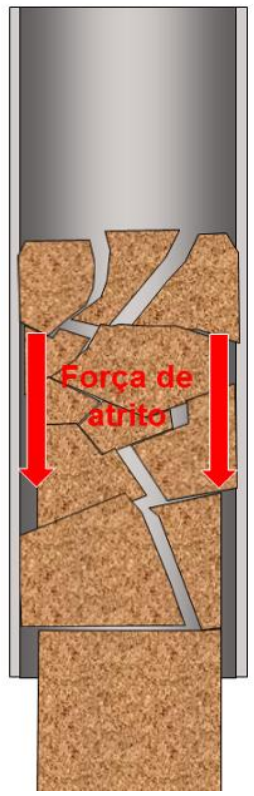

Figura 2.5: Acunhamento do tipo 1, típico em testemunhos com fraturas naturais ou induzidas 


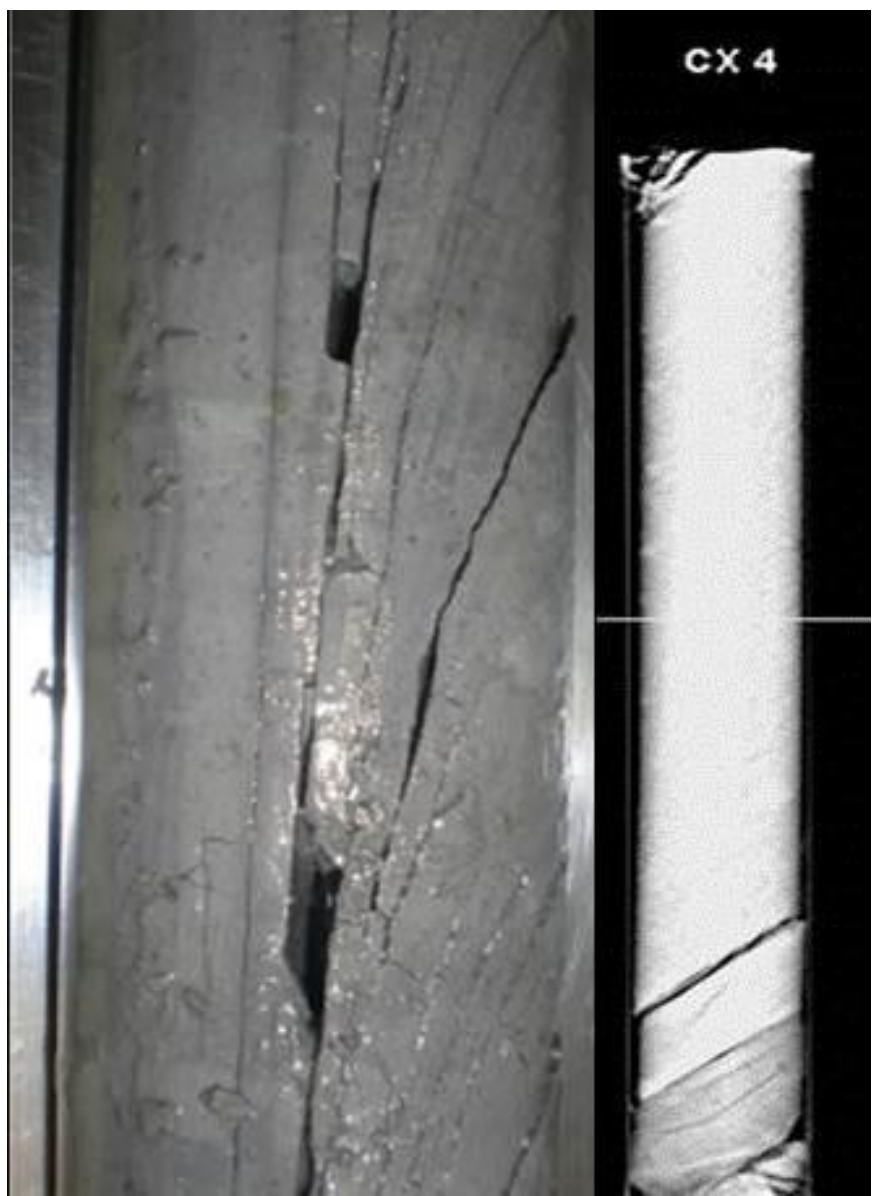

Figura 2.6: Exemplos de fraturas induzidas capazes de provocar o acunhamento [4] 


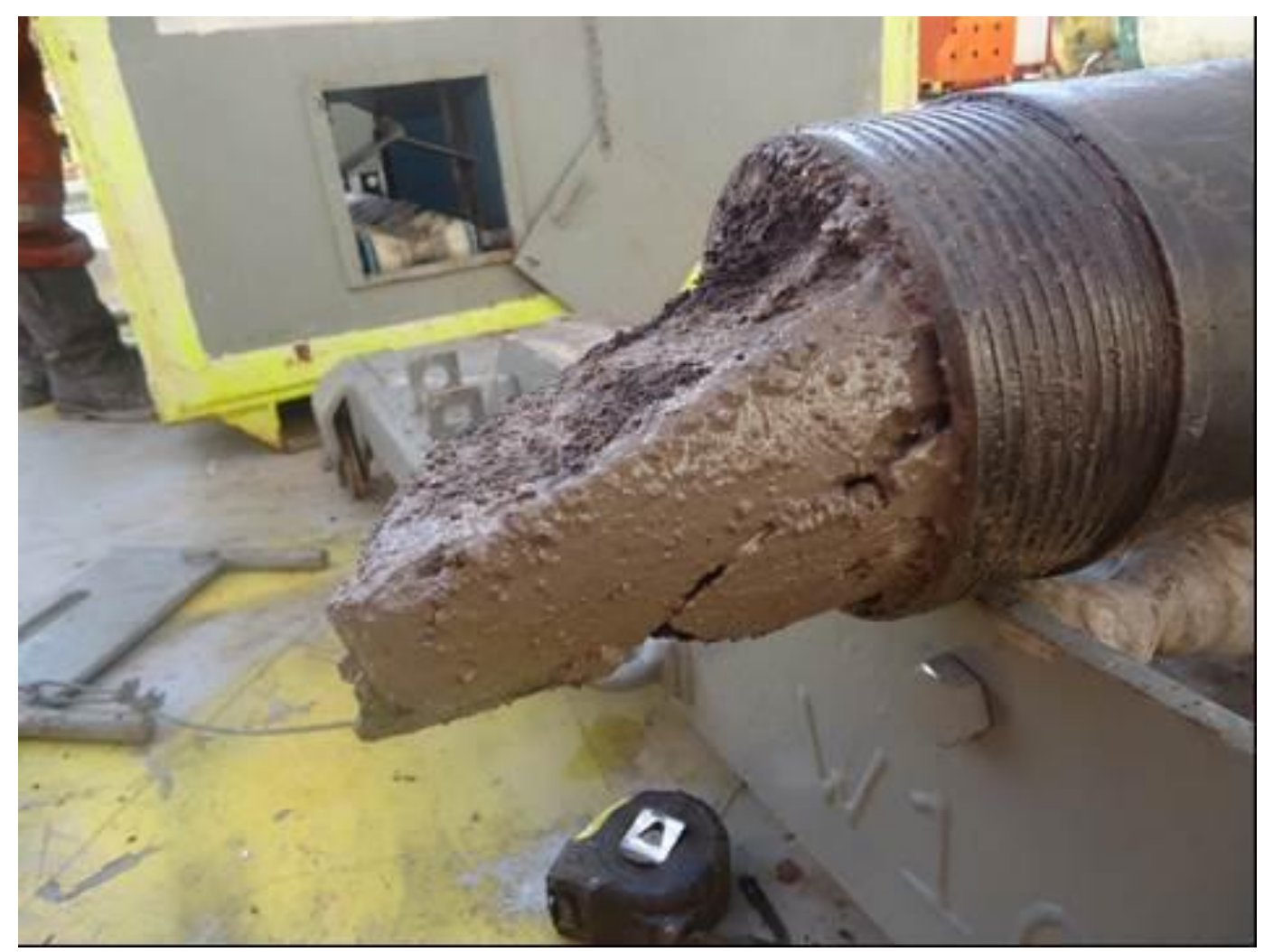

Figura 2.7: Acunhamento do testemunho que na impossibilidade de prosseguir adentrando o barrilete fraturou próximo à sua base

No acunhamento do tipo 1 a rocha pode ser resistente o suficiente para suportar o esforço ao qual está sujeita após o acunhamento. Sendo assim, o acunhamento é mais facilmente evidenciado na superfície, pois o avanço da testemunhagem cessa e o torque e a pressão caem, uma vez que a coroa (broca) de testemunhagem deixa de estar intimamente em contato com o fundo do poço. O peso antes aplicado sobre a broca passa a ser suportado pela coluna de testemunho.

O acunhamento do tipo 1 é de ocorrência mais imprevisível pois está associado à presença de fraturas e suas características.

O acunhamento do tipo 2 (Figura 2.8) está relacionado à testemunhagem em formações inconsolidadas. Tal fenômeno ocorre devido à desagregação parcial do testemunho em função da vibração do barrilete durante a testemunhagem, ou até mesmo devido à relaxação da amostra pelo alívio das tensões. Os sedimentos desagregados da parte superior decantam por gravidade e preenchem o pequeno espaço anular entre a amostra e o tubo de alumínio, aumentando o atrito entre ambos. 


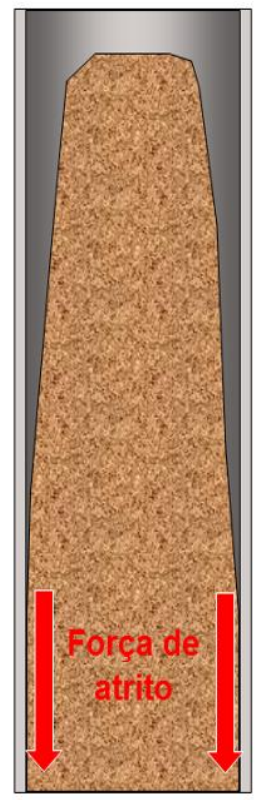

Figura 2.8: Acunhamento do tipo 2, em formações inconsolidadas; desagregação parcial da rocha preenche o espaço entre a amostra de rocha e o tubo

Isso significa que no transcorrer da testemunhagem, a parte inferior do cilindro de rocha que está sendo usinado está sujeito a uma compressão cada vez maior, uma vez que deve suportar não apenas o peso de toda a coluna de testemunho, mas também deve superar o esforço necessário para a amostra prosseguir penetrando o tubo de alumínio. Como tais rochas possuem baixa resistência ao cisalhamento, existe um comprimento máximo que cada rocha inconsolidada permite ser testemunhada. Após esse ponto a base do cilindro de rocha colapsa e a rocha passa a ser destruída. A baixa resistência da rocha faz também com que os sintomas do acunhamento não sejam claramente perceptíveis em superfície. Nesse caso a coroa de testemunhagem permanece em contato com o fundo e passa a funcionar como uma broca. A rocha frágil é facilmente removida, não apenas pelo trabalho mecânico da coroa, mas também pela circulação do fluido de perfuração. Há casos de arenitos muito frágeis que acunham com apenas um ou dois metros cortados, restando ao supervisor da operação limitar o comprimento da barriletada a esse valor, de modo a minimizar a perda de parte da formação alvo. 
O terceiro tipo de acunhamento ocorre quando se testemunha formações com tendência a expandir. Principalmente argilas do grupo das esmectitas (como a montmorilonita) que reagem com o fluido de perfuração base água. Quando a testemunhagem inicia ainda no folhelho capeador ou quando se testemunha trechos com intercalações há uma preocupação quando se passa da argila para o arenito, pois este último, sendo frágil, pode não ter resistência de empurrar a argila expansiva barrilete adentro.

Conforme previamente descrito na introdução, o trabalho proposto aborda o problema do acunhamento do tipo 2, típico de formações inconsolidadas. A atividade exploratória no Brasil nos últimos anos está voltada principalmente a carbonatos consolidados, com as descobertas na última década na camada pré-sal. Desta forma haveria também uma motivação muito grande em estudar o acunhamento do tipo 1, único a ocorrer neste tipo de formação. Entretanto, embora indesejável por atrasar o cronograma da operação, o acunhamento do tipo 1 em geral não costuma causar a perda do testemunho. Adicionalmente, estando a ocorrência de tal acunhamento associada a alguns fatores considerados imponderáveis na prática, como a presença de fraturas e suas características, a sua ocorrência é de previsão muito mais difícil. Desta forma, para o acunhamento do tipo 1 especificamente a motivação de tal estudo estaria voltada ao desenvolvimento ou avaliação de técnicas ou tecnologias de prevenção, e não à previsão do acunhamento.

\section{4.}

\section{Parâmetros determinantes na ocorrência do acunhamento}

Variáveis de diversas naturezas devem ser consideradas na análise do potencial para a ocorrência do acunhamento. Pode-se dividir em três categorias principais.

A primeira consiste nas características intrínsecas da própria rocha a ser testemunhada. Conforme já explicado anteriormente, a resistência da rocha, a presença de fraturas ou sua deformação durante o corte são fatores que inevitavelmente influenciam no arraste da amostra em relação ao tubo interno que a envolve e consequentemente na ocorrência do acunhamento. 
A segunda classe são os aspectos operacionais e ambientais. Os parâmetros de perfuração utilizados durante a testemunhagem podem maximizar a vibração no barrilete desestabilizando a amostra de testemunho e aumentando o risco de acunhamento. Simuladores numéricos e sistemas de medição do nível de vibração nos equipamentos durante a perfuração mostram que, dependendo da rotação e do peso sobre a broca, o nível de vibração pode subir drasticamente devido à ressonância.

Um mau funcionamento do sistema de compensação de movimentos da sonda e/ou uma condição de mar extrema pode causar grande oscilação no peso aplicado sobre a coroa (broca) de testemunhagem causando a desestabilização da amostra de forma semelhante à mencionada no parágrafo anterior. Esta anomalia também pode contribuir para a geração e propagação de fraturas na amostra, além de possivelmente usinar um cilindro imperfeito devido a inconstância dos parâmetros.

Há ainda a influência do tipo de fluido de perfuração que, dependendo de sua natureza (base água, óleo ou sintético), apresenta diferentes níveis de lubricidade, interferindo no arraste entre a amostra e o tubo. Adicionamente, caso haja interação físico-química entre o fluido e rochas quimicamente ativas (argilas) pode ocorrer a expansão dessas últimas, causando o acunhamento do tipo 3.

Por fim, a terceira classe consiste nas características do sistema de testemunhagem utilizado, incluindo sua dimensão e o diâmetro da amostra gerada.

Características dos sistemas de testemunhagem, desde o projeto da coroa (broca), passando pelo conjunto de rolamentos e espessura do tubo de alumínio, podem influenciar tanto no nível de vibração quanto no arraste da amostra no interior do barrilete.

Coroas com insertos de PDC, por exemplo, indicadas para formações friáveis como o arenito, podem ser mais ou menos agressivas, dependendo do número de aletas. Coroas de PDC com menos aletas tendem a ser mais agressivas, promovendo uma maior taxa de penetração. Em compensação, geram, em teoria, um nível maior de vibração.

Hoje em dia, há principalmente duas opções de tamanho disponíveis no mercado. Sistemas com coroa de testemunhagem com diâmetro de 12 1/4 e 8 1/2 polegadas, que cortam testemunhos de $5 \frac{1}{4} 4$ e 4 polegadas, respectivamente. Por experiência, alguns profissionais que trabalham com testemunhagem observam 
alguma correspondência entre o diâmetro do sistema de testemunhagem (e consequentemente o diâmetro da amostra gerada) e a ocorrência do acunhamento. Exemplificando, nas testemunhagens no carbonato do pré-sal do Brasil já se conseguiu testemunhar e recuperar cerca de $67 \mathrm{~m}$ de testemunho em uma única manobra, utilizando o sistema de maior diâmetro (12 1/4 in). No entanto, com o sistema de $8 \frac{1}{2}$ in essa marca nunca ultrapassou os $36 \mathrm{~m}$.

Outro aspecto importante a ser considerado no estudo do acunhamento é a resistência exercida pelo fluido sobre o topo do testemunho. À medida que o testemunho penetra no interior do barrilete, ele preenche um espaço inicialmente ocupado pelo fluido de perfuração. Enquanto existente o pequeno anular entre a amostra de rocha e o tubo de alumínio o fluido tem esse caminho por onde retornar. No entanto, uma vez que a amostra de rocha desagregada tenha obliterado plenamente o espaço anular rocha-tubo, restam somente dois caminhos para a drenagem da pressão trapeada no tubo interno.

A primeira delas é ser drenado pelas pequenas válvulas de esfera instaladas na parede do tubo. Essas válvulas permitem um fluxo unidirecional do interior para o exterior do tubo e têm a função de possibilitar a drenagem da pressão no seu interior na medida em que o sistema é trazido à superfície, tornando mais segura a desmontagem e recuperação da amostra. No entanto, essas válvulas possuem diâmetro diminuto, são destinadas principalmente à drenagem dos hidrocarbonetos em estado gasoso. No caso de um fluido viscoso a passagem ocorre a uma taxa muito lenta.

Outra opção é a de o aumento da pressão na câmara sobre o testemunho desassentar a esfera que desvia o fluxo (Figura 2.3). A esfera é mantida em sua sede pela força-peso e principalmente pela pressão de bombeio que atua sobre ela. Quando a pressão no interior do tubo de alumínio aumentar o suficiente para desalojar a esfera, o fluido pode então ser drenado para a câmara sobre a esfera e levado pela circulação. Então desta forma, pode-se dizer que a pressão exercida pelo fluido sobre a amostra de testemunho está limitada aproximadamente pelo diferencial de pressão atuante sobre a esfera.

Analisando o caminho percorrido pelo fluido, explicado no sub-capítulo 2.2, conclui-se que o diferencial de pressão sobre a esfera consiste em aproximadamente a soma das perdas de carga nos orifícios de desvio do fluxo (Figura 2.3) e no anular entre o tubo de alumínio e o barrilete externo. 
Para o cálculo da perda de carga nos orifícios pode-se utilizar a equação comumente adotada para jatos de brocas [32]:

$$
P=\frac{M W \cdot Q^{2}}{12032 \cdot\left(C_{d}\right)^{2} \cdot\left(A_{j}\right)^{2}}
$$

Onde:

- $\quad \mathrm{P}$ : perda de carga no jato (psi);

- MW : densidade do fluido de perfuração (lb/gal);

- Q : vazão (gpm);

- $\mathrm{A}_{\mathrm{j}}$ : área dos jatos $\left(\mathrm{in}^{2}\right)$;

- $\mathrm{C}_{\mathrm{d}}$ : coeficiente dos jatos, sugerido por Robinson [32] como 1,03 .

\section{5 .}

\section{Como as companhias de serviço de testemunhagem tratam o acunhamento}

O acunhamento da amostra de testemunho (core jamming) é, há algumas décadas, uma preocupação constante do profissional, e também das companhias que prestam o serviço de testemunhagem (coring). Podendo ser afirmado que a companhia que disponha de uma solução eficaz para tal problema possuiria um diferencial competitivo muito grande no mercado, uma vez que para os clientes, as operadoras do ramo de petróleo e gás, a ocorrência do acunhamento acarreta prejuízos substanciais, conforme já explanado anteriormente. Estaria desta forma o cliente disposto a pagar mais por tal diferencial tecnológico. Além disso, a redução do custo da testemunhagem, de uma maneira geral, poderia contribuir para que tal operação fosse realizada com uma maior frequência, aumentando a demanda por tal serviço. 
Desta forma, é natural que tais companhias tenham buscado com o passar dos anos, rever seus procedimentos e desenvolver produtos alternativos, com o intuito de, não sendo possível eliminar completamente, ao menos diminuir consideravelmente a incidência de acunhamentos.

Os cuidados nos procedimentos estão, em geral, relacionados à tentativa de manter um menor nível de vibração no barrilete de testemunhagem durante a operação. A vibração está intimamente relacionada com a ocorrência de acunhamento, pois pode desestabilizar ou estimular fraturas na amostra de testemunho, facilitando a obliteração do tubo interno. Sendo assim, é necessária uma atenção aos parâmetros de perfuração (peso sobre broca, rotação, torque) de modo a manter o corte do cilindro de rocha de forma mais estável quanto possível.

As companhias de testemunhagem trabalham em diferentes linhas de ação ao projetar produtos com a pretensão de minimizar o acunhamento. Algumas das linhas também atuam na diminuição da vibração, como por exemplo o projeto de coroas de testemunhagem que permitam um equilíbrio entre uma taxa de perfuração razoável e um corte mais estável.

Determinada companhia desenvolveu um tubo de alumínio com sua superfície interna polida e coberta com uma película de um material que lhe provê baixo coeficiente de atrito rocha-tubo. Tal tubo de alumínio é bipartido longitudinalmente. Possivelmente uma necessidade construtiva de modo a facilitar a aplicação da película redutora de atrito na parede interna do tubo.

Outra via de ação é a melhoria do sistema de rolamentos, que permitem que o barrilete interno permaneça estacionário, solidário ao testemunho, enquanto o barrilete externo rotaciona juntamente com a coroa de testemunhagem. Tal melhoria pode permitir uma maior estabilidade, evitando a introdução de esforços torsionais que possam desestabilizar a amostra de rocha. Além disso, um rolamento com menor atrito minimiza um esforço torsional sobre a amostra de testemunho. Tal melhoria é buscada de diferentes maneiras. Através da redundância, com a adoção de um número maior de rolamentos e uma distribuição maior dos esforços entre eles. Com um projeto mais apurado, de rolamentos cônicos e utilizando roletes no lugar de esferas. Ou até mesmo com rolamentos selados, onde as esferas não têm contato com o fluido de perfuração e com seus sólidos em suspensão. 
Determinada companhia desenvolveu um sistema muito particular de lidar com o acunhamento. Trata-se de um tubo de alumínio telescópico, como uma antiga antena de televisão. Ao início da testemunhagem o tubo permanece fechado, com as camisas posicionadas de forma concêntrica. À medida que o testemunho adentra no tubo, uma vez ocorrido o acunhamento, a amostra de testemunho empurra a primeira camisa para cima. Depois de aplicado esforço suficiente para o cisalhamento de um pino que mantém a camisa na posição, a segunda camisa começa a ser exposta, à medida em que a primeira é deslocada. Tal idéia, embora criativa, limita esta solução ao acunhamento do tipo 1, já que no acunhamento em formações inconsolidadas dificilmente a rocha possuirá resistência suficiente para cisalhar o pino e deslocar a camisa. Além disso, o sistema apresenta solução para os acunhamentos até que se esgote o número de camisas, que não podem ser muitas sem que se necessite diminuir o diâmetro do testemunho gerado por mera falta de espaço.

Por fim, há no mercado um barrilete de testemunhagem instrumentado, que mede os esforços no barrilete interno, assim como temperatura e pressão dentro e fora do barrilete. No entanto, no estágio atual de desenvolvimento tal equipamento não disponibiliza tais informações na superfície, em tempo real, sendo desta forma somente um aliado em identificar post-mortem e analisar a anomalia que ocorreu durante a operação de testemunhagem. Tal informação tem sua serventia pelo menos como uma referência para o operador de testemunhagem tentar algo diferente, que impeça que o problema volte a ocorrer, mas a tecnologia poderá ser considerada realmente um grande avanço na área quando finalmente permitir ao operador identificar o acunhamento assim que ele ocorra. Tal feito não evitaria o acunhamento em si, mas evitaria a perda de testemunho e a perda de tempo provocado pelo acunhamento.

Em suma, fica bem claro que o acunhamento é uma preocupação das companhias de testemunhagem, embora nenhuma delas possua uma solução definitiva para o problema. 


\section{6. \\ 0 contato entre superfícies e 0 atrito}

Denomina-se atrito como a força de resistência que se opõe ao movimento relativo de deslizamento entre duas superfícies ou camadas de fluido. Quando duas superfícies em contato deslizam uma em relação a outra, o atrito entre elas provocado pela rugosidade transforma parte da energia cinética em calor. Este fenômeno é o que permite a geração de fogo a partir da fricção de dois pedaços de madeira.

O atrito faz parte da tribologia, ciência que estuda a interação de superfícies em movimento relativo. Além dos princípios do atrito, a tribologia estuda também a lubrificação e o desgaste entre as superfícies em movimento.

A força de atrito é sempre paralela às superfícies em interação e contrária ao movimento relativo entre eles. No entanto, apesar de paralelo às superfícies em interação, o atrito entre estas superfícies depende diretamente da força normal, a componente da força de contato perpendicular às superfícies.

O atrito não é uma força fundamental, originando-se a partir da combinação de: aderência, rugosidade, deformação e contaminação das superfícies em contato $[8]$.

\subsection{1.}

\section{O modelo de Coulomb}

O modelo mais simples, e também o mais clássico, é o modelo de atrito de Coulomb. Nele o movimento tangencial entre as superfícies tem início quando a força cisalhante ultrapassa um valor crítico, proporcional à força normal exercida entre as superfícies, de acordo com a seguinte equação:

$$
\mathrm{F}_{\text {atest }}=\mu_{\text {est }} \cdot \mathrm{N}
$$

Onde $F_{\text {at est }}$ denomina-se força de atrito estático, $\mu_{\text {est }}$ é o coeficiente de atrito estático e $\mathrm{N}$ a força normal. 
Uma vez estabelecido o movimento entre as superfícies a força necessária para mantê-lo é menor que a força máxima aplicada para iniciá-lo $\left(F_{a t}\right.$ est $>F_{a t}$ din $)$. Desta forma pode-se concluir que o coeficiente de atrito dinâmico é menor do que o estático $\left(\mu_{\text {est }}>\mu_{\text {din }}\right)$.

$$
\mathrm{F}_{\text {at din }}=\mu_{\text {din }} \cdot \mathrm{N}
$$

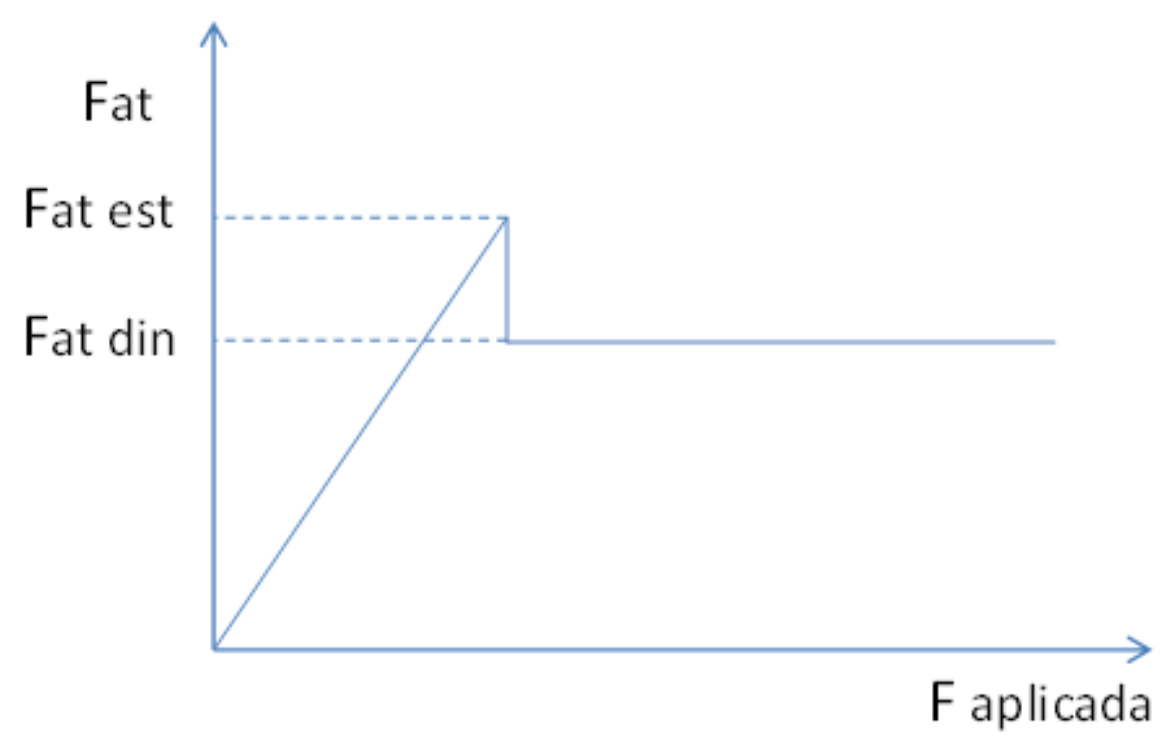

Figura 2.9: Representação do modelo de Coulomb

Ruina e Pratap [27] listam as seguintes vantagens e desvantagens para o modelo de atrito de Coulomb:

Vantagens:

1. O modelo de Coulomb é simples;

2. O modelo satisfaz a reprodução de muitos fenômenos;

3. Ele apresenta a tendência correta em muitos aspectos como: o atrito de deslizamento é de maneira geral independente da taxa de deslizamento, a força de atrito é de maneira geral proporcional à força normal;

4. Os demais modelos costumam acarretar um acréscimo de complexidade maior que o eventual ganho em exatidão.

Desvantagens: 
1. O coeficiente de atrito não é estável, pode variar dia após dia ou entre amostras diferentes de um mesmo material;

2. A lei de Coulomb não é capaz de representar integralmente alguns fenômenos como: o ranger de portas, excitação provocada pelo arco na corda de um violino e terremotos provocados pelo deslizamento das rochas em uma falha;

3. Para alguns materiais a relação entre a força de atrito e a força normal está longe de ser linear, como por exemplo a borracha de um pneu sobre a estrada quando a relação é maior para níveis menores de tensão normal. Isso explica o porquê dos automóveis esportivos ou de competição terem rodas maiores e mais largas, quando a área de contato maior implica em uma menor tensão normal.

\subsection{2. \\ O plano inclinado}

Um exemplo acadêmico clássico para explicar os princípios do atrito é o plano inclinado (Figura 2.10) estabelecido por Leonard Euler (1707-1783).

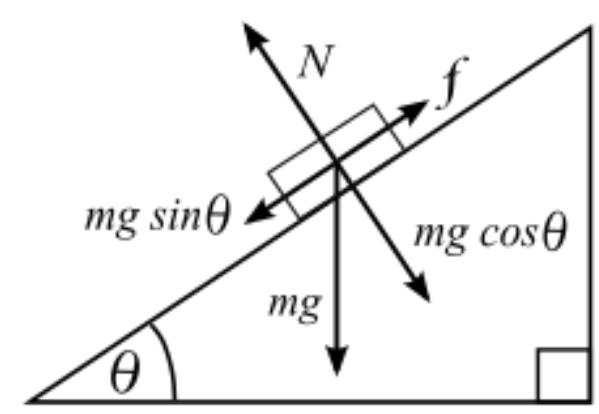

Figura 2.10: Bloco no plano inclinado, exemplo acadêmico clássico para explicar os princípios da força de atrito [8]

Nele um bloco de massa m é posicionado sobre uma superfície com determinada inclinação em relação à horizontal $(\theta)$. A força peso $(\mathrm{mg})$ pode ser dividida em duas componentes: uma perpendicular $(m g \cdot \cos (\theta))$ e outra paralela às superfícies em contato $(\mathrm{mg} \cdot \operatorname{sen}(\theta))$. Enquanto a primeira origina a força de contato N, a segunda possui a tendência de movimentar o bloco rampa abaixo. As equações 2.4 e 2.5 representam o equilíbrio de forças nesse exemplo. 


$$
\begin{aligned}
& \mu=\operatorname{tg}(\theta)-\frac{(\mathrm{mg} \cdot \operatorname{sen}(\theta)-\mathrm{f})}{\mathrm{mg} \cdot \cos (\theta)} \\
& \mu=\frac{\mathrm{mg} \cdot \operatorname{sen}(\theta)-(\mathrm{mg} \cdot \operatorname{sen}(\theta)-\mathrm{f})}{\mathrm{mg} \cdot \cos (\theta)}
\end{aligned}
$$

No entanto, o movimento se estabelece somente quando esta última força ultrapassar o atrito estático: mg.sen $(\theta)>\mathrm{f}$.

O limiar para o início do movimento acontece quando mg.sen $(\theta)=\mathrm{f}$ e determina o coeficiente de atrito estático $\mu_{\text {est. Então: }}$

$$
\operatorname{mg} \cdot \operatorname{sen}(\theta)=\mu_{e s t} \cdot m g \cdot \cos (\theta)
$$

Os fundamentos de tal exemplo servem como subsídios para a construção de um simples experimento de plano inclinado (tilt test), para determinação do coeficiente de atrito estático entre duas superfícies. Nesse experimento o bloco é posicionado sobre uma superfície inicialmente na horizontal. A superfície é então gradativamente inclinada até o ponto em que se estabeleça o movimento do bloco. O coeficiente de atrito estático $\left(\mu_{\text {est }}\right)$ se relaciona com esta inclinação $(\theta)$ na forma:

$$
\mu_{\text {est }}=\operatorname{tg}(\theta)
$$

\section{7. \\ Modelagem analítica inicial}

Em pesquisa bibliográfica não foram encontrados estudos equivalentes ao que está sendo proposto. $\mathrm{O}$ acunhamento é abordado em alguns poucos artigos através de estudos de caso que focam principalmente a avaliação qualitativa de equipamentos que minimizam ou retardam a ocorrência do acunhamento. Em 
muitos dos casos, tais artigos são inclusive escritos por membros das companhias de serviço, e possuem desta forma um viés de propaganda de determinado equipamento.

A exceção é o trabalho realizado por uma equipe da Petrobras e divulgado em evento interno da companhia [3], que pela primeira vez estabeleceu um modelo de previsão da ocorrência do acunhamento em função da resistência prevista para a rocha a ser testemunhada.

Os autores propuseram um modelo para a previsão do comprimento a ser testemunhado em formações inconsolidadas. Para esse objetivo fizeram o cruzamento de dois modelos: o do acunhamento em si, quando a rocha cessa a penetração no interior do barrilete devido à fricção; e do cisalhamento, quando o trecho de rocha não confinada pelo tubo interno atinge seu limite de ruptura.

\subsubsection{Modelo Analítico do Acunhamento}

$\mathrm{O}$ acunhamento ocorre no momento em que a força de atrito $\left(\mathrm{F}_{\mathrm{at}}\right)$ atinge valor equivalente à força responsável pela entrada da amostra de rocha no interior do barrilete. Pode-se dizer que esta última força é equivalente ao peso sobre broca (WOB).

Então:

$$
\mathrm{F}_{\mathrm{at}}=\mathrm{WOB}
$$

Sabe-se que força de atrito é o produto do coeficiente de atrito entre os dois materiais $(\mu)$ e a força normal $(\mathrm{N})$.

$$
F_{\text {at }} \leq \mu . N
$$

Neste caso a força de atrito independeria da área de contato. Entretanto, no caso prático, ao invés de se dispor de uma força normal, dispõe-se sim de uma tensão normal, requerendo então a incorporação da área à equação. 
$\mathrm{F}_{\mathrm{at}} \leq \mu \cdot \sigma_{\mathrm{N}} \cdot A$

onde A é a area de contato entre a parede interna do tubo de alumínio e a amostra de testemunho. Assim:

$$
\mathrm{F}_{\mathrm{at}} \leq \mu \cdot \sigma_{\mathrm{N}} \cdot \mathrm{L} \cdot \pi \cdot \mathrm{D}
$$

Onde:

\author{
WOB: peso sobre broca [lb] \\ $\mu$ : coeficiente de atrito entre a amostra e o tubo de alumínio \\ $\sigma_{\mathrm{N}}$ : tensão normal à superfície do tubo exercida pela \\ amostra $\left[\mathrm{lbf} / \mathrm{in}^{2}\right]$ \\ D: diâmetro interno do tubo de alumínio [in]
}

A Figura 2.11 mostra, esquematicamente, o carregamento atuante sobre a amostra de rocha durante uma operação de testemunhagem. 


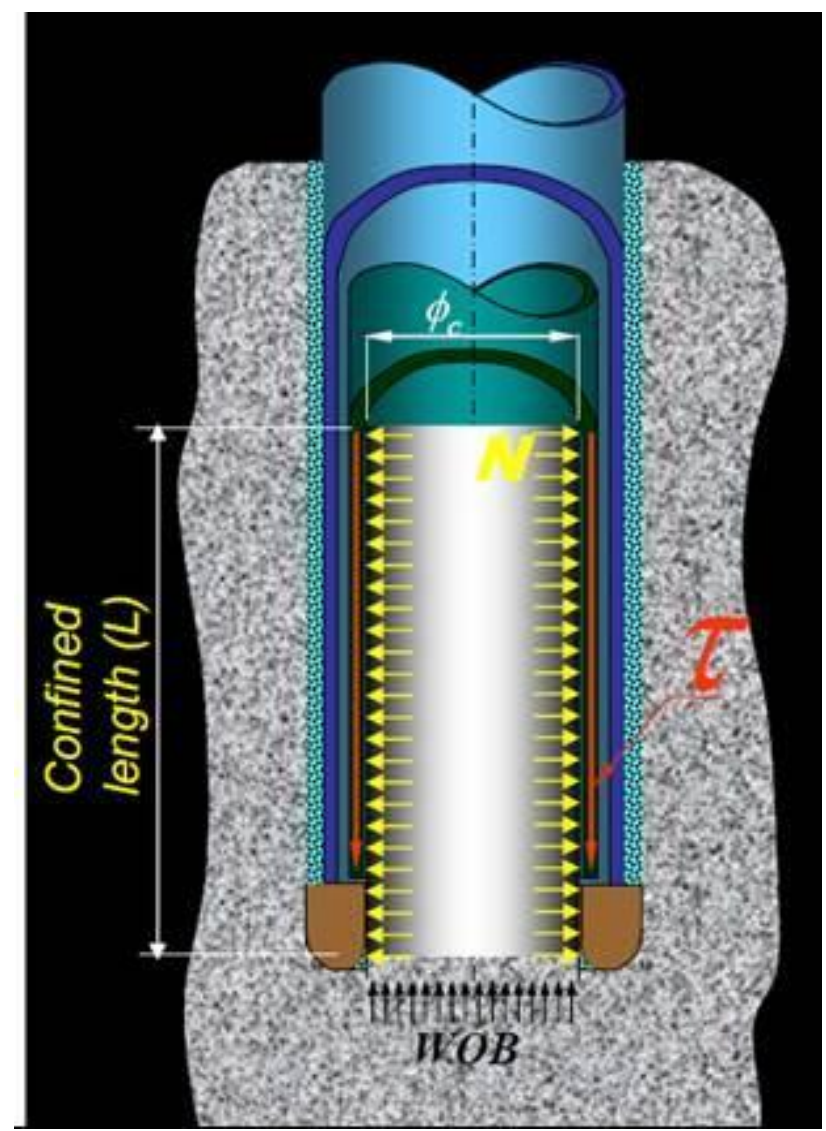

Figura 2.11: Esforços atuando sobre o cilindro de rocha durante a testemunhagem [3]

A partir dos dados de uma corrida de testemunhagem no campo de Albacora, onde foram recuperados 3,3 m e o peso sobre broca durante a operação entre 7 e $8 \mathrm{klb}$, os autores determinaram um valor estimado para o produto $\mu$. $\sigma_{\mathrm{N}}$ em 5 psi

A validação do modelo proposto foi realizada a partir de uma operação de testemunhagem realizada em um campo da Bacia de Campos composto por um arenito inconsolidado. Nesta operação a recuperação média foi de 3,3 m e a tensão axial no testemunho resultante do peso sobre broca aplicado manteve-se na faixa de 7000 a 8000 psi. A partir de tais resultados de campo foi criado o ábaco representado na Figura 2.12. 


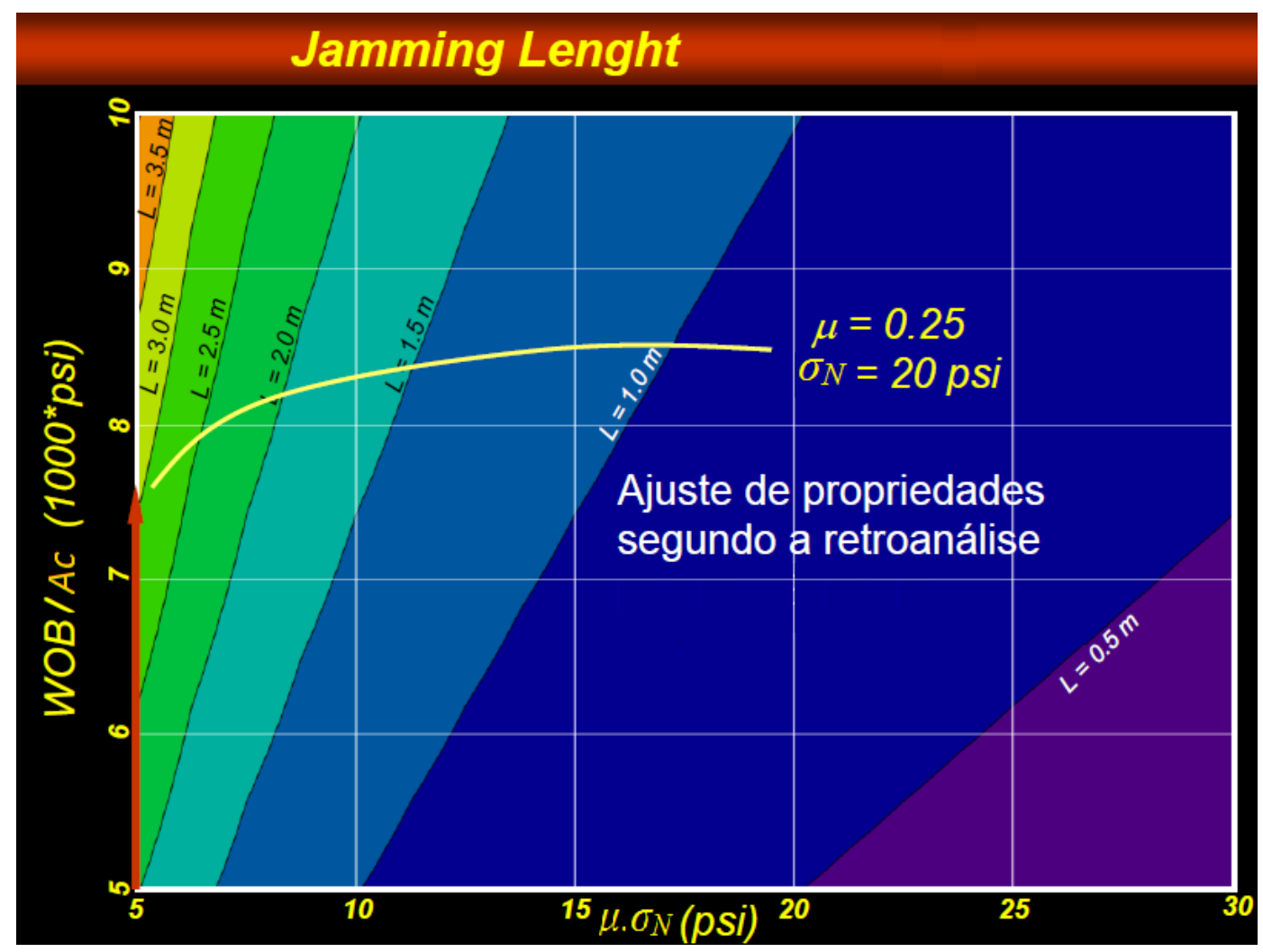

Figura 2.12: Esforços atuando sobre o cilindro de rocha durante a testemunhagem [3]

Um testemunho acunhado pode se manter íntegro em seu trecho confinado no interior do tubo de alumínio. Entretanto, há um trecho da amostra na sua extremidade inferior que permanece fora do tubo, e desta forma sujeita a uma compressão não confinada. A Figura 2.13 mostra o comportamento em ambos os casos. 


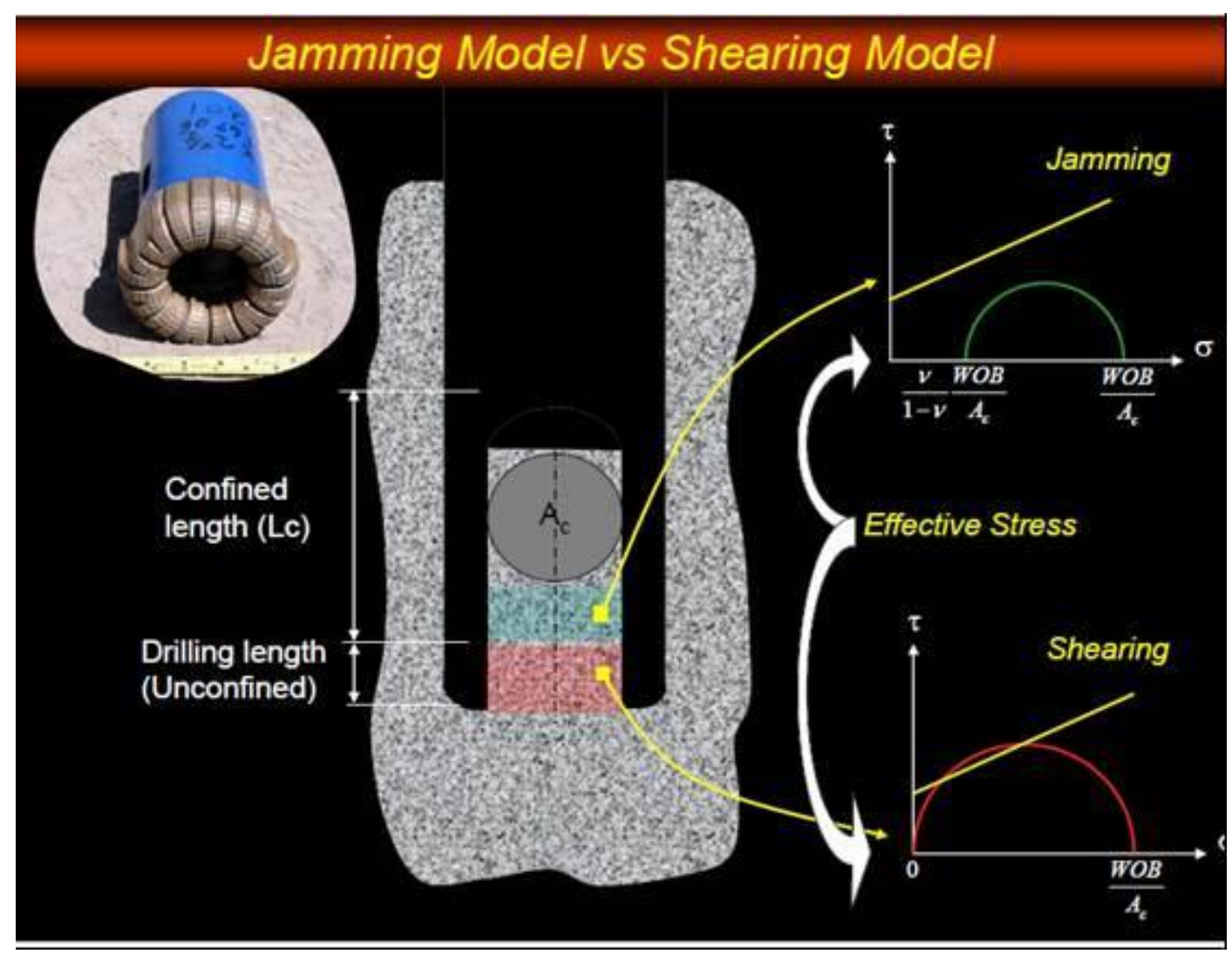

Figura 2.13: Modelos para a amostra acunhada e confinada no interior do tubo e para o trecho não confinado no qual a rocha sofre o colapso [2]

\subsection{2. \\ Modelo do cisalhamento}

Em uma condição onde uma rocha e barrilete de testemunhagem possuíssem idealmente resistência infinita, o acunhamento seria um fenômeno de fácil solução, pois ao cessar o avanço, bastaria aumentar o peso sobre broca para prosseguir a operação. No entanto, a resistência da rocha não é infinita, e os arenitos, em especial, podem apresentar baixíssima resistência ao cisalhamento.

Desta forma, em função dos parâmetros de resistência da rocha é estabelecido a seguir o modelo do cisalhamento, que de forma conjunta com o modelo do acunhamento, descrito anteriormente, permitirá uma dedução analítica do comprimento a ser testemunhado em uma rocha com determinada resistência. 
A partir da envoltória de Mohr (Figura 2.14: Modelo do cisalhamento):

$$
\tau=C+\sigma \cdot \tan (\phi)
$$

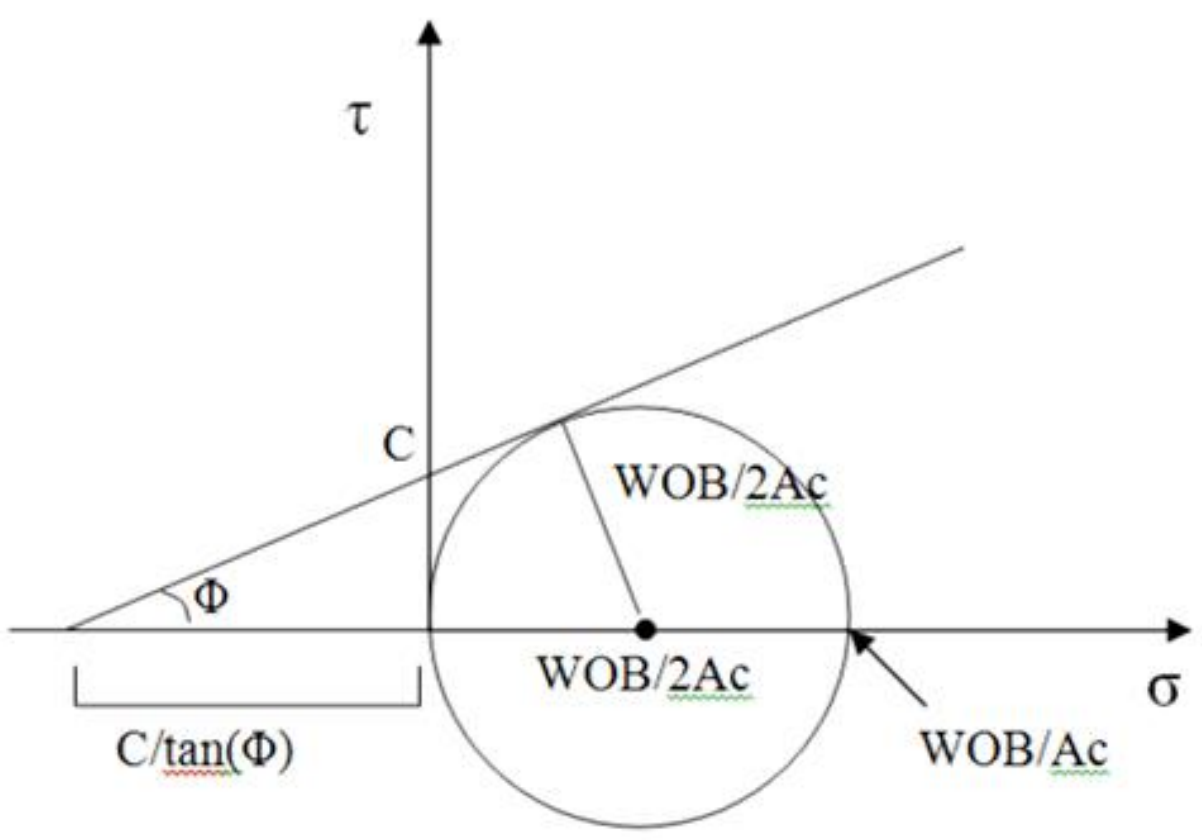

Figura 2.14: Modelo do cisalhamento

$$
\begin{aligned}
& \frac{W O B}{2 A c}=\left[\frac{C}{\tan (\phi)}+\frac{W O B}{2 A c}\right] \cdot \operatorname{sen} \phi \\
& \frac{W O B}{2 A c}-\frac{W O B}{2 A c} \cdot \operatorname{sen} \phi=\left[\frac{C}{\tan (\phi)}\right] \operatorname{sen} \phi
\end{aligned}
$$

$$
\frac{W O B}{2 A c}(1-\operatorname{sen} \phi)=C \cdot \cos \phi
$$


Desta forma, a coesão mínima da rocha (C) para que esta não colapse é dada pela equação a seguir:

$$
C=\frac{W O B}{A c} \frac{(1-\operatorname{sen} \phi)}{2 \cdot \cos \phi}
$$

A partir dos modelos do acunhamento (Eq. 2.6) e do cisalhamento (Eq. 2.8), se obtém a equação para o comprimento testemunhado até que o colapso da amostra ocorra:

$$
L=\frac{C \cdot D}{4 \mu \cdot \sigma_{N}} \cdot \frac{2 \cos \phi}{(1-\operatorname{sen} \phi)}
$$

Além da dedução analítica, os autores determinaram o produto $\mu . \mathrm{N}$ através de uma engenharia reversa, utilizando dados estatísticos acerca dos acunhamentos em testemunhagens em arenitos inconsolidados. No modelo proposto nesta tese, $\mathrm{o}$ coeficiente de atrito $(\mu)$ e a tensão normal são determinados experimentalmente, o que o confere maior exatidão.

Como exemplo de resultados, Ferreira et al (2007) previram uma recuperação de até $7,1 \mathrm{~m}$ em um arenito com coesão de 400 psi.

\subsection{3.}

\section{Acrescentando o peso próprio do testemunho ao modelo analítico inicial}

No modelo descrito no ítem anterior, os autores consideraram apenas o atrito entre a amostra e o tubo como responsável por um eventual colapso da rocha na base da amostra. No entanto, em rochas com resistência tão baixa é 
pertinente avaliar se o peso da própria coluna de rocha ofereceria uma contribuição considerável à sua ruptura.

Incluindo o peso próprio do testemunho no equilíbrio de forças obtém-se o diagrama mostrado na Figura 2.15:

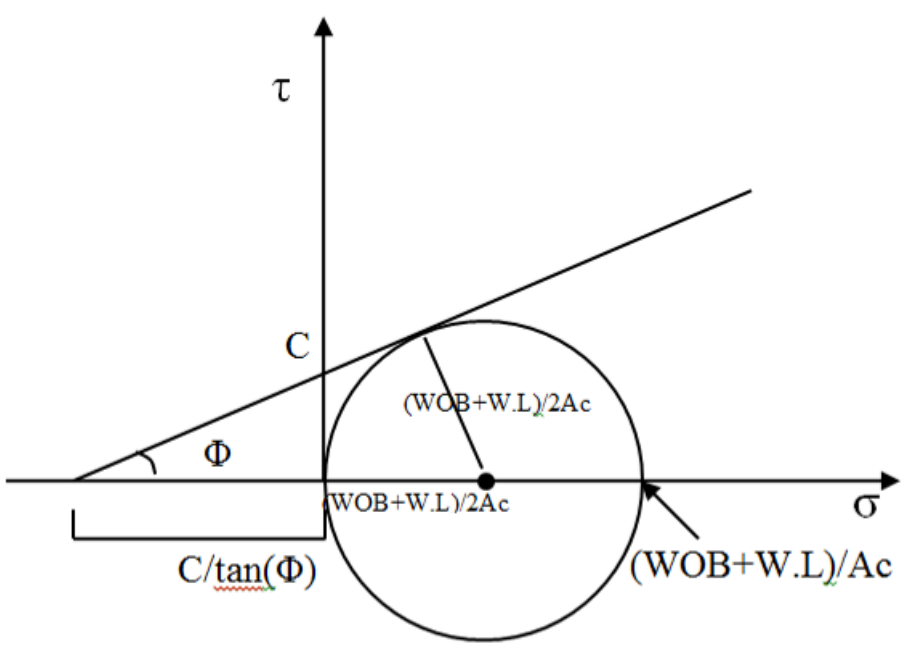

Figura 2.15: Círculo de Mohr para o trecho de rocha não confinado

$$
\frac{W O B+W * L}{2 A c}=\left[\frac{C}{\tan (\phi)}+\frac{W O B+W * L}{2 A c}\right] \cdot \operatorname{sen} \phi
$$

Onde:

W: peso linear da amostra por unidade de comprimento[lbf/in]

L: comprimento testemunhado [in] 


$$
\begin{aligned}
& \frac{W O B+W * L}{2 A c}-\frac{W O B+W * L}{2 A c} \cdot \operatorname{sen} \phi=\left[\frac{C}{\tan (\phi)}\right] \operatorname{sen} \phi \\
& \frac{W O B+W^{*} L}{2 A c}(1-\operatorname{sen} \phi)=C \cdot \cos \phi
\end{aligned}
$$

Desta forma:

$$
C=\frac{(W O B+W * L)}{A c} \frac{(1-\operatorname{sen} \phi)}{2 \cdot \cos \phi}
$$

A partir dos modelos do acunhamento e do cisalhamento, se obtém a equação para o comprimento testemunhado até que o colapso da amostra ocorra.

Lembrando o modelo do acunhamento:

$$
L=\frac{W O B}{\mu \cdot \sigma_{N} \cdot \pi \cdot D}
$$

Então:

$$
\begin{gathered}
C=\frac{\left(L \cdot \mu \cdot \sigma_{N} \cdot \pi \cdot D+W \cdot L\right)}{A_{c}} \cdot \frac{(1-\operatorname{sen} \phi)}{2 \cdot \cos \phi} \\
L=\frac{C \cdot A_{C}}{\left(\mu \cdot \sigma_{N} \cdot \pi \cdot D+W\right)} \cdot \frac{2 \cdot \cos \phi}{(1-\operatorname{sen} \phi)}
\end{gathered}
$$




$$
L=\frac{C \cdot \pi \cdot D^{2}}{2\left(\mu \cdot \sigma_{N} \cdot \pi \cdot D+W\right)} \cdot \frac{\cos \phi}{(1-\operatorname{sen} \phi)}
$$

O peso linear do testemunho $(\mathrm{W})$ pode ser expresso da seguinte maneira:

$$
W=\gamma \cdot A c=\gamma \frac{\pi D^{2}}{4}
$$

Onde $\gamma$ é o peso específico do arenito.

$$
L=\frac{C}{\left(2 \frac{\mu . \sigma_{N}}{D}+\gamma \frac{1}{2}\right)} \cdot \frac{\cos \phi}{(1-\operatorname{sen} \phi)}
$$

Um exemplo fictício com os dados abaixo apresentou um resultado de 5,19 m, muito próximo do resultado sem considerar o peso próprio do testemunho que foi de $5,28 \mathrm{~m}$.

$$
\begin{aligned}
& \rho=2323 \mathrm{~kg} / \mathrm{m}^{3}=0,084 \mathrm{lb} / \mathrm{in}^{3} \\
& \mu . \sigma_{N}=5 \mathrm{psi} \\
& \mathrm{D}=4 \text { pol } \\
& \Phi=30^{\circ} \\
& \mathrm{C}=300 \mathrm{psi}
\end{aligned}
$$

O resultado sugere que a influência do peso da coluna de rocha, nunca tão seja irrelevante frente aos esforços provocados pelo arraste, e desta forma pode ser mais facilmente desprezada. 


\section{8.}

\section{Modelo analítico proposto}

É importante ressaltar que o modelo anterior foi criado a partir de uma inferência do produto $\mu . \sigma_{N}$ obtida a partir dos resultados de campo. Tal modelo não explica o fenômeno integralmente. Ele não mostra, por exemplo, como se comporta o aumento da tensão normal e, consequentemente, do arraste na medida em que ocorre o encamisamento do testemunho pelo tubo. De forma a responder tais questões, se desenvolveu uma análise das relações entre os esforços envolvidos na interação da rocha com a parede do tubo.

Em uma primeira análise facilmente se percebe que, uma vez estabelecido o contato, o arraste da amostra de testemunho é um fenômeno que se retroalimenta, ou seja, à medida que o cilindro de rocha sofre uma compressão pela resistência ao movimento exercida pelo atrito, sofre também uma deformação lateral, aumentando a sua tensão normal sobre a parede do tubo e consequentemente aumentando ainda mais o arraste (Figura 2.16).

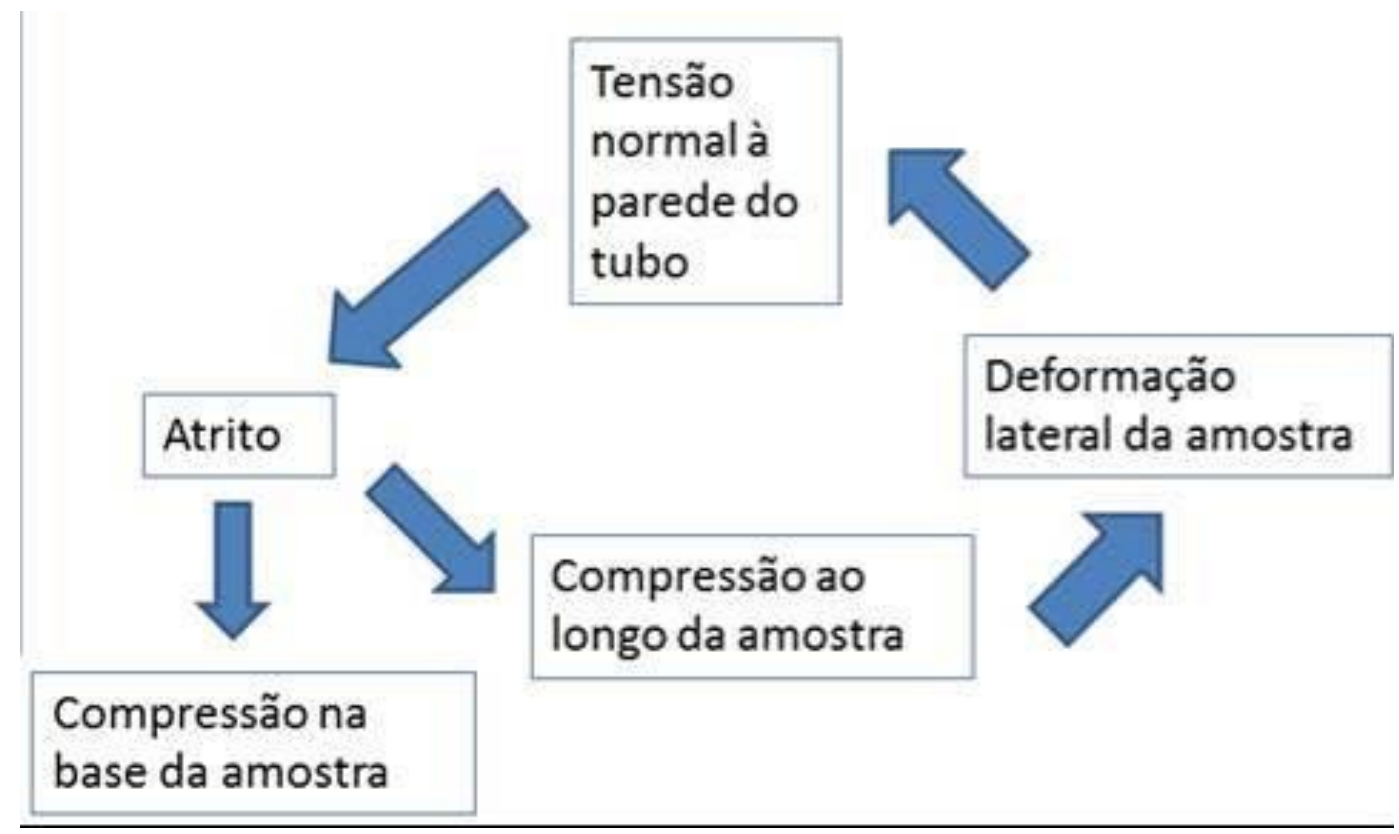

Figura 2.16: Dinamismo nos esforços entre a amostra de rocha e o tubo 
Partindo do modelo de Coulomb para o atrito, se obtém:

$F_{a t}=\mu . N$

$\sigma_{y} \cdot A_{s}=\mu . \sigma_{x} \pi \cdot D \cdot l$

$\sigma_{y} \cdot \frac{\pi \cdot D^{2}}{4}=\mu \cdot \sigma_{x} \pi \cdot D \cdot l$

$\sigma_{y} \cdot=\frac{\mu \cdot \sigma_{x} \pi \cdot 4 \cdot l}{D}$

Onde:

- Fat : Força de atrito

- $\mu$ : coeficiente de atrito

- N: Força normal exercida pela rocha sobre a parede do tubo

- $\sigma y:$ tensão axial no cilindro de rocha encamisado

- $\sigma_{Y}$ : tensão axial no cilindro de rocha não confinado

- $\sigma x$ : tensão radial no cilindro de rocha encamisado

- D:diâmetro interno do tubo

- 1: comprimento do cilindro de rocha em contato com o tubo

No caso particular da compressão confinada:

$$
\sigma_{x}=\left(\frac{v}{1-v}\right) \cdot \sigma_{y}
$$

Então:

$\sigma_{Y}=\frac{\mu \cdot \sigma_{y} \pi \cdot 4 \cdot l}{D} \cdot \frac{v}{(1-v)}$

onde $v$ é o coeficiente de Poisson da amostra.

A Equação 2.18 mostra então que no modelo do acunhamento a tensão axial é uma grandeza proporcional a si mesma, dependente do estado anterior. 
Buscando a solução do problema, discretiza-se o cilindro do testemunho em elementos na forma de discos, conforme a Figura 2.17:

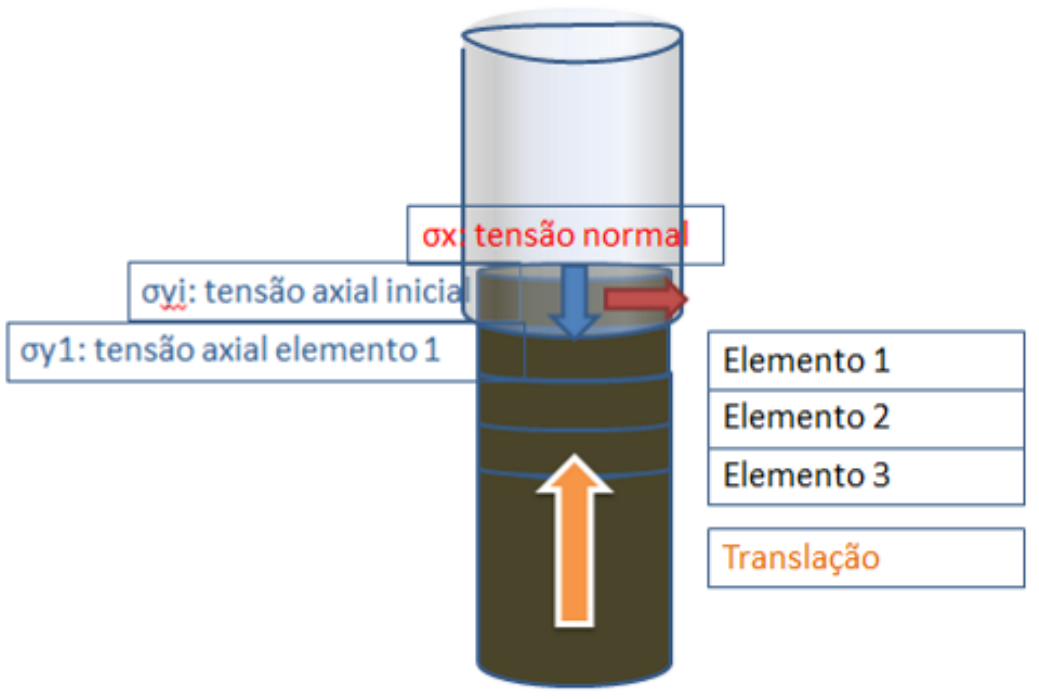

Figura 2.17: Discretização do problema estado inicial ( $\mathrm{t}=0)$

Partindo de uma situação inicial, quando a tensão axial é representada por $\sigma_{\text {yi }}$ a tensão axial no próximo a entrar no tubo:

$$
\begin{gathered}
\sigma_{Y 1}=\sigma_{y i}+\frac{\mu \cdot \sigma_{y i} \cdot \pi \cdot 4 \cdot \Delta l}{D} \cdot \frac{v}{(1-v)} \\
\sigma_{Y 1}=\sigma_{y i}\left(1+\frac{\mu \cdot \pi \cdot 4 \cdot \Delta l}{D} \cdot \frac{v}{(1-v)}\right)
\end{gathered}
$$




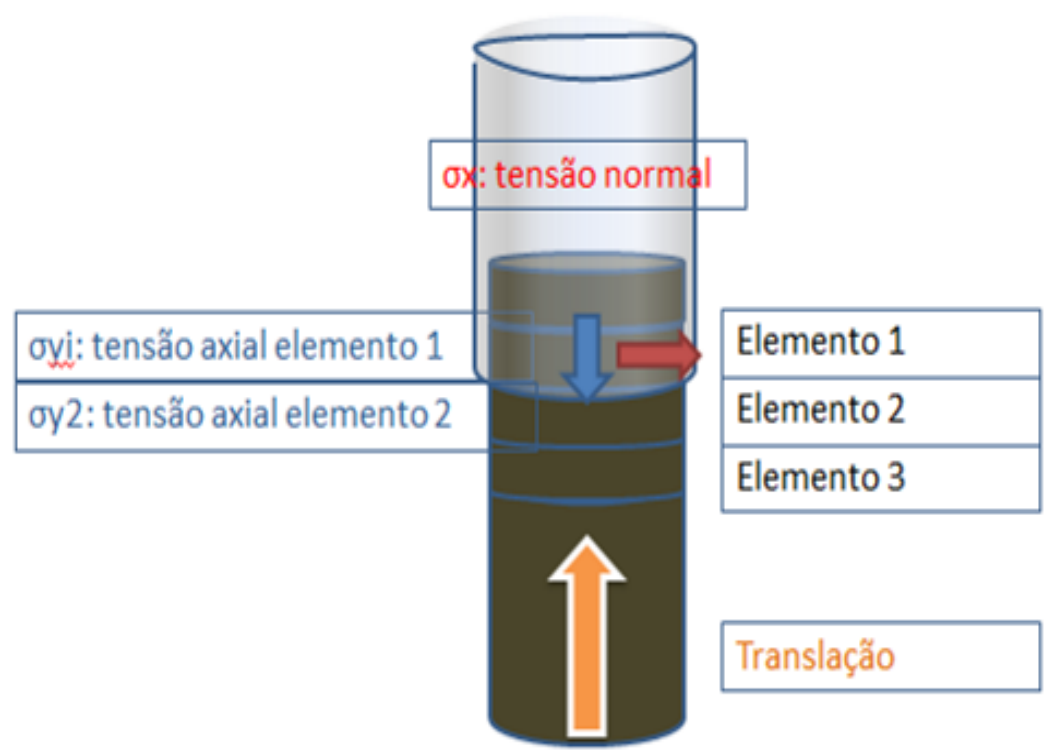

Figura 2.18: Discretização do problema estado seguinte $(\mathrm{t}=1)$

Analogamente, no instante $\mathrm{t}=1$ quando o elemento 2 está prestes a entrar no tubo:

$$
\begin{aligned}
& \sigma_{Y 2}=\sigma_{y 1}+\frac{\mu \cdot \sigma_{y 1} \cdot \pi \cdot 4 \cdot \Delta l}{D} \cdot \frac{v}{(1-v)} \\
& \sigma_{Y 2}=\sigma_{y i}\left(1+\frac{\mu \cdot \pi \cdot 4 \cdot \Delta l}{D} \cdot \frac{v}{(1-v)}\right)^{2}
\end{aligned}
$$

Isso significa que para $\mathrm{o}$ instante $\mathrm{t}=\mathrm{n}$ quando $\mathrm{o}$ elemento $\mathrm{n}$ estiver prestes a entrar no tubo:

$$
\sigma_{y n}=\sigma_{y i}\left(1+\frac{\mu \cdot \pi \cdot 4 \cdot \Delta l}{D} \cdot \frac{v}{(1-v)}\right)^{n}
$$

Sendo que $\Delta \mathrm{l}$ é o comprimento de cada elemento e se equivale ao total encamisado (1), dividido pelo número de elementos (n), resultando: 


$$
\sigma_{y n}=\sigma_{y i}\left(1+\frac{\mu \cdot \pi \cdot 4 \cdot l}{D \cdot n} \cdot \frac{v}{(1-v)}\right)^{n}
$$

Refinando a resolução do modelo, com n tendendo ao infinito, uma vez que:

$$
\lim _{x \rightarrow \infty} A \cdot\left(1+\frac{B y}{x}\right)^{x}=A \cdot e^{B y}
$$

Então:

$$
\lim _{n \rightarrow \infty} \sigma_{y n}=\sigma_{y i} \cdot e^{\frac{4 \cdot \mu}{D} \cdot\left(\frac{v}{1-v}\right) \cdot l}
$$

O resultado acima prova o que a suspeita empírica dos profissionais de testemunhagem, de que, uma vez iniciado o contato, o arraste aumenta de forma exponencial, culminando no acunhamento.

É muito importante enfatizar ao leitor que este modelo, diferente do capítulo anterior, representa os esforços sobre a amostra de rocha depois de estabelecido o contato com a parede do tubo. Sem entrar na questão de quando esse contato se inicia. O modelo anterior, por utilizar como entrada os dados de campo, automaticamente incorporava o período anterior ao contato e por isso deve levar a resultados menos conservadores.

\section{9.}

\section{Influência do fluido de perfuração no atrito}

É natural que os diferentes fluidos de perfuração e sua natureza acerca da lubricidade tenham plena influência no atrito. Existem inúmeras pesquisas que avaliam, por exemplo, a influência do fluido no arraste (atrito) entre a coluna de perfuração no poço. Os modelos que subsidiam os projetos dos poços são 
alimentados com valores padrão para os coeficientes de atrito entre a coluna de perfuração e o revestimento e/ou entre a coluna e a rocha. Valores esses tabelados em função da composição do fluido, baseado em água ou sintético, a base de parafina. No caso do fluido de base aquosa, aditivos podem ser incorporados de modo a incrementar sua lubricidade, e assim reduzir o arraste da coluna de perfuração, algo importante principalmente em poços direcionais.

Se o fluido de perfuração tem influência considerável na interação entre a coluna e a parede do poço, ainda mais importante é sua influência no íntimo contato entre a amostra de testemunho e o interior do barrilete de testemunhagem. Sendo assim, o experimento para determinar o coeficiente de atrito entre a areia e o tubo deveria, idealmente, incorporar o fluido de perfuração. Assim incorporando o efeito da composição do fluido sobre o coeficiente de atrito rocha-tubo interno. Entretanto, o capítulo 3 mostrará que a realização do primeiro experimento proposto apenas com areia seca já implicou uma série de dificuldades. Reproduzilo com a adição do fluido se tornaria uma tarefa praticamente inviável. Mesmo porque, para o experimento em questão, foi necessária a desmontagem de parte da prensa utilizada para que se aproveitasse todo o seu curso, e assim fosse capaz de comprimir o êmbolo sobre a coluna de areia e o êmbolo inferior. Incorporar a esse conjunto algum recipiente capaz de reter o fluido de perfuração seria dimensionalmente difícil, e a organização complexa tornaria extremamente demorada a montagem e desmontagem do aparato.

Essa foi uma das motivações da realização de um segundo experimento utilizando um segmento de tubo como "plano" inclinado. Esse experimento, por ser mais simples e não requerer instrumentação especial pode ser executado em um galpão de oficina, permitindo a incorporação dos fluidos de perfuração. A execução e os resultados são mostrados posteriormente nos capítulos 3 e 5 . 


\subsection{0. \\ Relações entre as grandezas na compactação de uma coluna de areia no interior do tubo de alumínio}

\subsection{1.}

\section{Esforços na parede do tubo}

De modo a permitir uma correta interpretação dos resultados é fundamental conhecer como se relacionam as grandezas que inferindo-se deseja medir ou inferir. Voltando à fase de adensamento da areia, a prensa e a célula de carga fornecem o valor do deslocamento e da força de compactação aplicada. Já as rosetas extensométricas medem as deformações circunferencial e axial (longitudinal) da parede externa do tubo de alumínio em diferentes pontos.

Seguindo a convenção acadêmica, utiliza-se neste trabalho a notação $\sigma_{1}$ e $\sigma_{3}$ para as tensões axial e lateral sobre o cilindro de areia, respectivamente, assim como $\varepsilon_{1}$ e $\varepsilon_{3}$ para as deformações nas respectivas direções.

A partir da deformação circunferencial, infere-se a tensão normal exercida pela coluna de areia sobre a superfície interna do tubo de alumínio utilizando o modelo para um cilindro de paredes finas:

$$
\sigma_{c}=\frac{u . d}{2 . t}
$$

Onde:

$\sigma_{c}:$ tensão circunferencial;

u: pressão interna no cilindro, equivalente à tensão lateral na coluna de areia, $\sigma_{3}$

d: diâmetro interno do cilindro $=13,67 \mathrm{~cm}$;

$\mathrm{t}$ : espessura de parede do cilindro $=0,38 \mathrm{~cm}$.

$\mathrm{Na}$ parede do cilindro sujeito a pressão interna, as tensões circunferencial e longitudinal são as tensões principais. Para se obtê-las a partir dos valores de deformação é necessário utilizar as equações abaixo, correspondentes a um cilindro de paredes finas: 


$$
\begin{gathered}
\sigma_{c}=\frac{E\left(\varepsilon_{c}+v \cdot \varepsilon_{l}\right)}{\left(1-v^{2}\right)} \\
\sigma_{l}=\frac{E\left(\varepsilon_{l}+v \cdot \varepsilon_{c}\right)}{\left(1-v^{2}\right)}
\end{gathered}
$$

\section{Onde:}

$\sigma_{c}$ : tensão circunferencial;

$\sigma_{1}:$ tensão longitudinal (axial);

$\varepsilon_{c}$ : deformação circunferencial;

$\varepsilon_{\mathrm{c}}$ : deformação longitudinal (axial);

E: módulo de Young do material = $70 \mathrm{GPa}$;

v: coeficiente de Poisson do material $=0,33$.

Sendo assim, a tensão de confinamento da areia pode ser determinada utilizando-se a equação para determinar a tensão circunferencial na parede do tubo a partir dos dados de deformação circunferencial e longitudinal fornecidos pelos strain gauges, combinada com o modelo para a tensão circunferencial no cilindro de paredes finas:

$$
\sigma_{3}=\frac{2 \cdot t \cdot E\left(\varepsilon_{c}+v \cdot \varepsilon_{l}\right)}{d\left(1-v^{2}\right)}
$$

Tal relação é válida apenas para a fase de compactação da areia, quando o único esforço sobre o tubo é, em teoria, aquele exercido pela compactação da areia contida em seu interior.

Durante a fase de compactação, obtém-se ainda a deformação axial da coluna de areia $\left(\varepsilon_{1}\right)$ a partir do curso da prensa e a tensão axial $\left(\sigma_{1}\right)$ dividindo a força medida pela célula de carga pela área da seção transversal da coluna de areia. 


\subsection{2.}

\section{Comportamento mecânico de areias}

Em um carregamento primário a taxa de deformação de um material como os solos não consolidados apresenta uma componente elástica e outra plástica, provocada pela compactação, usualmente havendo ainda uma terceira, dependente do tempo (creep):

$$
\mathrm{d} \varepsilon=\mathrm{d} \varepsilon^{\text {elast }}+\mathrm{d} \varepsilon^{\text {plast }}+\mathrm{d} \varepsilon^{\mathrm{cr}}
$$

Diferente de outros materiais, neste comportamento "elasto-plástico" a plasticidade está presente desde o início do carregamento e não apenas após o ponto de ruptura. A componente plástica é causada principalmente pelo deslocamento e rearranjo entre partículas. Já a componente elástica pelo armazenamento de energia nas partículas, individualmente [6].

$\mathrm{Na}$ trajetória de descarregamento (ou em um segundo carregamento em um trecho já consolidado) prevalece o alívio da energia das partículas, embora haja ainda algum deslizamento reverso entre as partículas [6]. Tal deslizamento pode ser gradativamente eliminado com sucessivos ciclos de carregamento/descarregamento, até que o ciclo não apresente nenhuma deformação permanente adicional.

$\mathrm{Na}$ dificuldade de se executar inúmeros ciclos, o descarregamento é a melhor fase para se determinar os parâmetros elásticos da areia.

O elevado módulo de elasticidade da liga de alumínio que compõe o tubo faz com que a deformação circunferencial deste, e consequentemente a deformação lateral da coluna de areia seja substancialmente menor que a deformação axial da própria areia. Isso permite que se aproxime a fase de compactação a um ensaio edométrico, onde a deformação lateral da amostra ( $\left.\varepsilon_{3}\right)$ é restringida. 
A partir da lei de Hooke, para um meio isotrópico, tem-se que:

$$
\begin{aligned}
& \varepsilon_{1}=\frac{1}{E}\left[\sigma_{1}-v\left(\sigma_{2}+\sigma_{3}\right)\right] \\
& \varepsilon_{2}=\frac{1}{E}\left[\sigma_{2}-v\left(\sigma_{1}+\sigma_{3}\right)\right] \\
& \varepsilon_{3}=\frac{1}{E}\left[\sigma_{3}-v\left(\sigma_{2}+\sigma_{1}\right)\right]
\end{aligned}
$$

Para o caso particular do ensaio edométrico: $\varepsilon_{2}=\varepsilon_{3}=0$.

Então:

$$
\sigma_{2}=v\left(\sigma_{1}+\sigma_{3}\right)
$$

$$
\sigma_{3}=v\left(\sigma_{1}+\sigma_{2}\right)
$$

Substituindo Eq. 2.25 em Eq. 2.24:

$$
\sigma_{2}=\sigma_{3}=\left(\frac{v}{1-v}\right) \sigma_{1}
$$

Para o ensaio edométrico, as seguintes relações são válidas [7], contanto que o material seja elástico:

$$
\begin{aligned}
& E_{\text {oed }}=\frac{E(1-v)}{(1+v) \cdot(1-2 \cdot v)} \\
& K_{0}=\frac{\Delta \sigma_{h}}{\Delta \sigma_{v}}=\frac{v}{1-v}
\end{aligned}
$$




\subsection{1 . Modelagem no método dos elementos finitos (MEF)}

No presente trabalho, o MEF foi utilizado em duas situações. A primeira foi a reprodução da fase do experimento de compactação da areia. $\mathrm{O}$ intuito nesse caso foi o de comparar os dados experimentais medidos pelos strain gauges com as simulações geradas no computador adotando diversos coeficientes de atrito e então, por comparação, encontrar aquele coeficiente que mais aproxima os resultados da simulação dos resultados reais. O coeficiente de atrito encontrado foi utilizado então para corroborar o valor determinado no experimento de plano inclinado com a superfície seca.

A segunda situação consistiu em reproduzir a interação entre o testemunho e o barrilete de testemunhagem, permitindo não apenas estabelecer um modelo para a previsão do acunhamento, mas também respondendo questões que pairam na testemunhagem. Como por exemplo, a real influência de variáveis como o diâmetro do testemunho.

\subsection{1.}

\section{Ferramenta utilizada - o programa Abaqus}

O Abaqus é um software comercial que utiliza o Método dos Elementos Finitos para análise em mecânica estrutural, mecânica dos fluidos, termodinâmica e até mesmo eletromagnetismo, permitindo ainda a modelagem de uma vasta gama de materiais. Tais qualidades o tornam uma ferramenta popular no meio acadêmico e em instituições de pesquisa [8].

Através dos softwares que compõem o Abaqus, o usuário é capaz de executar os três estágios que compõem a análise:

1. Modelagem ou pré-processamento: descrição lógica do problema, incluindo a geometria, os materiais e suas propriedades, esforços, condições de contorno, malhas, etc. Esta etapa pode ser realizada utilizando softwares de CAD compatíveis;

2. Avaliação e Processamento: avaliação da consistência do modelo criado e execução das iterações utilizando o MEF. Pode aplicar a 
integração implícita (Abaqus/Standard) ou explícita (Abaqus/Explicit);

3. Pós-processamento: apresentação dos resultados através de relatórios, gráficos, animações, etc.

Quanto à forma de solução, o Abaqus pode ser subdividido em duas ferramentas: ABAQUS/Standard e ABAQUS/Explicit.

O ABAQUS/Standard utiliza a integração implícita, é mais estável, mas requer um razoável desempenho computacional para uma resolução de cálculos. Não é recomendável para modelos altamente não-lineares, com muitas interações entre superfícies ou com carregamentos com uma forte componente transiente, pois em tais situações, cada iteração requer a solução de um sistema de equações lineares de grande porte.

Já o ABAQUS/Explicit trabalha muito melhor com não-linearidades, contatos complexos entre superfícies e carregamentos transientes, mas utiliza pequenos incrementos de tempo e pode ser instável em alguns casos. A formulação explícita foi desenvolvida originalmente para problemas de impactos em alta velocidade, onde a consideração dos efeitos dinâmicos como a inércia e ondas e choque representam um papel essencial na busca da solução.

A formulação explícita foi adotada em algumas simulações desse trabalho não para a incorporação dos efeitos dinâmicos, mas para buscar uma maior precisão em modelos extremamente sensíveis às interações entre superfícies. A adoção da formulação explícita, mesmo em modelos quasi-static, requer alguns cuidados quanto ao desempenho. Em muitos casos a modelagem do processo em seu período de tempo original é inviável, pois requer passos de tempo mínimos, e consequentemente milhões de iterações [9]. Isso acontece porque a formulação explícita exige que as ondas de choque não atravessem o menor dos elementos em um único passo. Para contornar esse problema existem duas possibilidades a depender da natureza do material em que o carregamento é aplicado:

- Reduzir artificialmente a escala de tempo através do incremento da taxa de carregamento. Solução adotada quando o material em questão não é sensível à taxa de carregamento; 
- Utilizar o recurso mass scaling para aumentar artificialmente a densidade do material. Solução adotada quando, por exemplo, o material em questão é sensível à taxa de carregamento como, por exemplo, amortecedores.

Mass Scaling é um recurso que automaticamente aumenta a densidade apenas dos elementos que estão limitando o desempenho e impedindo o tempo máximo do passo determinado pelo usuário. Esse recurso é perfeitamente aplicável em modelos quase-estáticos onde a energia cinética é baixa em comparação à energia interna.

\subsection{2. \\ Modelando a plasticidade no Abaqus utilizando o modelo de Drucker-Prager com fechamento de envoltória (cap)}

Para simular apropriadamente a compactação da areia era necessário incorporar, da forma mais próxima possível do real, as propriedades elastoplásticas do material. Dentre os modelos para a plasticidade oferecidos pelo Abaqus optou-se pelo Drucker-Prager com cap.

No modelo de Drucker-Prager com cap a envoltória possui dois segmentos principais: a envoltória de cisalhamento e o cap de compressão (Figura 2.19)

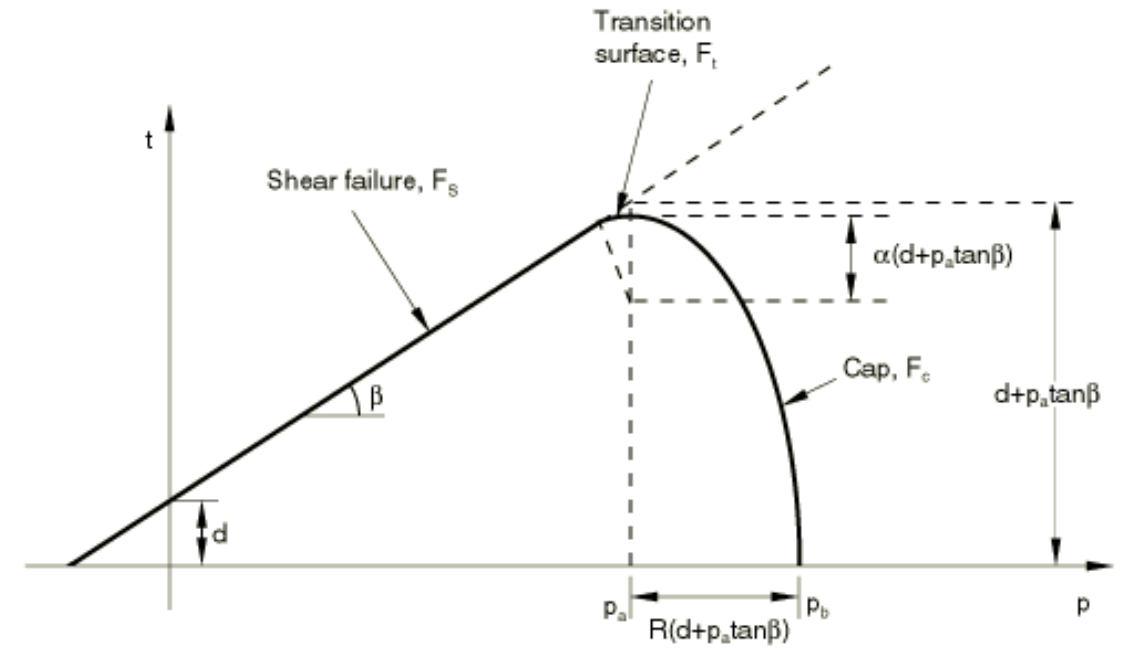

Figura 2.19: Modelo de Drucker-Prager com cap [10] 
A envoltória de plastificação do modelo de Drucker-Prager pode ser expressa por:

$$
\mathrm{Fs}=\mathrm{t}-\mathrm{p} \tan \beta-\mathrm{d}=0
$$

Onde d representa a coesão do material e $\beta$ a inclinação da trajetória no diagrama de Cambridge.

A tensão desviadora té definida por [10]:

$$
t=\frac{1}{2} q\left[1+\frac{1}{K}-\left(1-\frac{1}{K}\right)\left(\frac{r}{q}\right)^{3}\right]
$$

K é um parâmetro do material que controla o quanto a envoltória depende da tensão intermediária. No Abaqus Explicit K é 1 por default, e nesse caso t $=\mathrm{q}$.

A componente hidrostática da tensão (p) é dada por:

$$
p=-\frac{\left(\sigma_{1}+\sigma_{2}+\sigma_{3}\right)}{3}
$$

Já a componente desviadora (q):

$$
q=\sqrt{\frac{\left(\sigma_{1}-\sigma_{2}\right)^{2}+\left(\sigma_{2}-\sigma_{3}\right)^{2}+\left(\sigma_{3}-\sigma_{1}\right)^{2}}{2}}
$$

Para o caso em que $\sigma_{2}=\sigma_{3}$ :

$$
q=\sigma_{1}-\sigma_{3}
$$




\subsection{3.}

\section{Interação entre superfícies}

Para diversas aplicações no ramo da engenharia, a interação entre superfícies que sofrem um deslocamento relativo consiste em um capítulo importante na elaboração do modelo e requer uma atenção especial. No caso específico deste trabalho o coeficiente de atrito entre tais superfícies é justamente o que se deseja obter, tornando esta uma etapa ainda mais importante.

Os parágrafos a seguir descrevem as opções adotadas no modelo de reprodução do experimento, em função das opções oferecidas pelo Abaqus, em alguns casos dando ênfase àquelas oferecidas no Abaqus Explicit. Foi escolhida esta ferramenta, dentre outras razões, por oferecer maior estabilidade em modelos com interações mais complexas entre as superfícies.

Um dos pontos de definição é a escolha da superfície mestre e superfície escrava. No modelo em questão, a superfície do interior do tubo foi escolhida como superfície mestre por compor material de maior rigidez e também por possuir a malha menos refinada.

No Abaqus Standard as superfícies de contato podem ser modeladas com duas opções de discretização: nó/superfície (node-surface) e superfície/superfície (surface-surface).

$\mathrm{Na}$ primeira, a interação ocorre entre os nós da superfície escrava e a superfície mestre. O problema nesse caso é que os nós da superfície escrava podem mais facilmente ultrapassar os limites, indo além da superfície mestre, requerendo dessa forma um bom refinamento de ambas as superfícies. Requer também a definição de uma tolerância à essa invasão. Uma tolerância maior leva a resultados imprecisos. Já uma menor tolerância requer um maior desempenho computacional, pois um maior número de correções devem ser realizadas.

Já na interação superfície/superfície, ambas têm sua continuidade considerada, e uma invasão de uma sobre a outra é nesse caso menos frequente. No entanto, alguma invasão pode ocorrer no início mas gradativamente corrigida ao longo das iterações.

O Abaqus Explicit oferece duas opções de algoritmo para reprodução do modelo do contato: 1. Contato Geral (General Contact) ou 2. Par de contatos (Contact Pair). A primeira é mais simples e com menos restrições aos tipos de 
superfície envolvidos. Já a segunda apresenta maior restrição aos tipos de superfície, requerendo uma definição mais cuidadosa do contato, mas em compensação, permite algumas interações que não estão disponíveis na opção Contato Geral [Abaqus], como por exemplo:

- Contato entre corpos rígidos e deformáveis;

- Contato de um corpo com ele mesmo;

- Opção de escolha entre deslizamento finito (Finite-sliding) ou pequeno deslizamento (Small-sliding);

- Contato com corpos passíveis de erosão (devido à ruptura);

- Opções de modelos constitutivos para o comportamento do contato, relacionando pressão e tração de cisalhamento à distância de penetração movimento tangencial relativo.

- Transferência de calor.

Outro aspecto a ser observado são as duas opções de que o Abaqus dispõe para processar o deslizamento: 1.pequeno deslizamento (small sliding) e 2 . deslizamento finito (finite sliding). Na primeira, já no início da simulação é estabelecido com quais respectivos nós da superfície escrava cada segmento da superfície mestre irá interagir ao longo de todas as iterações. Naturalmente esta opção não é adequada para grandes deslocamentos entre as superfícies, quando esta relação não deve perdurar. Em tais situações a opção a ser utilizada é a do deslizamento finito, quando a relação entre os segmentos das superfícies mestre e escrava são re-estabelecidos constantemente ao longo da simulação, o que naturalmente leva a um trabalho de processamento maior.

$\mathrm{Na}$ modelagem do experimento foi adotado o deslizamento finito por se acreditar que a deformação da coluna de areia é substancial em relação à malha adotada.

\subsubsection{1.}

Propriedades da interação entre as superfícies

Definem-se as propriedades da interação entre duas superfícies através de duas componentes: uma normal e uma tangencial. 
A primeira consiste em como a simulação trata a mudança quando o contato entre as superfícies é estabelecido. A alternativa mais simples é chamada de "hard-contact", na qual as superfícies mudam subitamente de um estado para o outro à medida que o afastamento se torna zero. A restrição do contato é aplicada quando o afastamento entre as superfícies (clearance) se torna zero. No sentido oposto, a restrição do contato é eliminada quando a pressão exercida entre as superfície se torna zero, e partir deste ponto assume-se que as superfícies estão separadas. A Figura 2.20 mostra que nessa abordagem só duas situações possíveis: pressão de contato plena com afastamento zero e afastamento pleno com contato zero.

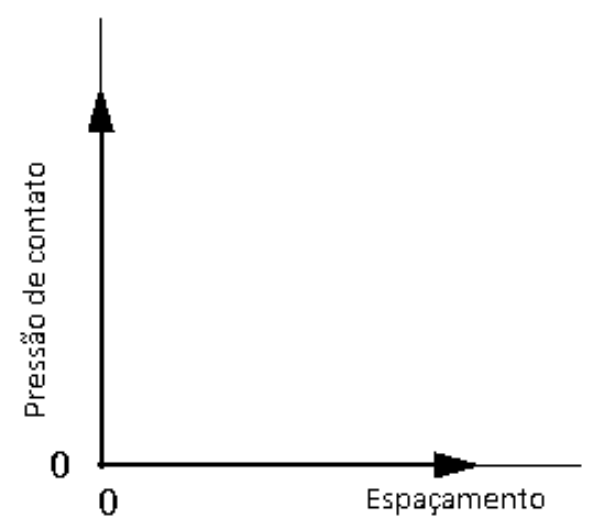

Figura 2.20: interação entre superfícies na condição Hard-contact [10]

Uma abordagem tão simplista pode ser insuficiente em problemas complexos em que o contato entre as superfícies não é permanente. Para essas situações o Abaqus provê alternativas que assumem uma condição intermediária, uma zona de desenvolvimento gradual do contato.

Como no estudo em questão as superfícies, da areia e do tubo permanecem em contato todo o tempo, tal aspecto é irrelevante. Desta forma optou-se sempre pelo "hard-contact" como padrão para a componente normal em todas as simulações realizadas.

Já a componente tangencial refere-se ao deslizamento relativo entre as superfícies e as condições em que tal deslizamento ocorre. De modo a fugir da complexidade dos cálculos exigidos por tal aspecto, e minimizar a exigência em 
processamento, o Abaqus procura distinguir situações em que o deslocamento entre as superfícies pode ser considerado desprezível.

\subsection{4.}

\section{Modelos para 0 atrito}

O Abaqus estabelece como padrão a inexistência de atrito entre as superfícies. Entretanto, em alguns problemas, como no caso deste trabalho, é relevante considerar a transmissão de forças cisalhantes entre duas superfícies, e não apenas as forças normais. O Abaqus oferece diversas opções, umas mais simples e outras mais refinadas para os modelos que descrevem o comportamento do atrito entre duas superfícies.

Um dos modelos oferecidos é o modelo de Coulomb, explicado anteriormente no item 2.6.1.

É fácil concluir que, em um caso real, a transição entre os estados estático e dinâmico não se comporte de forma tão instantânea. Desta forma o Abaqus permite ao usuário estabelecer um modelo de decaimento exponencial para o coeficiente de atrito gradar do valor estático para o dinâmico (Figura 2.21).

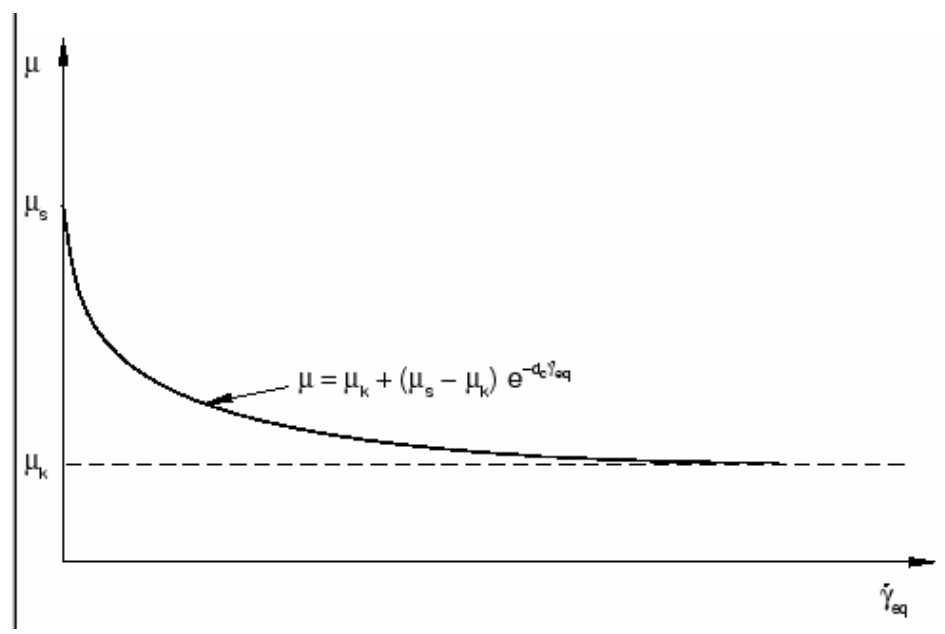

Figura 2.21: Modelo de decaimento exponencial para o coeficiente de atrito em função da taxa de deslizamento (slip rate) [10] 
Retornando ao atrito estático, o Abaqus aplica uma correção (penalty friction) que se refere à permissão de um "deslizamento elástico" entre as superfícies, representada pela linha pontilhada na Figura 2.22. Na prática isso significa que mesmo no momento em que estão aderidas assume-se algum deslocamento entre as superfícies. A rigidez dessa correção (inclinação da linha pontilhada) é definida automaticamente pelo Abaqus.

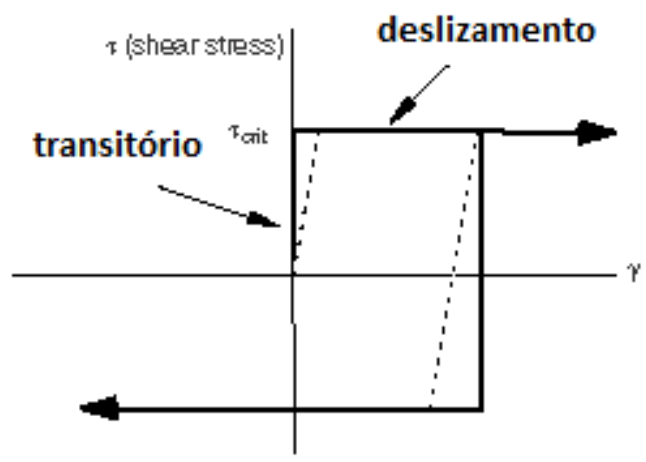

Figura 2.22: Penalty friction, modelo de penalidade do Abaqus [10]

No presente trabalho, como o deslocamento entre as superfícies ocorrem em uma taxa muito baixa limitaram-se os modelos ao atrito estático. Adicionalmente, não se encontraram justificativas para a utilização de outro modelo que não fosse o modelo de Coulomb.

\subsection{5.}

\section{Aplicação do carregamento}

A Figura 2.23, extraída das simulações do experimento de compactação da areia no interior do tubo, mostra o problema de se utilizar o ABAQUS/Explicit sem o cuidado de evitar o carregamento (ou descarregamento) instantâneo. Notase que a distribuição de deformações ao longo do tubo incorpora um fenômeno oscilatório provocado pela propagação de ondas de choque. Tal fenômeno depende ainda do tempo simulado e é inadequado quando se deseja um modelo quase-estático. 


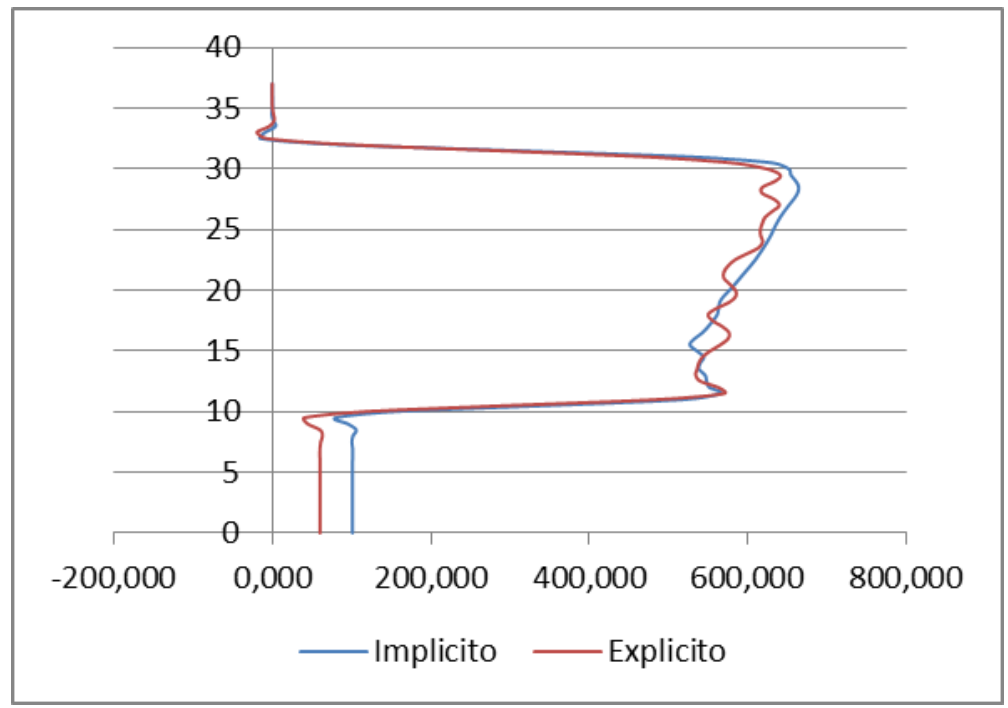

Figura 2.23: Cota do cilindro $(\mathrm{cm}) \mathrm{x}$ deformação circunferencial $(\mu \mathrm{m} / \mathrm{m})$; efeitos inerciais podem afetar os resultados

Com este tipo de problema pode-se questionar o porquê da adoção do Abaqus Explicit em substituição ao Standard (formulação implícita) em problemas estáticos ou quase-estáticos. No entanto, conforme já explicado anteriormente, o Abaqus Explicit é mais eficiente para modelos estáticos altamente não-lineares, principalmente em se tratando de problemas tridimensionais com contatos e grandes deformações.

De modo a evitar esse comportamento, foi utilizado um suavizador de amplitude (smooth step) de modo a minimizar a influência dinâmica do carregamento.

Esse suavizador gera uma transição polinomial de quinta ordem entre os valores inicial e final. A primeira e segunda derivadas das curvas no início e no fim da transição são suaves e com inclinação zero. 


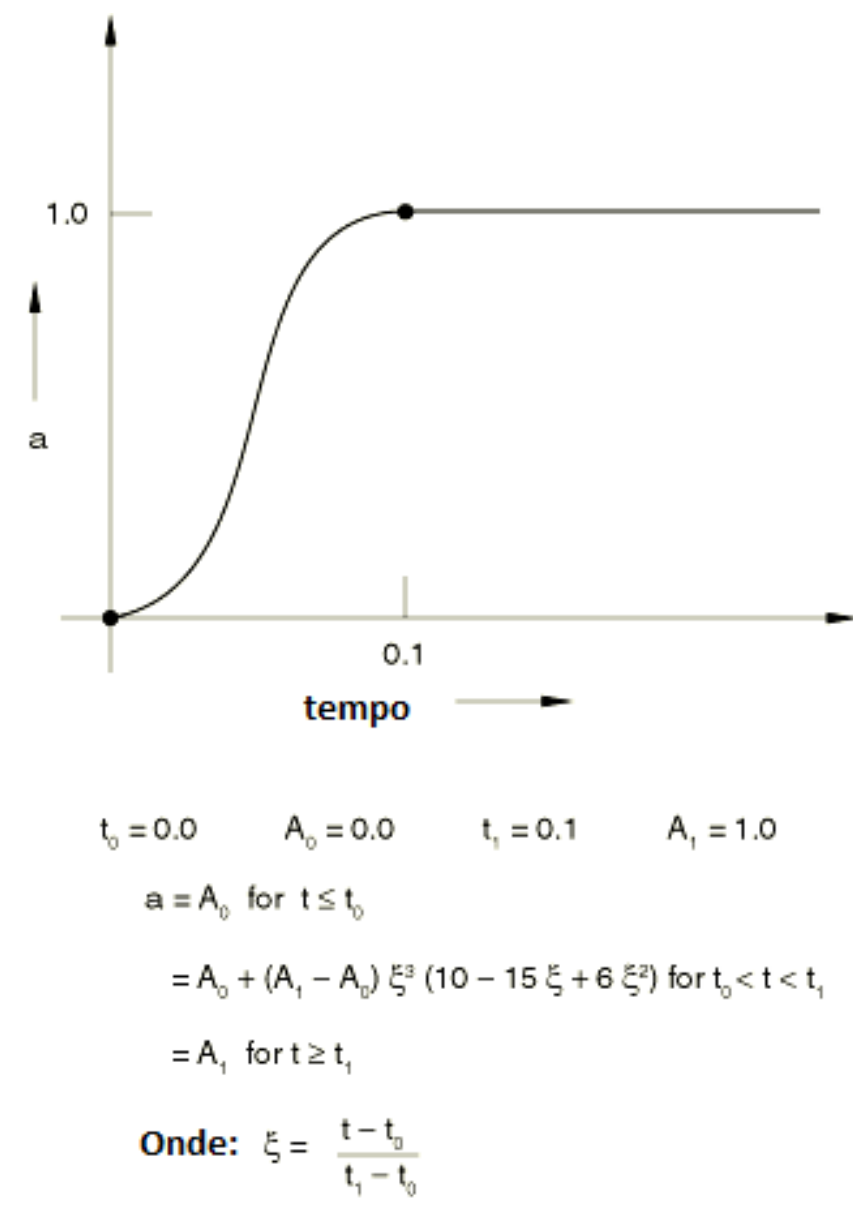

Figura 2.24: Suavização aplicada ao carregamento, Smooth step amplitude [10]

\subsection{6. \\ Malha e elementos}

No Método de elementos finitos, uma escolha inapropriada nas características e densidade da malha e elementos adotados pode aumentar a imprecisão de resultados e/ou o tempo de processamento. A busca pelas melhores opções deve refletir a topologia e demais características do meio em que a malha será aplicada. O Abaqus em geral oferece diversa gama de opções ao usuário quanto ao formato do elemento, técnicas e algoritmo de geração da malha etc., Como exemplo dessa flexibilidade, o Abaqus permite ao usuário facilmente customizar as regiões em que deseja uma malha mais refinada simplesmente marcando a posição dos nós nas extremidades do modelo (Figura 2.25). 

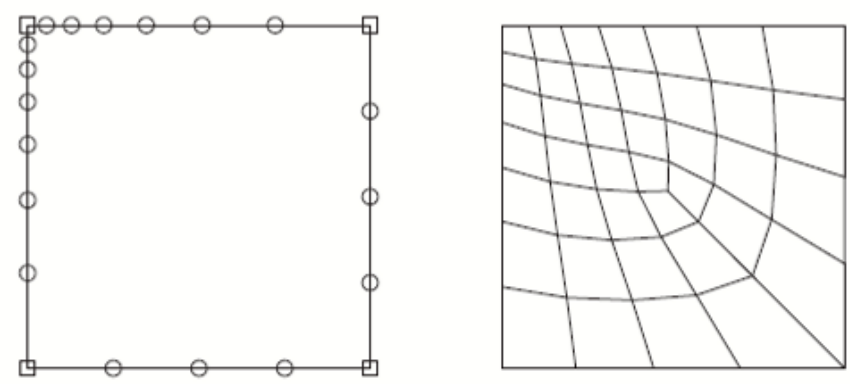

Figura 2.25: Malha customizada pelo usuário a partir de seleção manual de pontos ao longo das extremidades

Se restar dúvida ao usuário quanto à qualidade das malhas adotadas, o Abaqus ainda oferece a opção de avaliá-las antes do processamento, mostrando o grau de qualidade de cada uma através de um código de cores.

\subsection{2}

\section{Modelagem hidráulica - SIMCARR}

No item 1.4 comentou-se que, após a obliteração plena do tubo, a pressão exercida pelo fluido sobre o topo do testemunho está aproximadamente limitada ao diferencial de pressão sobre a esfera que desvia o fluxo. Afirmou-se também que esse diferencial corresponde à soma das perdas de carga nos oríficios de desvio do fluxo e no anular entre o tubo e o barrilete externo. Para estimar essa perda de carga foi utilizado o simulador Simcarr.

O Simcarr é um simulador de hidráulica de perfuração e carreamento de sólidos em poços verticais e inclinados. Capaz de capturar os fenômenos que governam o processo de transporte de sólidos no interior do poço, como a resposta do escoamento anular sólido-líquido, além de outros aspectos importantes no projeto hidráulico [48].

$\mathrm{Na}$ aplicação deste trabalho o Simcarr foi utilizado para reproduzir o escoamento no interior do barrilete de forma análoga à proposição original do software. O anular tubo interno/barrilete foi representado pelo anular coluna/ revestimento com dimensões equivalentes. Os orifícios que desviam fluxo foram representados por jatos de broca de mesma dimensão.

Os resultados de tal simulação são apresentados posteriormente no item 5.2.3. 


\section{3 \\ Metodologia}

\section{1.}

\section{Método de abordagem}

Ao se estabelecer um modelo para o fenômeno do acunhamento, provavelmente a variável de entrada mais importante deste modelo é o coeficiente de atrito entre a amostra e o tubo. Sendo assim, uma etapa importante do trabalho consiste em tentar mensurar este coeficiente.

Para atingir este objetivo foram planejados alguns experimentos. $\mathrm{O}$ primeiro deles, mais complexo, tinha a pretensão de incorporar aspectos próximos aos da situação em campo. Com os obstáculos encontrados em tal experimento os resultados apresentaram razoável nível de incerteza, isso estimulou a realização de um experimento mais simples tentando validar o resultado encontrado no experimento anterior.

Esse segundo experimento, muito mais simples que o anterior, permitiu a incorporação dos fluidos de perfuração e a verificação da influência destes na redução do atrito entre o arenito e o tubo.

Tais coeficientes de atrito para cada tipo de fluido se tornaram então a variável de entrada para os modelos em Elementos Finitos que simulam o arraste da amostra de testemunho no interior do tubo de alumínio.

Como nas situações abordadas neste estudo os deslocamentos entre superfícies são relativamente pequenos, e ocorrem em uma taxa relativamente baixa, limitaram-se os modelos ao atrito estático.

\section{2.}

\section{Experimentos para determinação do coeficiente de atrito}

Determinar o coeficiente de atrito entre o arenito e o tubo de alumínio utilizado para envolver a amostra de rocha durante a testemunhagem consiste em uma parte importante do trabalho. Para tanto, idealizaram-se dois experimentos descritos nos itens a seguir. 
O primeiro deles trata-se da mensuração do esforço necessário para transladar um segmento do tubo de alumínio utilizado na testemunhagem ao redor de uma coluna de areia previamente compactada.

O segundo trata-se de um simples experimento de plano inclinado, onde verifica-se a inclinação necessária para que se estabeleça o deslizamento de uma amostra de arenito repousada sobre o tubo de alumínio. Tal verificação foi repetida em diferentes condições: sem a presença de fluido de perfuração, com fluido de base aquosa e com fluido de base sintética.

\subsection{1. \\ Experimento de translação do tubo envolvendo coluna de areia compactada}

Mais do que apenas determinar o coeficiente de atrito o experimento teria como objetivo avaliar a interação entre a areia e o tubo, uma vez que, conforme explicado anteriormente, há certo dinamismo, a expansão circunferencial da amostra e do tubo depende do esforço axial causado pelo atrito, mas também influenciam na tensão normal entre os dois elementos e consequentemente no próprio atrito.

Para a realização do experimento foram cortados e preparados dois segmentos de um tubo de alumínio normalmente utilizado nas operações de testemunhagem (Figura 3.1). Tais corpos-de-prova foram preparados em dimensões adequadas a serem posicionados abaixo de uma prensa utilizada em ensaios de compressão. Suas extremidades foram faceadas de modo a minimizar imperfeições que causassem distorções e garantissem uma distribuição mais uniforme do carregamento. Foram ainda equipados com rosetas extensométricas, permitindo medir a deformação axial e circunferencial durante o ensaio (Figura $3.2)$. 


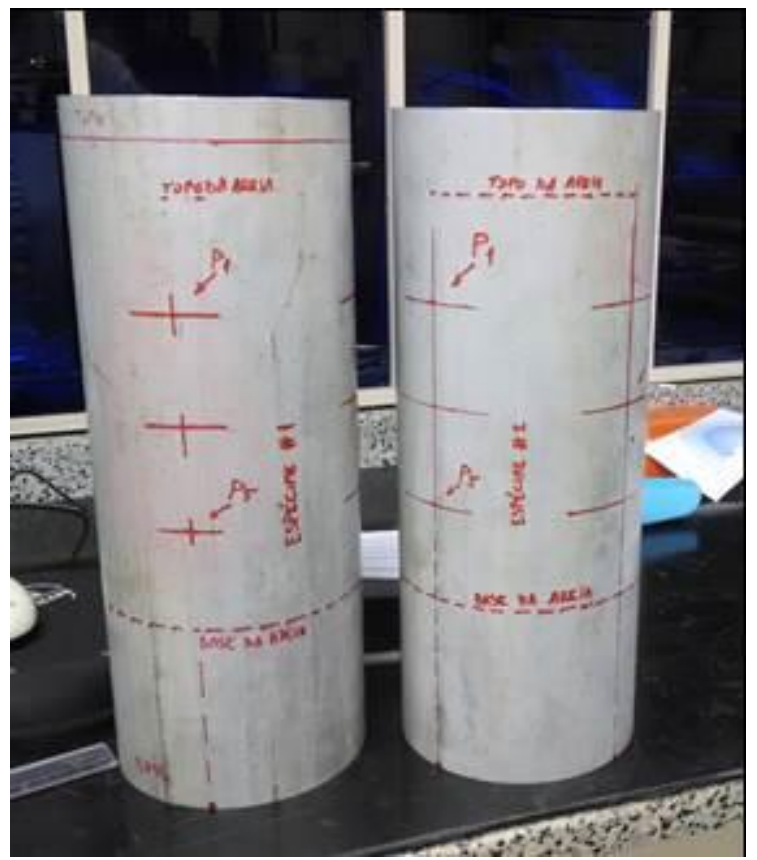

Figura 3.1: Seções dos tubos de alumínio utilizados no interior dos barriletes de testemunhagem

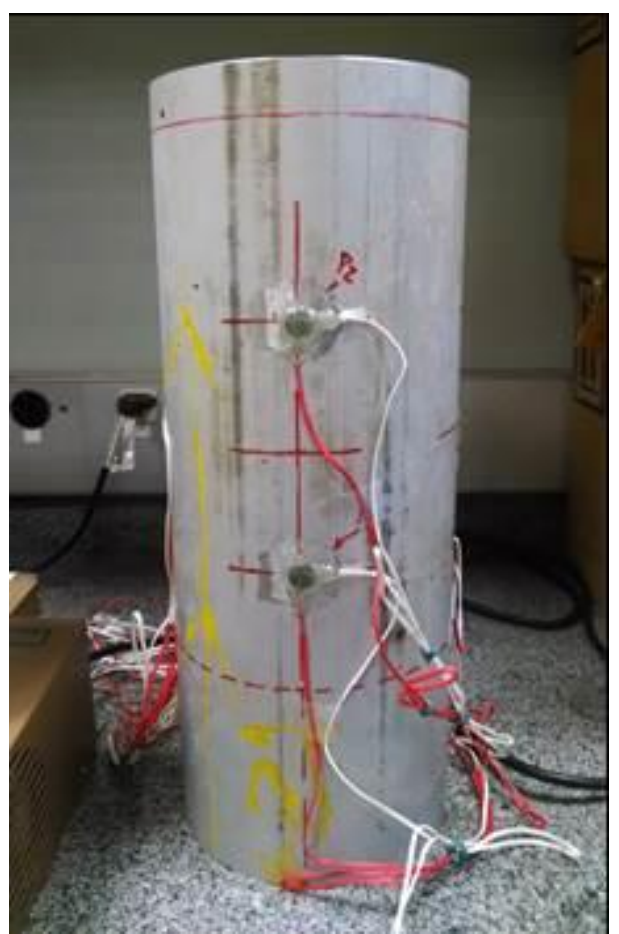

Figura 3.2: Tubos de alumínio após a instalação das rosetas extensométricas

A leitura dos strain gauges circunferenciais permitem determinar indiretamente o grau de compactação aplicado à areia e a tensão normal à parede do tubo exercida por ela. Os strain gauges longitudinais servem para diagnosticar se o esforço aplicado pela prensa está causando flambagem no tubo, alterando os 
resultados. Servem também para verificar a atenuação do esforço longitudinal ao longo do tubo provocada pelo atrito com a areia.

Para a realização do ensaio foram ainda usinadas tampas e êmbolos com dimensões compatíveis aos tubos de alumínio. As primeiras para uma melhor distribuição do esforço aplicado ao tubo na segunda fase do ensaio e impedir que este deslize lateralmente. Os êmbolos servem para permitir a compactação da areia no interior do tubo na primeira fase do ensaio.

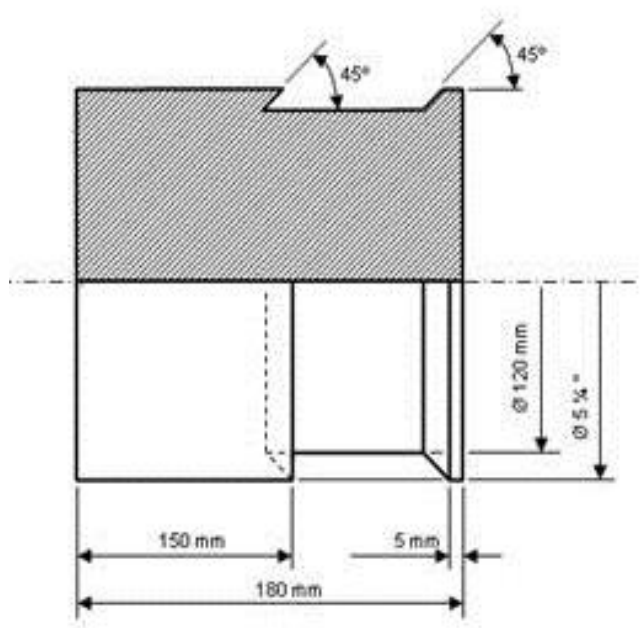

$$
\text { Êmbolo para ensaio do Acurhamerto }
$$

Moteriat Aç

vivos (inax $1 \mathrm{~mm}$ )

Toler áncia \pm 0 . Smen quando nibo especiticads

Quarbisde: 2

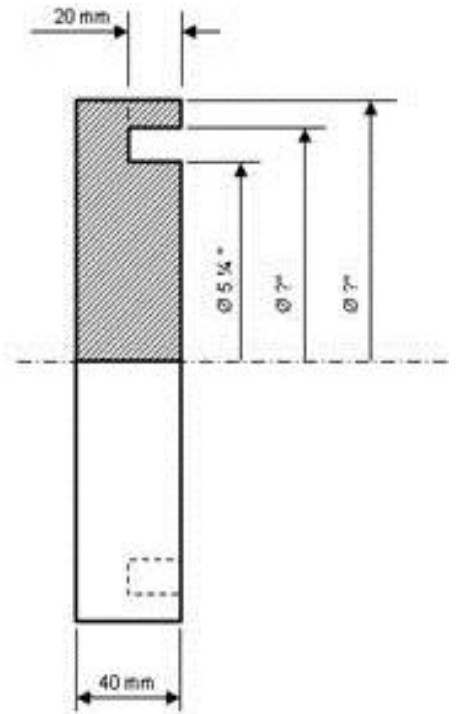

Estojo pora enssio de Acurhantento Msteriat:Aço

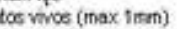
Toler incla: $=0$. Sirn quando nös especificada
Gurtbiade 2

Figura 3.3: Tampas e êmbolos projetados com dimensões compatíveis ao tubo de alumínio selecionado para o experimento. Na figura da esquerda, os trechos cônicos positivo e negativo servem como uma armadilha para aprisionar grãos de rocha que entrem no espaço entre o êmbolo e tubo e que ocasionariam uma parcela resistiva no escorregamento alheia ao atrito areia/parede interna do tubo.

\subsubsection{1.}

\section{Etapas do experimento}

O experimento proposto consistiu em duas fases, repetidas para diferentes níveis de compactação:

1. Fase de compactação: a areia é adensada entre dois êmbolos com a ação da força da prensa. A intensidade dessa compactação influencia a tensão normal que a areia exerce sobre a superfície interna do tubo. Essa tensão normal é inferida através das leituras 
dos strain gauges circunferenciais. Quatro suportes posicionados abaixo do tubo impedem que este sofra movimento descendente. Após a remoção da carga exercida pela prensa, esperava-se que persistisse parte da compactação da areia medida pelo resíduo da deformação circunferencial. A tensão normal calculada a partir dessa deformação residual é a tensão normal considerada na próxima fase do ensaio. A fase de compactação assemelha-se às condições do teste edométrico, mas neste caso não se pode desprezar a elasticidade do tubo de alumínio. Curiosamente, no teste oedométrico o atrito entre o solo e as paredes é uma fonte de incerteza indesejada, e procura-se minimizá-la. Diferente deste experimento, onde mensurar o atrito é exatamente o objetivo.

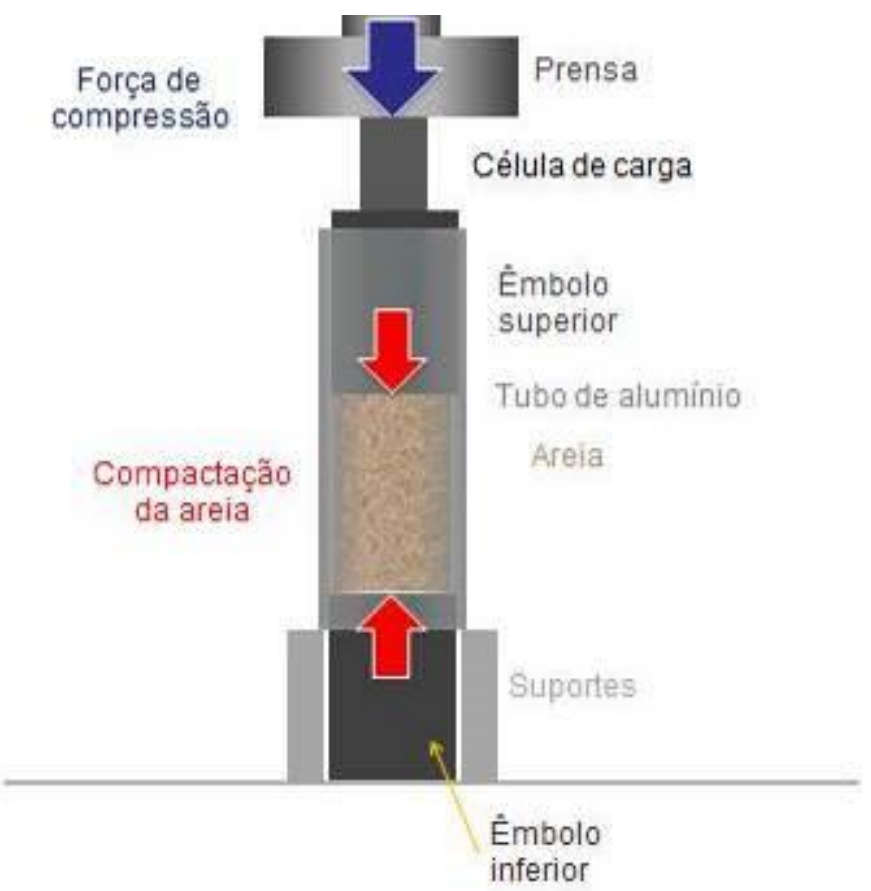

Figura 3.4: Fase de compactação

Para inferir a tensão normal em função da deformação circunferencial medida pelos strain gauges utiliza-se a eq. (2.21), do cilindro de paredes finas. 
2. Fase de deslocamento: após a conclusão da fase anterior, os suportes são removidos, assim como o êmbolo superior. O tubo permanece na posição devido à sua própria interação com a areia. Sobre o tubo de alumínio é posicionada uma tampa de aço de forma a maximizar a distribuição do esforço a ser aplicado pela prensa. É então utilizada a prensa para deslocar o tubo, sendo observado o esforço necessário para superar o atrito estático e movimentá-lo no sentido descendente.

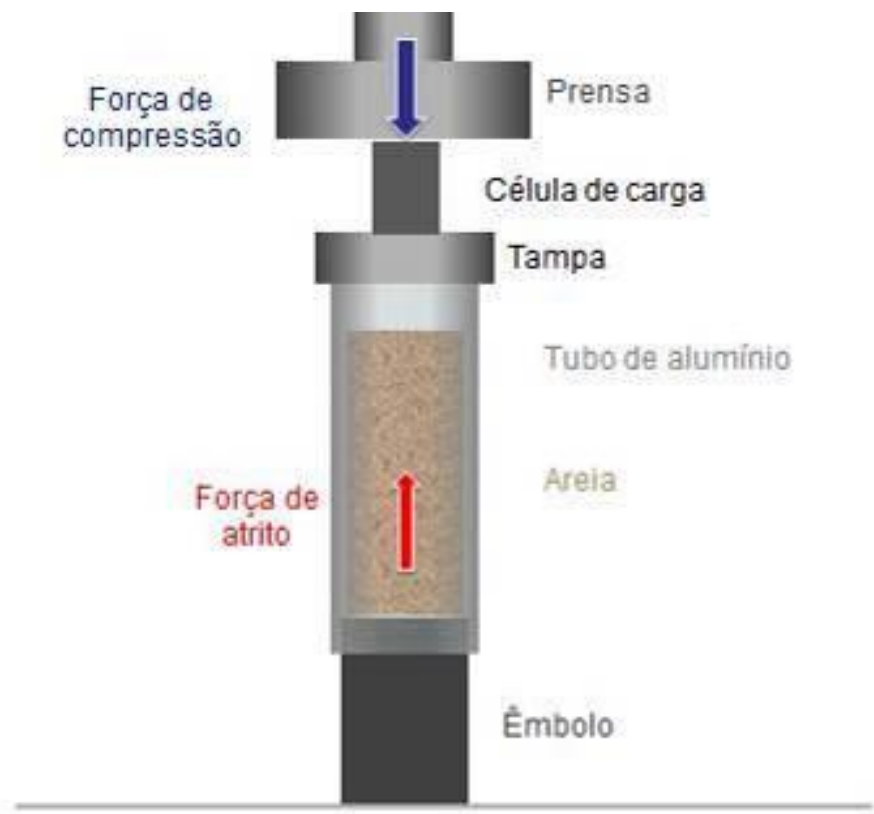

Figura 3.5: Fase de deslocamento ou translação

\subsubsection{2.}

\section{Roteiro de preparação e execução do experimento}

Segue abaixo uma sequência passo-a-passo da preparação e da execução do experimento:

1. Inspecionar o tubo de alumínio e eliminar eventuais irregularidades na superfície interna que possam alterar o resultado do experimento. Por 
se tratar de um tubo utilizado em campo, arranhões ou sujeira agregada ao tubo podem estar presentes. Na impossibilidade de eliminar a irregularidade e traze-lo às condições normais o tubo deverá ser substituído.

2. Cortar o tubo em segmentos com dimensões apropriadas ao seu posicionamento abaixo da prensa a ser utilizada. Refacear suas extremidades.

3. Realizar um ensaio de compressão axial em um segmento de tubo vazio. Os resultados deste ensaio servem para avaliar as propriedades mecânicas do tubo: parâmetros elásticos e limite de escoamento, além de antecipar possíveis dificuldades e não idealidades que serão encontradas na realização do experimento. Tal segmento de tubo deve ser posteriormente descartado.

4. Medir o diâmetro externo, interno e o comprimento do tubo. Como há sistemas de testemunhagem para operações em diferentes fases do poço, com diferentes dimensões, e como há ligeiras diferenças entre os equipamentos de cada companhia de testemunhagem os diâmetros interno e externo não são únicos.

5. Utilizando uma trena e um marcador apropriado, traçar na superfície interna do tubo de alumínio, apenas para referência, circunferências que delimitam o ínicio e o fim do trecho aproximado a ser ocupado pela areia.

6. Marcar na superfície externa do tubo circunferências indicando o posicionamento dos strain gauges a serem instalados.

7. Instalar os strain gauges:

a. Primeiramente, a superfície onde o strain gauge será colado deverá ser lixada em movimentos circulares.

b. Marcar uma cruz que facilite o alinhamento do strain gauge.

c. Espalhar cola sem excesso na superfície posterior do strain gauge e colá-lo observando o alinhamento e comprimi-lo com uma borracha para eliminar qualquer bolha de ar.

d. Soldar os fios aos terminais elétricos do strain gauge.

e. Trançar os fios que posteriormente serão conectados à ponte de Wheatstone. 
f. Cobrir os strain gauges com parafina derretida

8. Pesar o tubo, as tampas, célula de carga, etc

9. Conectar os strain gauges à ponte de Wheatstone soldando os fios aos terminais do módulo de aquisição. Avaliar a qualidade das soldas verificando se a movimentação dos fios provoca uma oscilação substancial no valor medido.

10. Montar o conjunto sobre a bancada:

a. Com auxílio de três ou quatro suportes, posicionar o tubo de alumínio na vertical, encamisando o êmbolo inferior e assentando-o sobre os suportes;

b. Zerar a ponte de Wheatstone;

c. Preencher o tubo com areia até $4 \mathrm{~cm}$ do topo. Distribuir uniformemente a superfície superior da areia;

d. Posicionar o êmbolo superior e a célula de carga.

e. Aproximar a prensa, ajustando o ponto zero para o controle do avanço assim que o contato for verificado, visualmente ou através da observação da leitura da célula de carga.

f. Aplicar a carga em etapas, anotando para cada etapa a leitura de cada strain gauge e o curso da prensa.

g. Após a aplicação da carga total programada iniciar o descarregamento, interrompendo em alguns dos pontos intermediários adotados no carregamento para tomar notas das leituras dos strain gauges.

h. Remover o êmbolo superior após a compactação. Medir a distância entre o topo da areia e o topo do tubo.

i. Verificar e tomar nota da leitura dos strain gauges circunferenciais de modo a mensurar a tensão normal à parede do tubo exercida pela areia compactada no passo anterior.

j. Posicionar a tampa. Avaliar e tomar nota da influência do peso das tampas nas leituras dos strain gauge longitudinais e circunferenciais.

11. Remover os suportes.

12. Enquanto armazena o histórico da leitura dos strain gauges e do esforço e deslocamento da prensa, aplicar esforço lento e gradativo até 
que se observe um súbito deslocamento de maior magnitude indicando a superação do atrito estático. Observar a leitura dos strain gauges. Resultados assimétricos podem indicar a flambagem do tubo de alumínio.

13. Elaborar uma tabela contendo os valores de tensão normal média, tensão axial, deformação axial de cada strain gauge, deformação axial média, deformação circunferencial de cada strain gauge, deformação circunferencial média, deslocamento da prensa.

\subsubsection{3.}

\section{Especificações do sistema de aquisição da deformação}

Transdutor: Rosetas extensométricas $90^{\circ}$ Kyowa, $120 \pm 0,4 \Omega$

Módulo de aquisição (ponte de wheatstone, filtros, conversor A/D): HBM

Quantum MX840A c/ 8 entradas; conversor A/D de 24 bits; conectado ao PC via Ethernet (ver Figura)

Software: HBM Catman Express

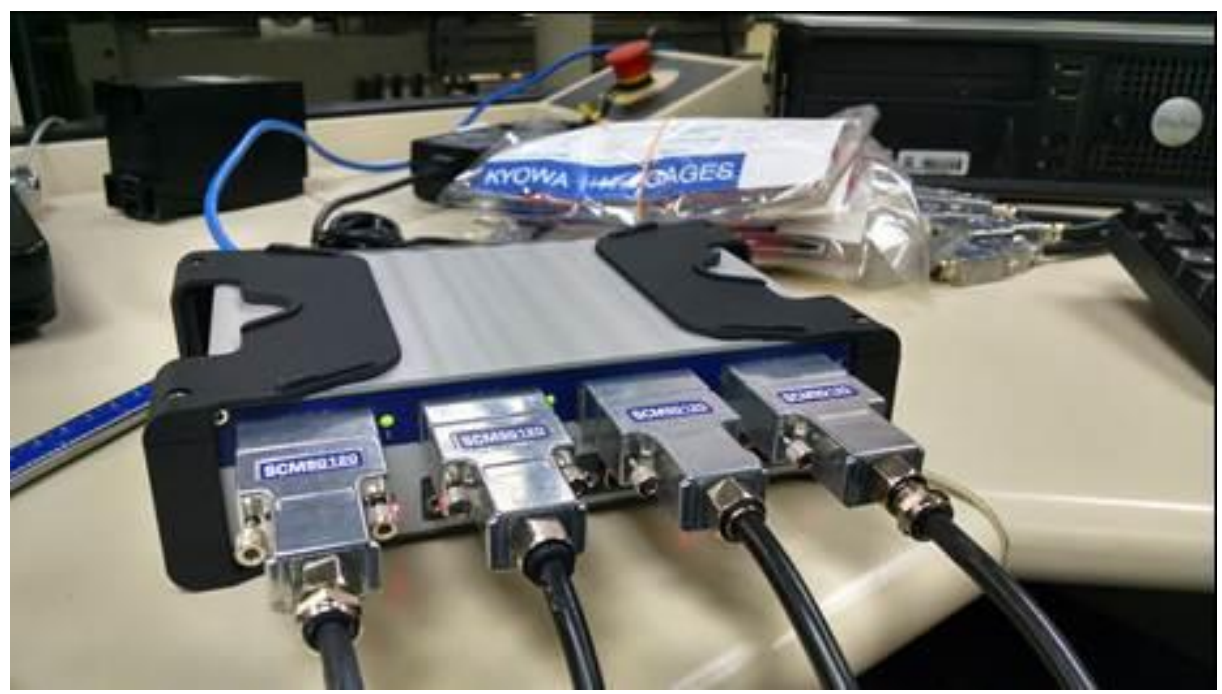

Figura 3.6: Módulo de aquisição com ponte de Wheatstone 


\subsubsection{4.}

\section{Propriedades da areia utilizada}

Para o experimento utilizou-se areia de praia predominantemente siliciclástica. Uma peneira com tela de espaçamento mesh 12 foi utilizada, sem a pretensão de selecionar a granulometria da areia, somente para a eliminação dos detritos.

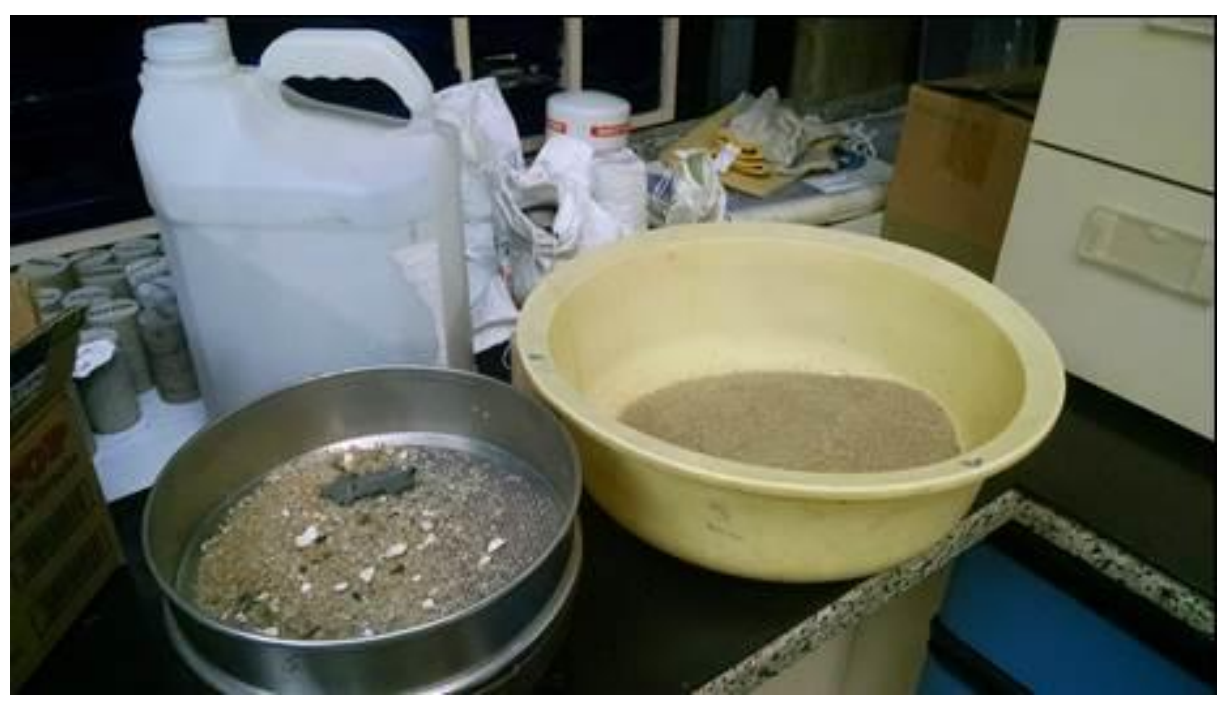

Figura 3.7: Eliminação das impurezas na areia utilizada

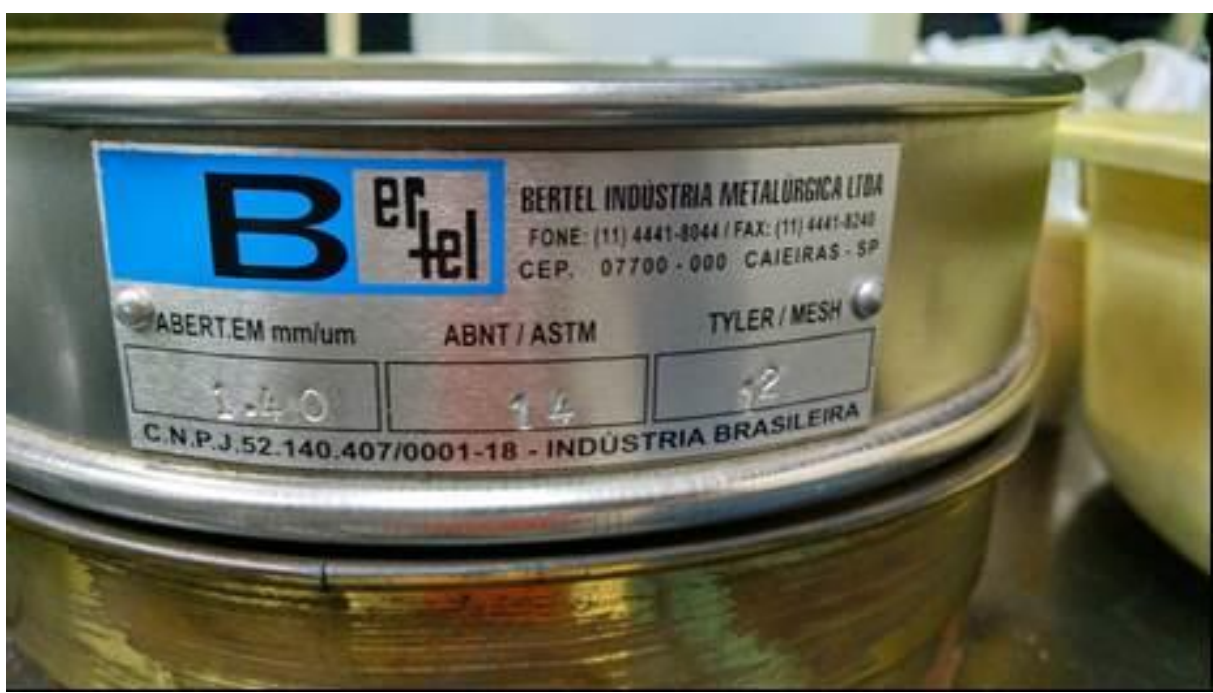

Figura 3.8: Peneira mesh 12, utilizada na limpeza da amostra de areia 
O volume de $1000 \mathrm{~cm}^{3}$ da areia em questão, antes de sua compactação, apresenta uma massa de $1572 \mathrm{~g}$, ou seja, um peso específico seco aparente de $1,572 \mathrm{~g} / \mathrm{cm}^{3}$.

A partir dos dados anteriores e considerando que areia apresente apenas grãos de quartzo $(G=2,65)$ em sua grande maioria, podemos estimar a porosidade original da areia fofa:

$$
\gamma_{\mathrm{dry}}=\mathrm{G}^{*} \gamma_{\mathrm{w}}(1-\Phi)
$$

$$
\Phi=1-\left(\frac{\gamma_{\mathrm{dry}}}{\mathrm{G} \cdot \gamma_{\mathrm{w}}}\right)
$$

$1-(1,572 /(2,65.0,98)=0,395$

O volume inicial de areia utilizado é de $3268,5 \mathrm{~cm}^{3}(22,5 \mathrm{~cm}$ de altura em um tubo com diâmetro interno de 13,6 cm).

Os parâmetros elásticos da areia foram determinados experimentalmente conforme descrito nos sub-capítulo 4.1.5.

\subsubsection{5.}

\section{Dimensões e posicionamento}

A Figura 3.9 mostra as principais dimensões do conjunto, incluindo a distância dos strain gauges em relação à extremidade inferior do segmento de tubo. As rosetas extensométricas instaladas no tubo estão distribuídas em três diferentes seções $(16,21,5$ e $27 \mathrm{~cm}$ da extremidade inferior). Cada seção contêm um par de rosetas extensométricas diametralmente opostas. A seção do par de rosetas extensométricas intermediário (posicionados a $27 \mathrm{~cm}$ ) estão defasados em $90^{\circ}$ das demais.

Na nomenclatura adotada nesse trabalho chama-se de P1 e P2 as posições de rosetas extensométricas da seção superior, P3 e P4 da seção intermediária e P5 e 
P6 da seção inferior. Quando seguidos de uma letra, esta indica a direção da leitura do strain gauge, ou seja, P3C representa a leitura de deformação circunferencial na posição 3, P3L representa a leitura de deformação longitudinal na mesma posição.

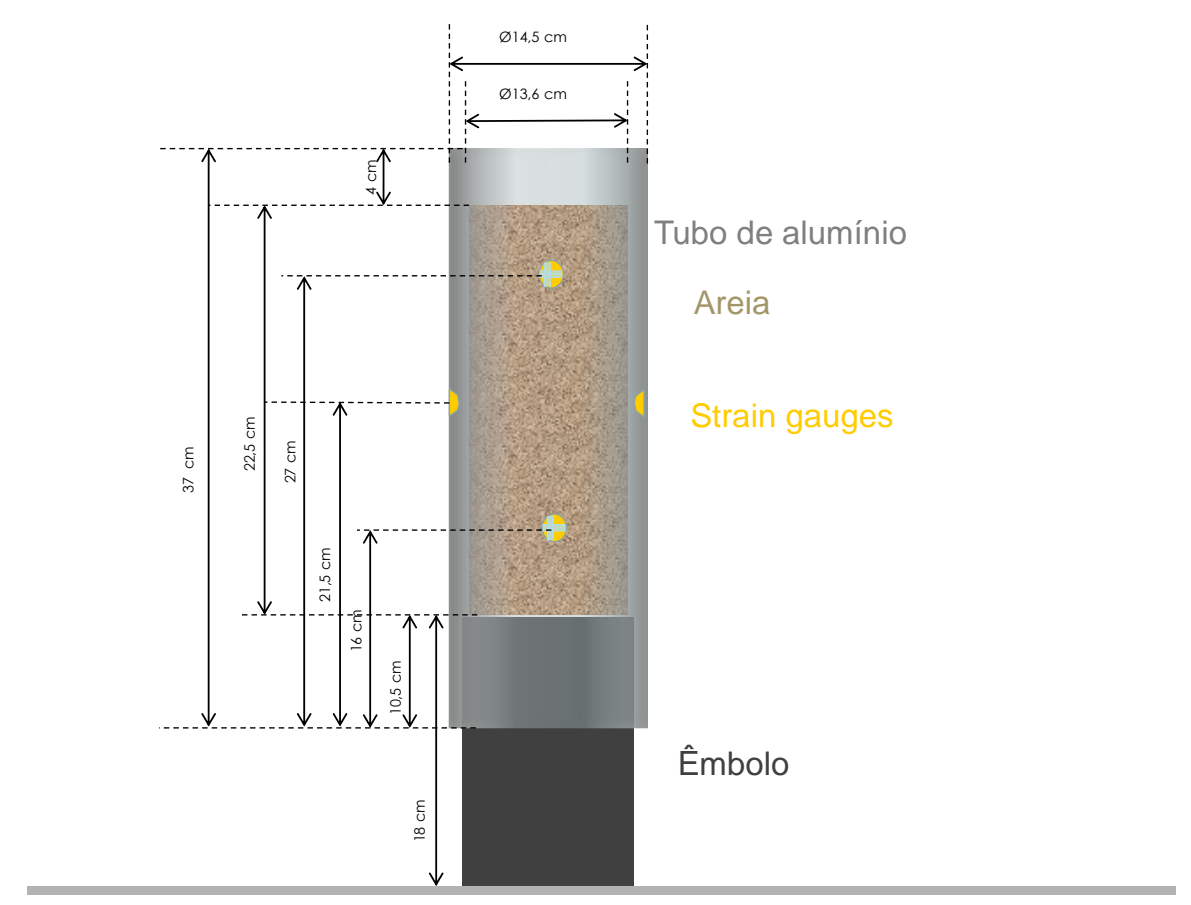

Figura 3.9: Dimensões do aparato e posicionamento dos strain gauges

A figura anterior representa as dimensões do espécime no início do ensaio. Cabe ressaltar que o topo da areia, padronizado para iniciar a $4 \mathrm{~cm}$ do topo do tubo, tenderá a rebaixar à medida em que a areia for compactada.

Curso da máquina: $50 \mathrm{~cm}$

Comprimento do êmbolo: $18 \mathrm{~cm}$

Massa das tampas: 5,9 e $5,8 \mathrm{~kg}$

Propriedades mecânicas teóricas do tubo de liga de alumínio. Dados do fabricante: 
Módulo de Elasticidade: $70 \mathrm{GPa}$

Coeficiente de Poisson: 0,33

Tensão de escoamento: $255 \mathrm{MPa}$

Dimensões do tubo de testemunhagem utilizado:

Diâmetro externo: $144,79 \mathrm{~mm}(5,7$ in)

Diâmetro interno: 137 mm (5,39 in)

Área da seção transversal: 2,7 in ${ }^{2}$

Dimensões do segmento de tubo para teste de determinação de parâmetros elásticos:

$\mathrm{L}=105,25 \mathrm{~mm}$

$\mathrm{D}=145,15 \mathrm{~mm}$

Lista de material utilizado:

- Tubo de alumínio

- Strain gauges

- Desengraxante

- Cola araldite

- Parafina ou verniz de proteção

- Fios

- Lixas, Grana 320 e Grana 400

- Fita adesiva

- Trena

- Marcador

- Areia 
- Suporte para o êmbolo

- Suporte para o tubo de alumínio

- Êmbolos

- Tampas

- Estação de solda

- Estanho

- Fita isolante

- Estilete

\subsection{2.}

\section{Experimento do plano inclinado}

Para a execução do experimento do plano inclinado, um segmento do tubo de alumínio foi parafusado a uma base, permitindo sua gradativa inclinação (Figura 3.10).

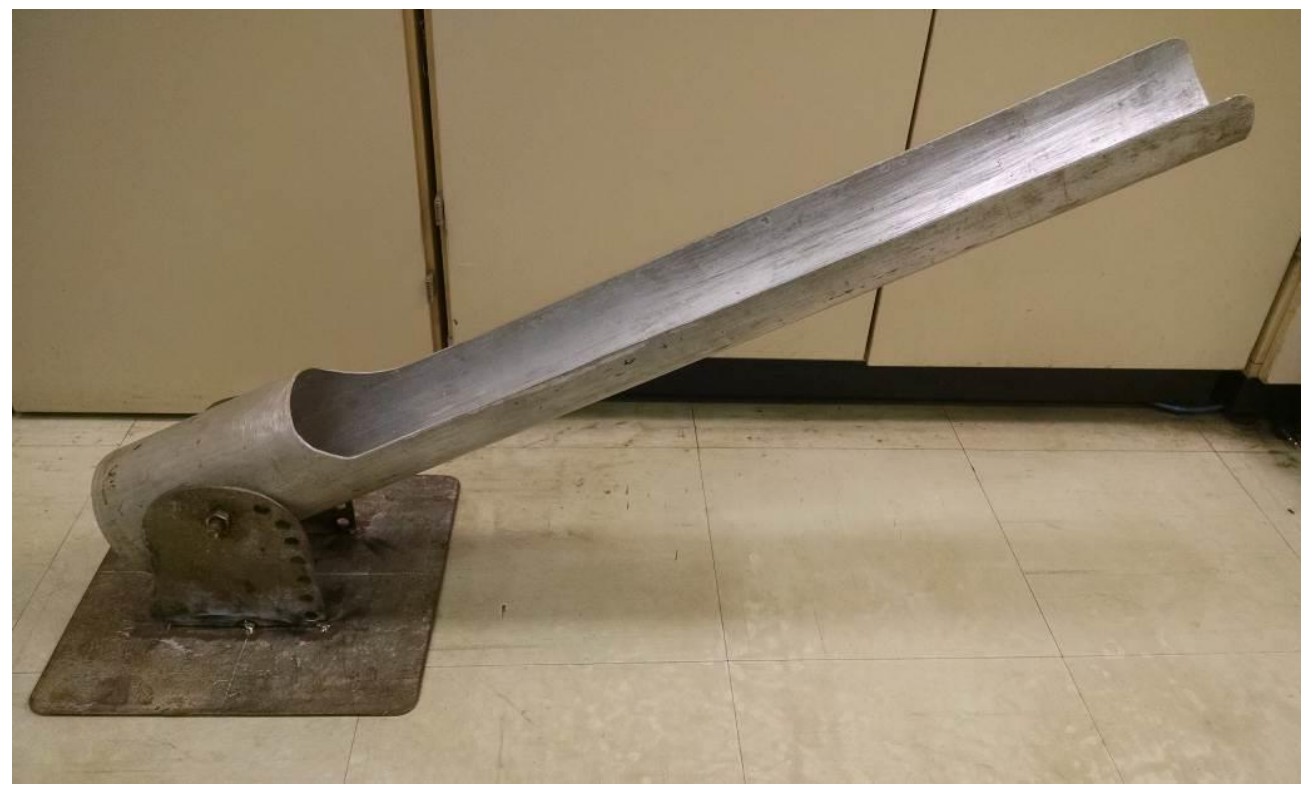

Figura 3.10: Aparato construído para realização de tilt test avaliação do coeficiente de atrito entre a amostra de arenito e o tubo

Foi selecionada uma amostra de arenito da Bacia de Campos de comprimento aproximado de $18 \mathrm{~cm}$ e massa de $478 \mathrm{~g}$ (Figura 3.11). A amostra consiste em parte de uma seção transversal de $1 / 3$ do diâmetro original do testemunho (4 polegadas), e por isso possui uma face plana em oposição à 
curvatura externa. Optou-se pela amostra de um arenito consolidado de modo a minimizar sua desagregação ao deslizar.

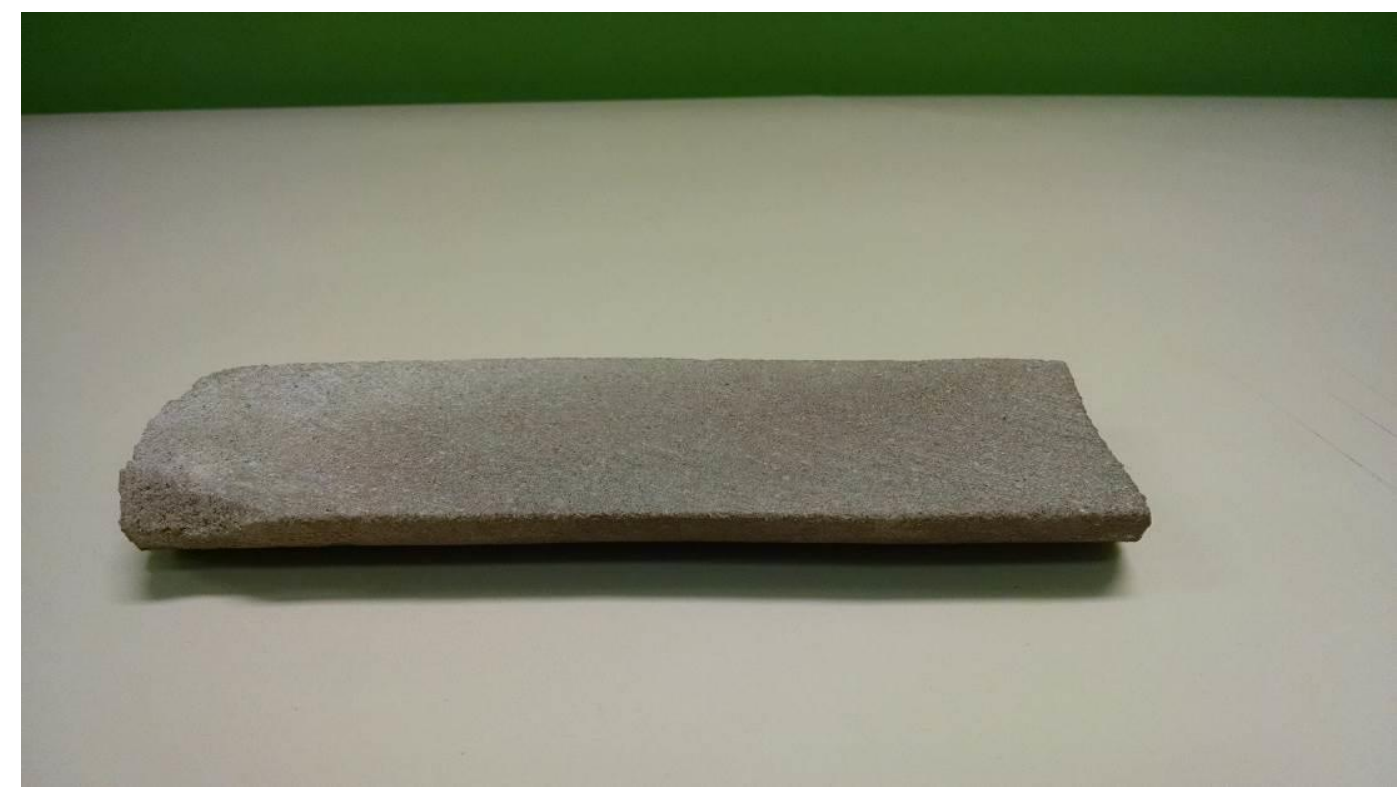

Figura 3.11: Amostra de arenito utilizada no experimento

Além de ensaios com a superfície seca, foram realizados também com a aplicação de película de três diferentes fluidos de perfuração: SCOL, FPA polimérico com goma xantana e Oledrill.

1. SCOL: fluido de perfuração com base aquosa desenvolvido pela Petrobras. A sigla que compõe seu nome tem origem em seu detalhamento: fluido Salgado $(\mathrm{NaCl}$ e/ou $\mathrm{KCl})$, tratado com polímero Catiônico, sólidos Obturantes e Lubrificantes. A concepção deste fluido foi destinada originalmente para a perfuração de poços direcionais ou horizontais. Para as fases de reservatórios sua composição é alterada para se adequar aos requisitos dos fluidos "drill-in", que têm em sua composição apenas componentes passíveis de serem atacados por ácidos, oxidantes ou enzimas. Esta preocupação visa resguardar o reservatório de possíveis danos a formação, causado por aditivos do fluido que não sejam passíveis de remoção na fase de completação do poço. A composição do fluido apresentava dois inibidores de argilas: o próprio $\mathrm{KCl}$ e um produto 
catiônico. O uso de lubrificantes, que no passado era imperativo quando se perfurava com motor de fundo, hoje em dia se tornou facultativo com o uso das modernas ferramentas de perfuração direcional. A composição do fluido utilizado não apresentava lubrificantes.

Viscosidade plástica típica na temperatura ambiente: 30 a 40 cP.

2. FPA polimérico com goma xantana: Fluido de perfuração aquoso de composição muito simples, usado muitas vezes na perfuração de fases iniciais do poço onde não existe preocupações com inibição de argilas, ou na perfuração de zonas salinas, sendo que neste caso se usa salmoura saturada na composição. A amostra em questão foi utilizada para a perfuração de uma zona de sal e tinha como principais características o fato de ser uma salmoura saturada, viscosificada com goma xantana e adensada com baritina. Embora esse tipo de fluido normalmente tenha na sua composição básica o PAC (celulose poli-aniônica) como redutor de filtrado, neste caso não havia por ter sido utilizado na perfuração de uma formação impermeável, onde o controle do filtrado não se faz necessário.

Viscosidade plástica típica na temperatura ambiente: 30 a 40 cP.

3. Oledrill: fluido sintético composto de emulsão com base de olefinas. A Petrobras utilizou os chamados fluidos à base óleo em suas perfurações marítimas até o ano de 1988, quando seu uso foi descontinuado. Devido a utilizar óleo diesel como base, o fluido era considerado tóxico. Na década de 90, o incremento das perfurações de poços horizontais, forçou a Petrobras a rever a questão dos fluidos a base óleo, utilizando, em substituição, bases orgânicas mais amigáveis. Iniciou então nessa época o uso dos agora chamados fluidos de base sintética. A Petrobras desenvolveu a formulação do fluido que ficou conhecido como BRMUL. Este fluido utilizava uma corrente da refinaria RLAM, formada por parafinas lineares com 
tamanho entre C13 e C16. No final de 2013 o IBAMA e a Petrobras, assinaram o plano de monitoramento de fluidos e cascalhos (PMFC), que continha nova diretriz para a utilização de fluidos, e incluía novos testes de toxicidade e biodegrabilidade. $\mathrm{O}$ resultado foi que as parafinas passaram a não atender os requisitos ambientais. Foi dado um prazo até setembro de 2016, para que a Petrobras realizasse a transição da base parafina para outro produto que atendesse os novos requisitos. Após pesquisa no mercado, o produto que melhor atendia os requisitos do IBAMA, que atendesse tecnicamente a formulação dos fluidos e que tivesse disponibilidade no mercado seriam as olefinas. Desde setembro de 2014, são utilizadas somente olefinas nas formulações de fluido sintético. Embora através dos tempos a composição dos fluidos não aquosos tenha mudado, a característica base não mudou substancialmente. Todos os fluidos se tratam de uma emulsão de salmoura de cloreto de sódio ou cloreto de cálcio em uma base orgânica. A característica principal é se tratar de uma emulsão de água em óleo, ou seja, a fase externa é sempre o óleo. O fato da fase externa ser o óleo visa impedir a hidratação das argilas, pois as mesmas não entram em contato com água. Outra característica é a melhor lubricidade.

Viscosidade plástica típica na temperatura ambiente: 40 a $70 \mathrm{cP}$.

\section{3.}

\section{Modelagem do caso real através do MEF}

Para tentar estabelecer um modelo de previsão para o acunhamento em função da resistência da rocha, e ainda avaliar a influência de determinados fatores na ocorrência desse fenômeno, novamente foi utilizado o MEF.

Foi criado um modelo com uma lógica bem simples e com apenas três elementos: o tubo, a amostra de testemunho, um segundo tubo inferior simulando o engastamento do cilindro de testemunho ao fundo do poço. Isso porque na 
situação real o trecho não confinado da amostra de testemunho se resume a cerca de $15 \mathrm{~cm}$ abaixo da sapata do tubo interno (ver item 2.2).

A dinâmica consistiu em monitorar a progressão dos esforços sobre o trecho não confinado da amostra de testemunho na medida em que esta gradativamente transladava, adentrando o tubo superior.

Foram desenhados o tubo e amostra com um comprimento de apenas $2 \mathrm{~m}$, mesmo que na prática os resultados seriam comparados, em alguns casos, com os resultados de testemunhagens com extensão superior. A principal razão para isso é que se julgou que $2 \mathrm{~m}$ de translação após o contato seriam suficientes para determinar o comportamento do aumento do arraste.

Nas simulações, foram utilizados os coeficientes de atrito estimados no capítulo seguinte para operações com fluido base água e base sintética. Foram criados modelos em duas dimensões diferentes comportando os sistemas para amostras de 4 e 5,25 polegadas, e executadas simulações com diferentes carregamentos no topo, reproduzindo a resistência provocada pelo deslocamento do fluido de perfuração. 


\section{Execução e Resultados dos Experimentos}

\section{1. \\ Experimento de translação do tubo através de coluna de areia compactada}

\subsection{1.}

\section{Ensaio-teste destrutivo em um segmento de tubo vazio}

Antes do experimento para a determinação do coeficiente de atrito, realizouse um ensaio de compressão axial em um segmento de tubo vazio. Uma das intenções era a de familiarizar-se com a operação da prensa e obter experiência para determinar os parâmetros e metodologia do ensaio principal. Um exemplo disso é a taxa de carregamento adequada para o experimento $(0,3 \mathrm{kN} / \mathrm{s})$. Adicionalmente, tal ensaio serviu para verificar experimentalmente se os parâmetros elásticos da liga alumínio que compõe o tubo confirmariam os valores teóricos.

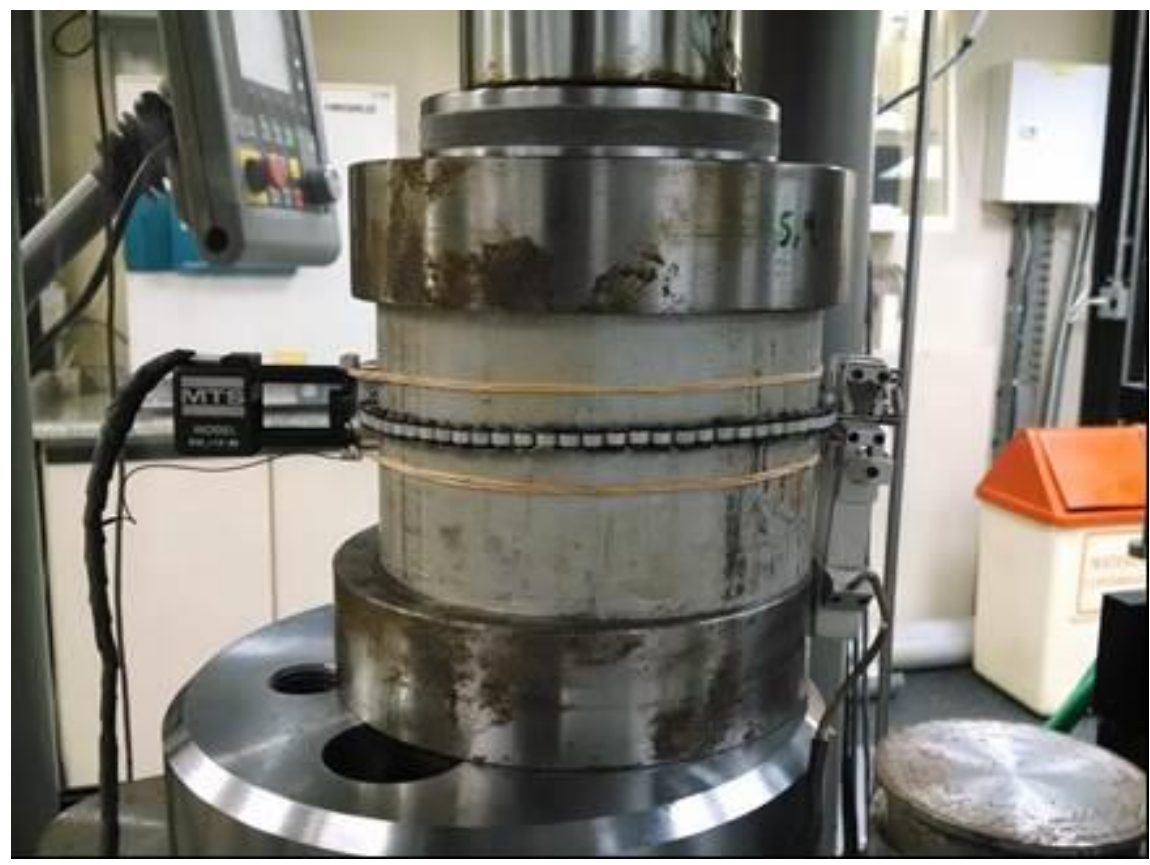

Figura 4.1: Amostra de tubo de alumínio instrumentada para ensaio de compressão uniaxial

Como se pretendia atingir o escoamento do material não era possível realizar este ensaio nos mesmos espécimes que posteriormente seriam utilizados 
no ensaio principal. Além disso, com um nível de carregamento elevado um espécime muito longo poderia apresentar um erro considerável devido à flambagem. Utilizou-se então neste ensaio um segmento do tubo de cerca de 20 $\mathrm{cm}$ de comprimento, devidamente faceado assim como os segmentos utilizados no ensaio principal. Posicionou-se o segmento na prensa, equipado com um extensômetro circunferencial de corrente para medir a deformação circunferencial. Do próprio sistema da prensa e sua célula de carga obtiveram-se os dados de deslocamento do pistão (utilizado na determinação da deformação axial) e o esforço aplicado.

Para a determinação do módulo de elasticidade, selecionou-se um trecho visto como mais estável. Livre da fase inicial de acomodação da superfície da prensa sobre o tubo e também distante da fase não linear. Os dados experimentais indicaram um módulo de elasticidade de aproximadamente 70,6 GPa, conforme o gráfico "tensão x deformação" exibido na Figura 4.2.

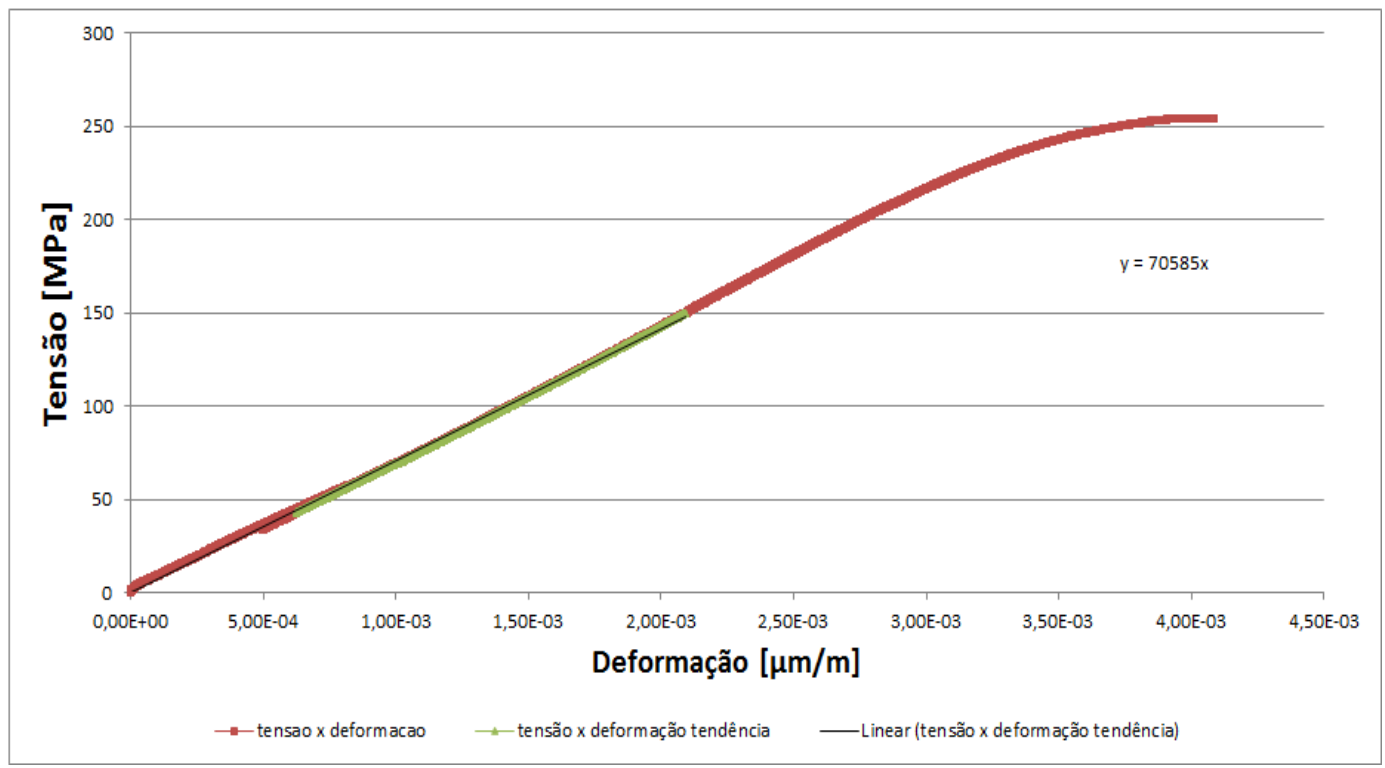

Figura 4.2: Tensão x Deformação para ensaio de compressão uniaxial em tubo de alumínio com diâmetro de 5,25 in $[\mathrm{MPa}]$

Nota-se ainda no gráfico anterior, que o limite de escoamento do material, quando o gráfico inicia uma trajetória não linear indicando o início da deformação plástica do material, ocorreu em tensão axial da ordem de $250 \mathrm{MPa}$. Valor este condizente com o valor teórico para a liga de alumínio em questão. 
O parâmetro que apresentou discrepância em relação ao que era esperado foi a relação entre a deformação lateral e a deformação axial. Em nenhum momento este parâmetro se manteve constante próximo do valor teórico do coeficiente de Poisson do material $(0,33)$. Desconsiderando os valores erráticos do início do carregamento, tal relação se manteve inicialmente oscilando por volta de 0,40 e então aumentou na medida em que se aumentava o carregamento, chegando a ultrapassar o valor unitário, indicando uma deformação circunferencial ainda maior que a deformação axial. Tal comportamento pode ser explicado por uma não-linearidade geométrica, um "embarrigamento" do tubo em sua parte central, ou mesmo por uma acomodação da extensometria circunferencial.

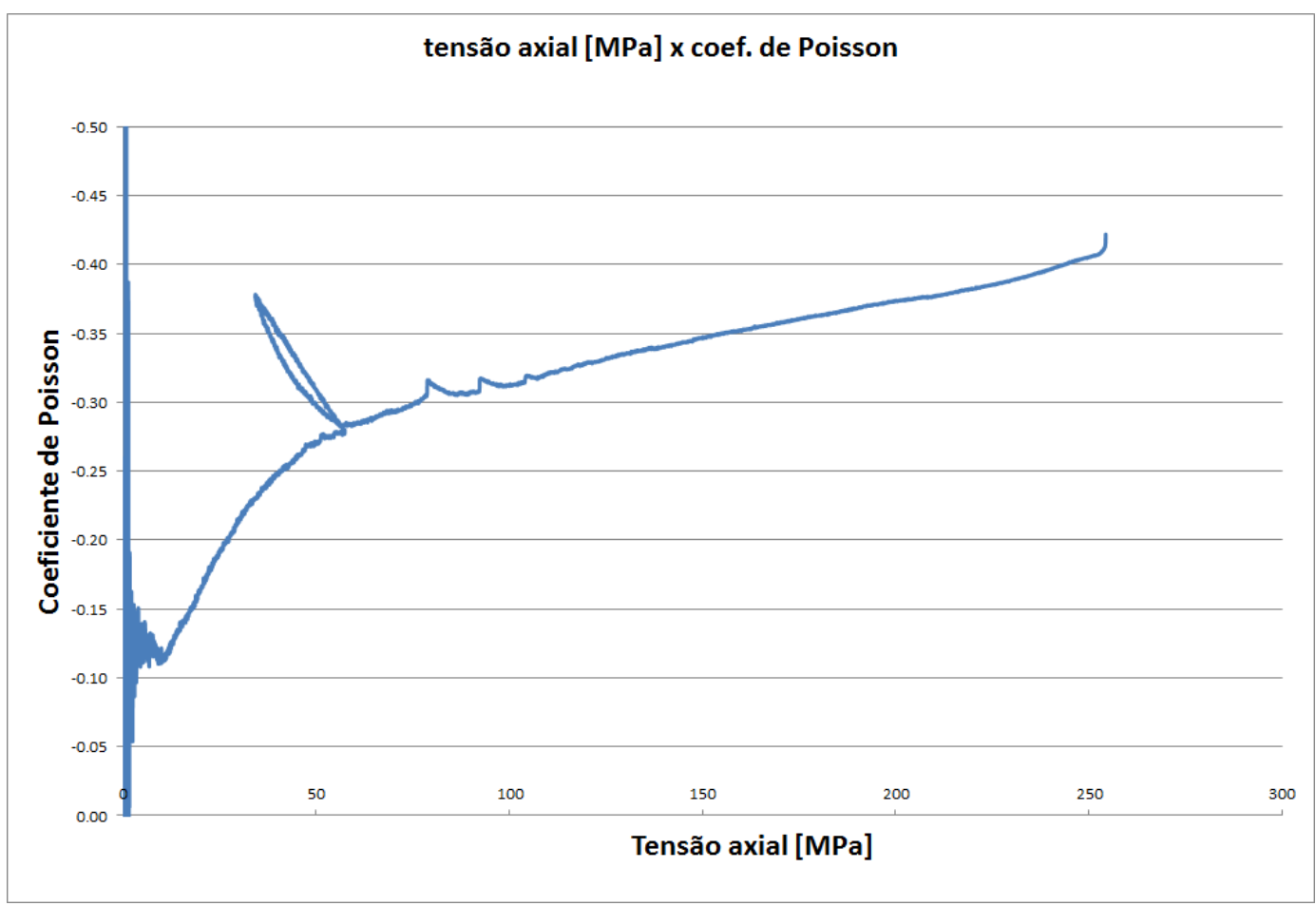

Figura 4.3: Diagrama da relação entre as deformações lateral e axial (Poisson) em função da tensão axial $(\mathrm{MPa})$ no tubo de alumínio 


\subsection{2.}

\section{Ensaio-teste no tubo de alumínio instrumentado com strain gauges}

Após a instalação dos strain gauges nos espécimes havia a dúvida se estes apresentariam medições coerentes. Desta forma um novo ensaio de compressão com o tubo vazio, desta vez não destrutivo, foi executado. Neste ensaio utilizou-se a prensa para aplicar em estágios uma força no sentido axial do tubo, enquanto se media a deformação longitudinal e circunferencial em cada roseta extensométrica.

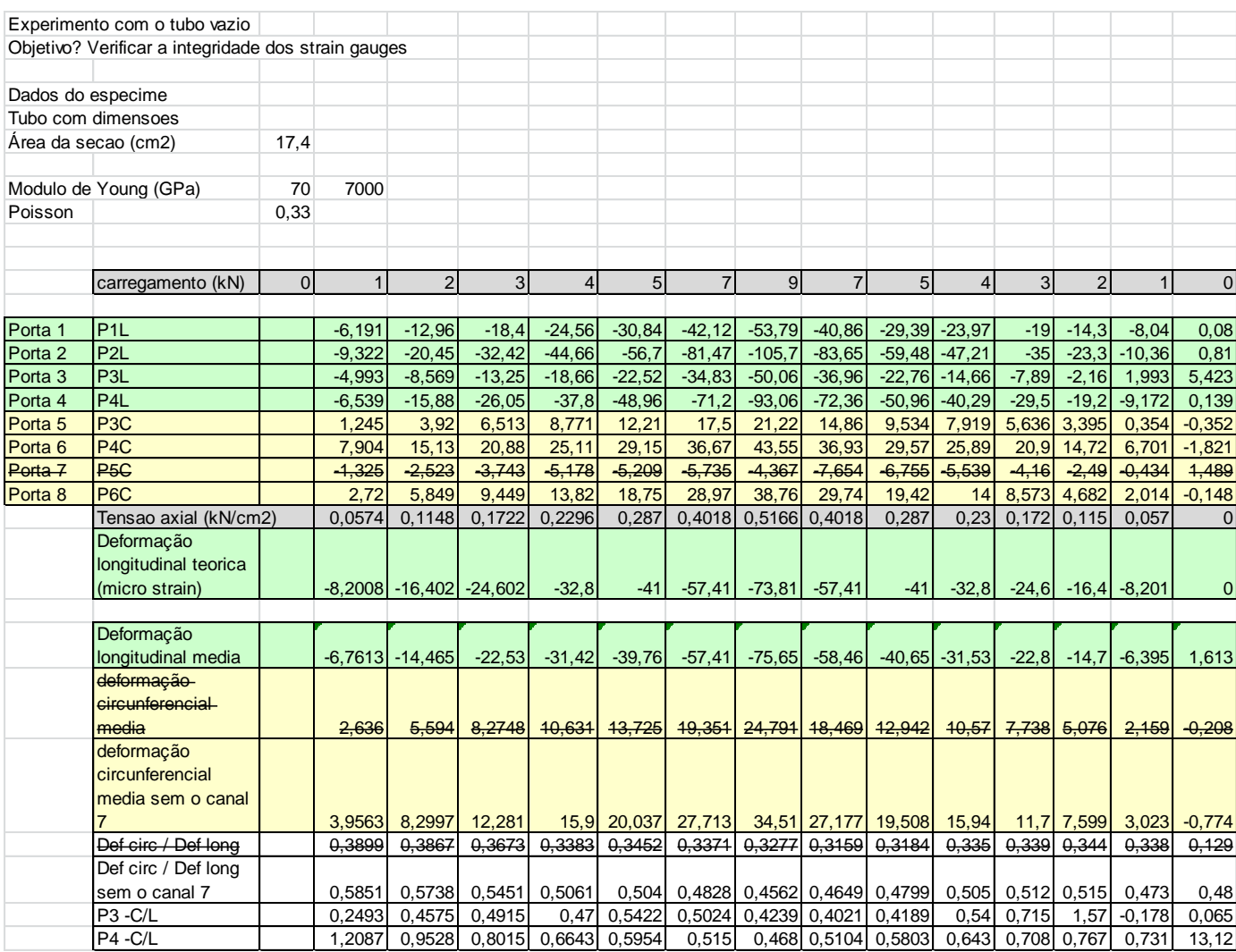

Tabela 1: Resultados da deformação medida pelas rosetas extensométricas durante carregamento axial sobre o tubo vazio

Ao analisar os resultados após o ensaio constatou-se que o canal 7 (P5C) infelizmente apresentou leituras incoerentes, sendo desta forma desconsiderado.

A partir da análise dos resultados, considerando os valores médios de deformação axial e a tensão aplicada, constata-se que os resultados obtidos são muito próximos da deformação axial teórica, calculada a partir do módulo de Young teórico para a liga de alumínio. 
No entanto, novamente a relação entre a deformação circunferencial e axial não se mantém próxima de 0,33 , tanto para os valores médios de deformação, quanto se analisarmos as leituras das rosetas extensométricas nas posições P3 e P4 individualmente (ver na tabela as linhas $\mathrm{P} 3-\mathrm{C} / \mathrm{L}$ e $\mathrm{P} 4-\mathrm{C} / \mathrm{L}$ ), únicas rosetas onde estavam sendo adquiridas as leituras de deformação longitudinal e circunferencial simultaneamente. Tal relação se manteve na faixa próxima a 0,4 ou 0,5 , ou seja, uma deformação circunferencial por volta da metade do valor da deformação axial.

Voltando novamente a atenção aos resultados da deformação longitudinal, cabe ressaltar que, apesar de seu valor médio concordar com valores estimados a partir de valores tabelados para o material, tais medições apresentaram razoável dispersão nos diferentes pontos do tubo, indicando excentricidade no carregamento. Uma das possíveis causas é a irregularidade na geometria do tubo (ao se medir os diâmetros interno e externo dos espécimes constatou-se que possuem seção transversal ligeiramente ovalada), fazendo com que na média se apresente bem comportado, mas que pontualmente apresente pontos com maior ou menor concentração de tensões. Outra possibilidade é a de que, embora dedicado todo um cuidado com relação a isso, o faceamento das extremidades do tubo não esteja perfeito.

De qualquer forma considerou-se este ensaio positivo, pois a proximidade de seus resultados com os valores teóricos de deformação axial eliminou suspeitas acerca da qualidade da instalação dos strain gauges.

\subsection{3.}

\section{Execução do experimento de translação do tubo através da areia compactada}

Antes da execução do experimento, um longo tempo foi dedicado a minimizar a incerteza de medição dos strain gauges. Os pares de fios foram trançados, de modo a minimizar a interferência eletro-magnética expúria, uma vez que a variação na resistência elétrica do strain gauge provocada pela deformação é mínima, e mesmo uma pequena diferença de potencial induzida sobre o par de fios pode alterar o resultado medido, principalmente porque os fios em questão 
possuíam um comprimento considerável, por volta de um metro. As soldas entre os fios de cada strain gauge e os terminais do módulo de aquisição de dados foram refeitas diversas vezes, até que se observasse uma reduzida oscilação na medição ao se movimentar os fios.

Após o ajuste do zero a leitura dos strain gauges mantinham uma oscilação na faixa de $\pm 2 \mu \mathrm{m} / \mathrm{m}$ Adicionalmente, uma variação gradativa e sistemática na leitura dos strain gauges foi observada. Após o ajuste de zero da ponte de Wheatstone observava-se após algumas dezenas de minutos todos medindo, por exemplo, 5 ou $-5 \mu \mathrm{m} / \mathrm{m}$, indicando uma tendência em tal variação. A princípio acreditava-se ser uma questão de estabilização térmica de todo o sistema, entretanto mesmo mantendo o circuito energizado por um período de várias horas esse comportamento não cessou.

Considerando apenas os efeitos mencionados no parágrafo anterior, mesmo sem considerar demais fontes de incerteza, podemos dizer que a componente da incerteza da medição da deformação gerada no ajuste do zero é de cerca de 10 $\mu \mathrm{m} / \mathrm{m}$.

\subsubsection{1. Fase de compactação da areia}

A fase de compactação da areia foi executada seguindo o procedimento descrito no sub-capítulo 3.2.1.2. Alguns arranjos foram necessários, uma vez que a célula de carga da prensa estava inoperante, e a substituta possuia dimensões diferentes. Desta forma uma rótula da prensa foi removida de modo a permitir acomodar o tubo com areia sob quatro suportes de 7,5 cm, o êmbolo superior e a célula de carga.

Foram realizados uma série de ensaios com força aplicada de 20, 50 e 80 $\mathrm{kN}$. Considerando a área da seção tranversal da coluna de areia $\left(145,19 \mathrm{~cm}^{2}\right)$, isso representa uma tensão vertical de 1,38, 3,44 e 5,51 MPa, respectivamente.

Apesar do cuidado em distribuir uniformemente a superfície superior da areia, se observou que no início do ensaio o êmbolo superior iniciava ligeiramente desalinhado em relação à prensa e também ao tubo. No decorrer do ensaio, com a aplicação de uma carga maior o êmbolo se realinhava, no entanto tal fato pode ter 
estimulado alguma assimetria nas medições, além da suposta irregularidade na geometria do tubo indicada pelos resultados do ensaio com o tubo vazio.

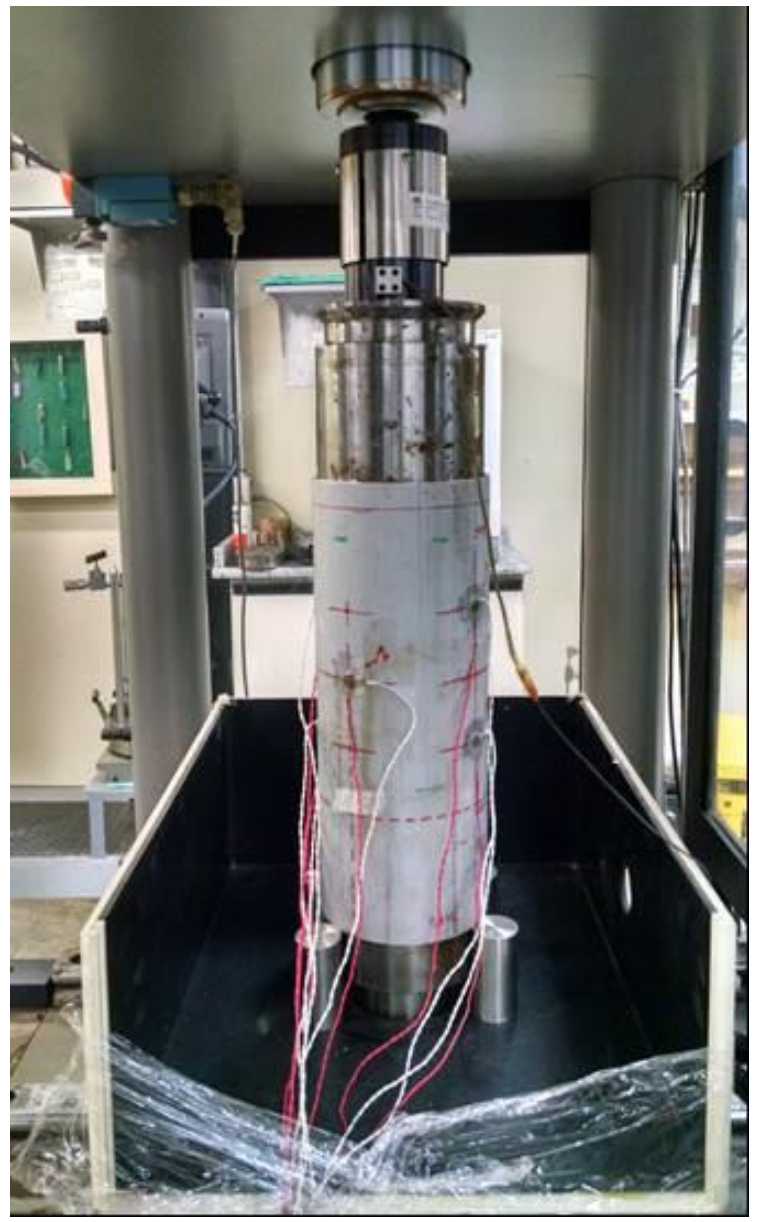

Figura 4.4: Tubo de alumínio instrumentado para fase de compactação da areia

\subsubsection{2.}

\section{Fase de translação do tubo}

Para a fase de translação são removidos os suportes sob o tubo e o êmbolo superior. É posicionada uma tampa na parte superior do tubo e sobre ela a célula de carga. O tubo é empurrado para baixo pelo avanço da prensa, então medido pela célula de carga o esforço necessário para romper o atrito estático entre a areia compactada anteriormente e a parede interna do tubo. 


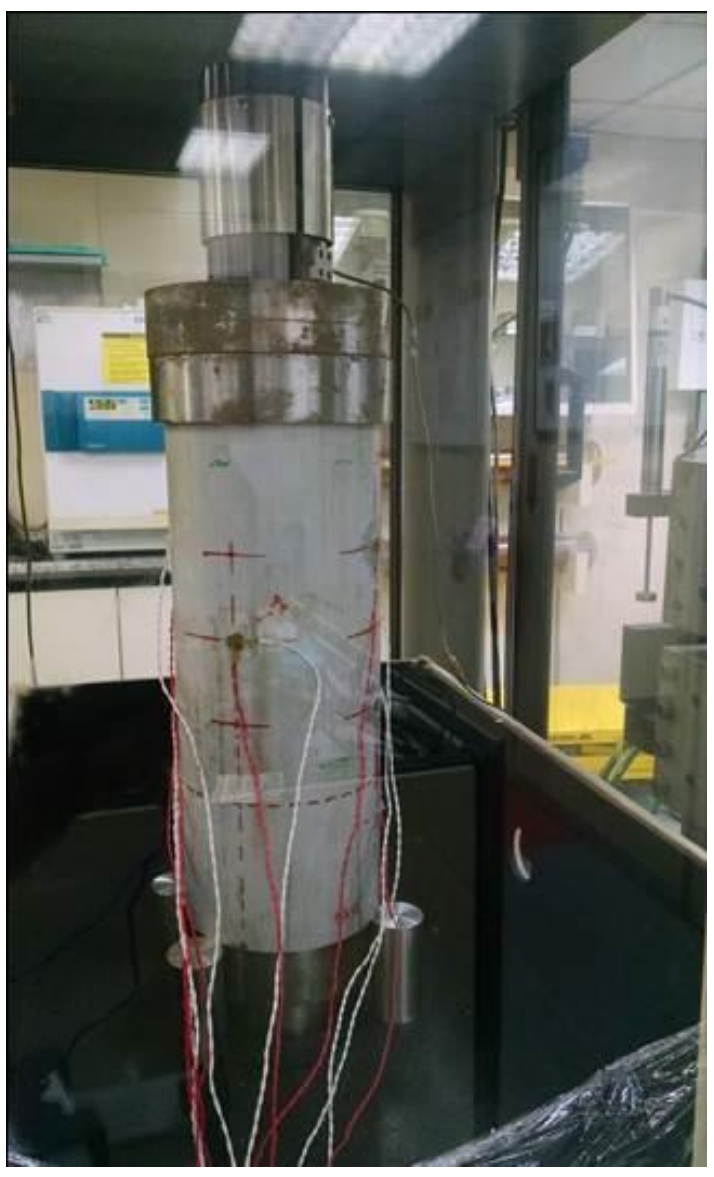

Figura 4.5: tubo de alumínio instrumentado para a fase de deslocamento relativo tubo-areia. Apesar de exibidos na foto, os plugues usados como suporte para o tubo são removidos antes do início da aplicação da carga.

\subsection{4.}

\section{Resultados}

De forma a maximizar a segurança do experimento, os ensaios foram iniciados com níveis menores de compactação. O primeiro e segundo ensaios foram realizados com uma força máxima de compactação de 20 e $50 \mathrm{kN}$. Entretanto, ao se remover o carregamento de compactação da areia os extensômetros circunferenciais mostravam uma leitura próxima de zero, sugerindo que não havia compactação residual ou era diminuta. Isso ainda tornava inviável a avaliação da força normal exercida pela areia sobre a superfície interna do tubo, já que tais leituras permaneciam dentro da faixa de incerteza dos strain gauges, que apresentavam uma oscilação gradativa de até cerca de $15 \mu \mathrm{m} / \mathrm{m}$ ao longo do ensaio. 
Ainda assim, a fase de translação de cada ensaio apresentou resultados coerentes para o esforço necessário para o deslocamento do tubo através da areia, embora com razoável incerteza devido à baixa magnitude dos esforços envolvidos.

Nesta fase, ao se considerar a carga total aplicada sobre o tubo, deve ser somada à carga exercida pela prensa a força peso provocada pela massa de quatro componentes posicionados sobre o tubo: duas tampas $(5,8$ e $5,9 \mathrm{~kg})$, a célula de carga $(3,97 \mathrm{~kg})$ e uma rótula $(4,05 \mathrm{~kg})$. Tanto a rótula quanto a segunda tampa foram adicionadas para adequar a altura do conjunto à amplitude do curso da prensa. Isso significa que quando a prensa inicia a aplicação da carga o tubo já encontra-se com sob uma carga de 193,25 N.

No ensaio com compactação de 20 kN (tensão de 1,38 MPa) observou-se a movimentação do tubo quando a prensa aplicou $370 \mathrm{~N}$, totalizando desta forma $563 \mathrm{~N}$ necessários para o tubo iniciar seu movimento.

Já o ensaio com compactação de $50 \mathrm{kN}$ (tensão de 3,44 MPa) apresentou o comportamento mostrado na Figura 4.6.

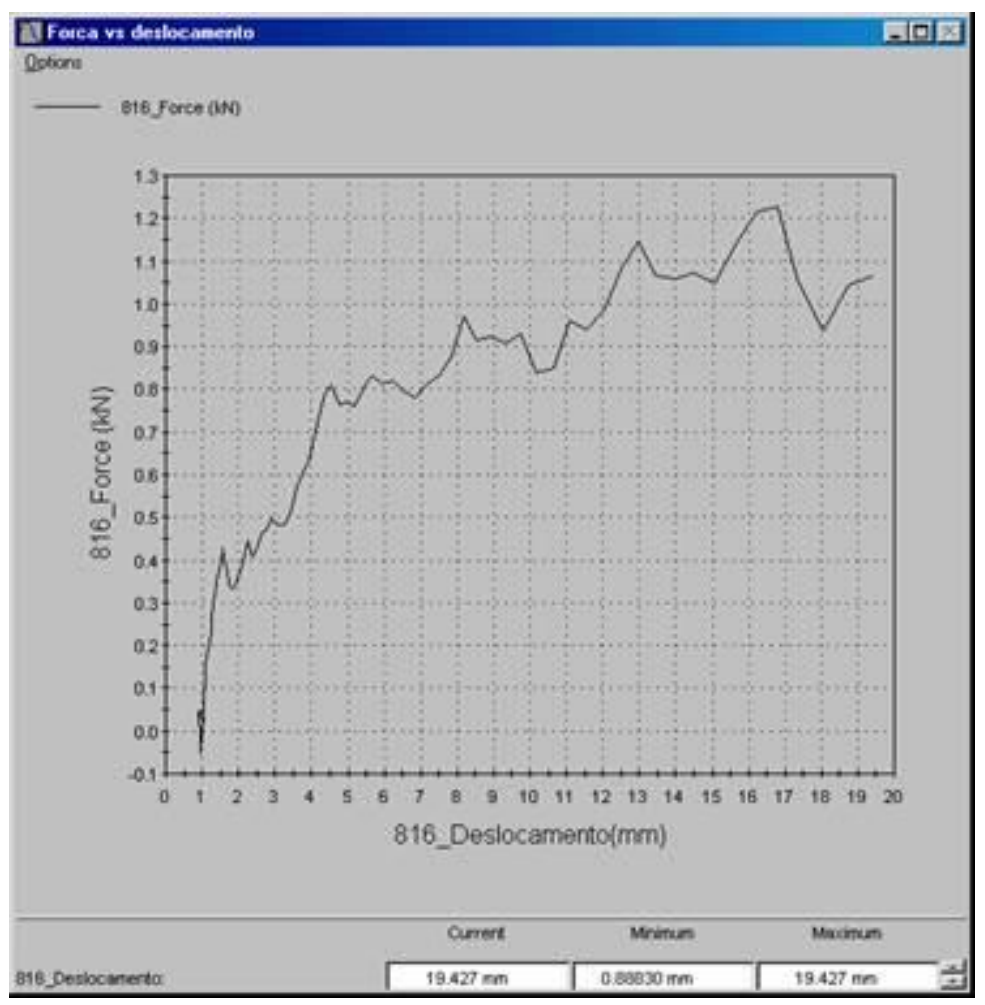

Figura 4.6: diagrama força $\mathrm{x}$ deslocamento para fase de translação do ensaio de areia compactada com $50 \mathrm{kN}$ 
Considerou-se como o momento quando se rompe o atrito estático o ponto máximo de $1200 \mathrm{~N}$ (cerca de $1400 \mathrm{~N}$ no total). O deslocamento anterior a esse ponto assume-se como um deslocamento para a acomodação, seja entre a superfície da prensa e a superfície da célula de carga, que no início do contato não apresentavam um perfeito paralelismo, ou entre a tampa e o tubo.

Na Figura 4.7 são consolidados os resultados para a carga limite para o escorregamento em função da força axial aplicada.

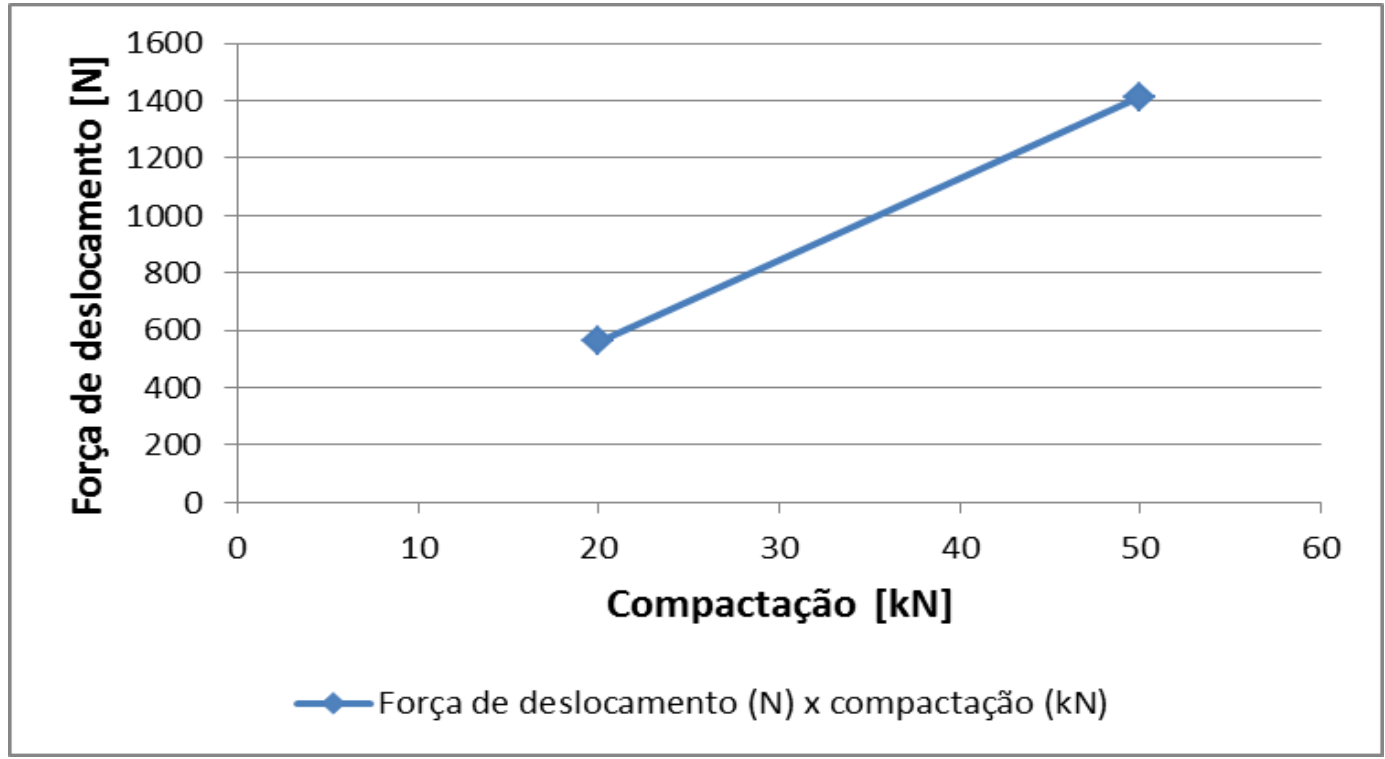

Figura 4.7: relação entre a força necessária para deslocar o tubo em função da carga usada para a compactação da areia

De qualquer forma pode-se notar na Figura 4.6 que, com tão reduzida compactação, é muito difícil definir com razoável exatidão o momento em que se rompe o atrito estático e tubo começa a se mover. Além disso, a medição de deformação circunferencial praticamente nula impede a avaliação da tensão normal, fundamental para que se determine o coeficiente de atrito. Sendo assim, suspeitava-se que para se obter resultados mais refinados e com uma exatidão adequada seria necessário realizar o ensaio com um maior grau de compactação da areia.

Um terceiro ensaio foi executado, desta vez com $80 \mathrm{kN}$ de compactação mas um incidente provocou o tombamento do espécime, e assim impediu a realização da fase de translação. O incidente desencorajou a realização de experimentos com níveis maiores de compactação. 
O experimento apresentou resultados decepcionantes na intenção original de determinar o coeficiente de atrito através da translação do tubo ao redor da coluna de areia compactada. Com isso, buscou-se uma maneira alternativa de atingir esse objetivo, analisando a distribuição de esforços na parede do tubo durante a fase de compactação e comparando com curvas obtidas para diferentes coeficientes de atrito em uma reprodução do experimento no computador através de simulações em Elementos Finitos.

\subsection{5.}

\section{Determinando os parâmetros da areia}

Os resultados obtidos durante a compactação da areia com $80 \mathrm{kN}$ de força aplicada pela prensa foram utilizados para a obtenção dos parâmetros elásticos da areia (ver Anexo 1), como módulo de Young (E) e coeficiente de Poisson $(\mu)$. Tais parâmetros são fundamentais para a correta avaliação do experimento e inclusive foram utilizados na simulação em EF descrita no próximo capítulo.

A Figura 4.8 mostra a força aplicada sobre a areia em função do deslocamento da prensa. O valor absoluto do deslocamento não deve ser considerado tão relevante, já que existia uma certa dificuldade em definir o momento exato em que a prensa efetivamente estabelecia contato com a célula de carga pra um exato ajuste do deslocamento zero.

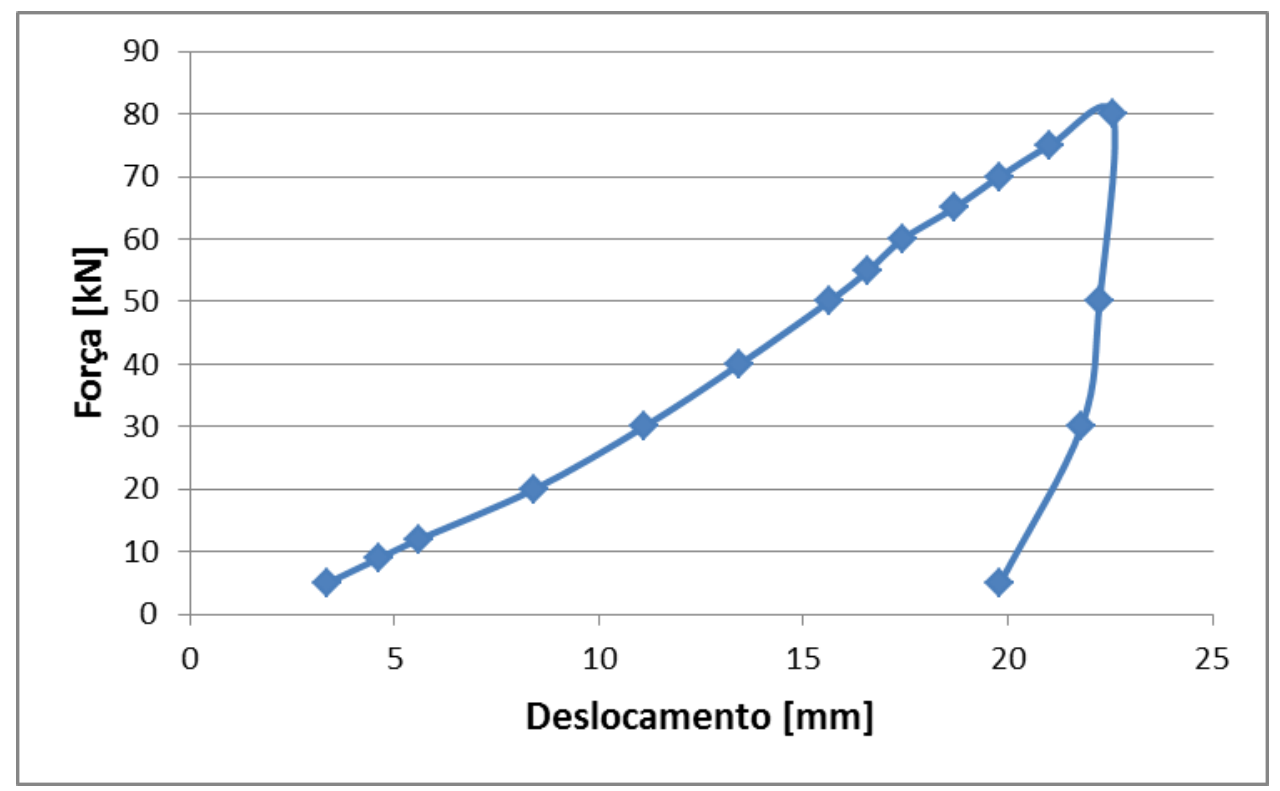

Figura 4.8: Relação entre a carga aplicada e o curso da prensa nas trajetórias de carregamento e descarregamento 
$\mathrm{Na}$ trajetória cabe ressaltar, primeiramente, a não linearidade no início, devido à acomodação da prensa, êmbolo e também do rearranjo dos próprios grãos da areia. A concavidade para cima, principalmente no trecho inicial, mostra o enrijecimento gradativo da areia produzido pela compactação. Outro ponto a se observar é a trajetória diferente no descarregamento, indicando a plastificação provocada pela compactação da amostra, findando em um rebaixamento do topo da areia em quase $20 \mathrm{~mm}$, semelhante ao valor de aproximadamente $17 \mathrm{~mm}$ medido com uma trena após a remoção do êmbolo (Figura 4.9). Ao término do ensaio a distância entre o topo da coluna de areia e o topo do tubo era de $57 \mathrm{~mm}$, $17 \mathrm{~mm}$ além dos $40 \mathrm{~mm}$ antes da compactação.

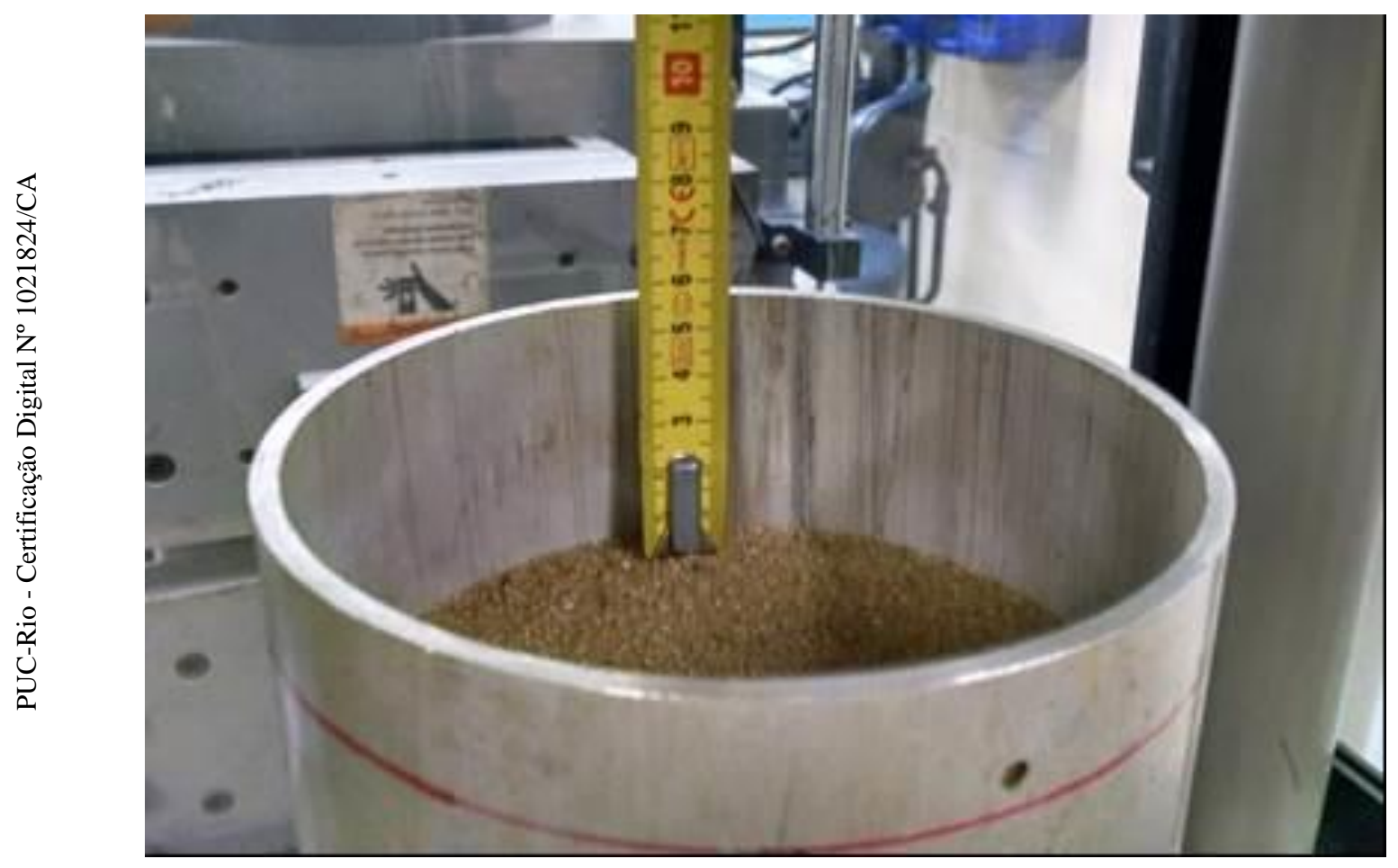

Figura 4.9: topo do tubo de alumínio, mostrando a areia compactada após o teste com compressão de $80 \mathrm{kN}$ de força axial

Durante ensaio com carregamento de $50 \mathrm{kN}$ um segundo ciclo de carregamento e descarregamento foi realizado após cerca de 120 minutos de repouso. Na trajetória podemos perceber novamente a componente de deformação plástica da areia, além da trajetória mais "íngreme" durante o carregamento na areia já préviamente consolidada. O valor absoluto do deslocamento da prensa neste segundo ciclo não deve ser comparado criteriosamente com o primeiro, já 
que parte do aparato foi desmontado e remontado após o primeiro carregamento. A remoção e reposicionamento do êmbolo superior sempre altera a referência de deslocamento.

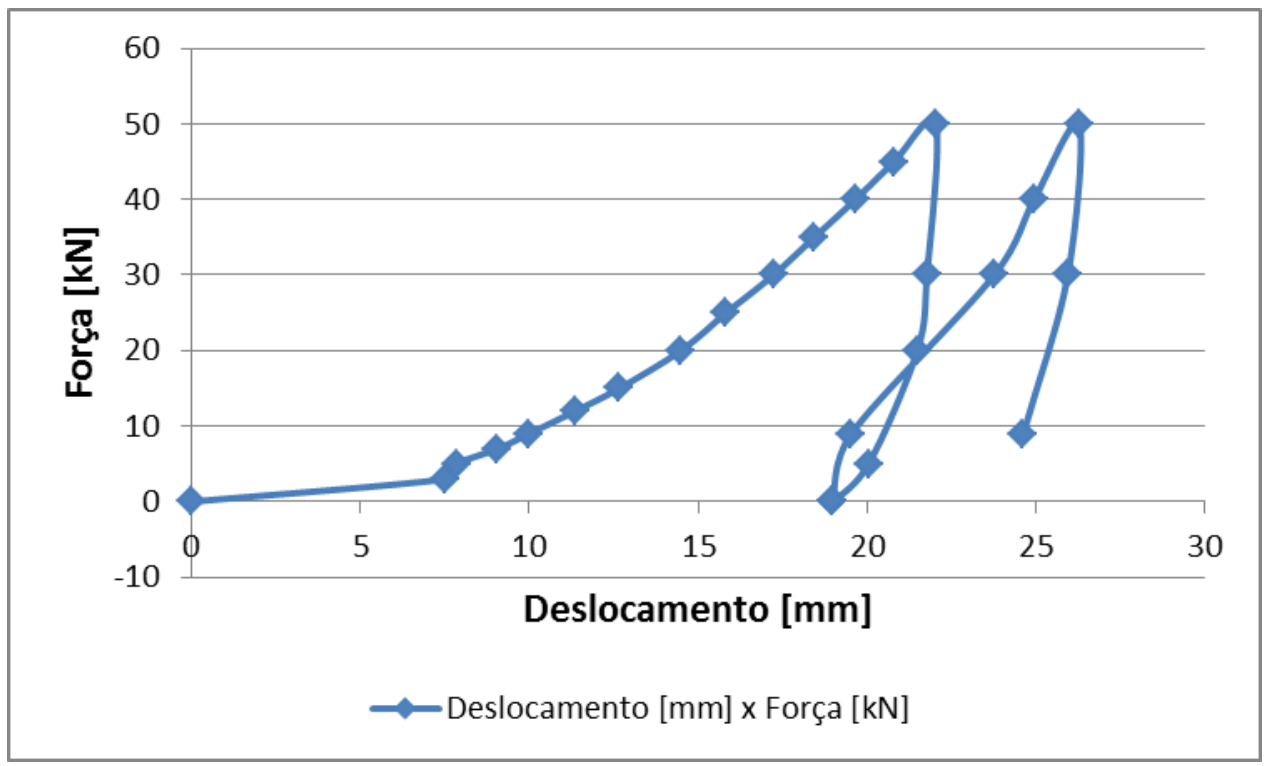

Figura 4.10: No ensaio com carregamento de $50 \mathrm{kN}$ um segundo ciclo foi realizado após $120 \mathrm{~min}$ de repouso

Conforme mencionado no capítulo 2, na dificuldade de se executarem inúmeros ciclos, o descarregamento é a melhor fase para se determinar os parâmetros elásticos da areia.

Nos experimentos desse trabalho, por simplicidade, por se tratar de areia seca, a componente de deformação dependente do tempo não será considerada, nem mensurada.

$$
\mathrm{d} \varepsilon=\mathrm{d} \varepsilon^{\text {elast }}+\mathrm{d} \varepsilon^{\text {plast }}+\mathrm{d} \varepsilon^{\mathrm{er}}
$$

Em síntese, a determinação das componentes de deformação elástica e plástica são determinadas conforme a Figura, onde a deformação total $\left(\varepsilon_{t}\right)$ é determinada no carregamento primário e a deformação elástica ( $\varepsilon_{\text {elast}}$ ) no descarregamento, sendo então a deformação plástica $\left(\varepsilon_{\text {plast }}\right)$ a diferença entre as duas. 


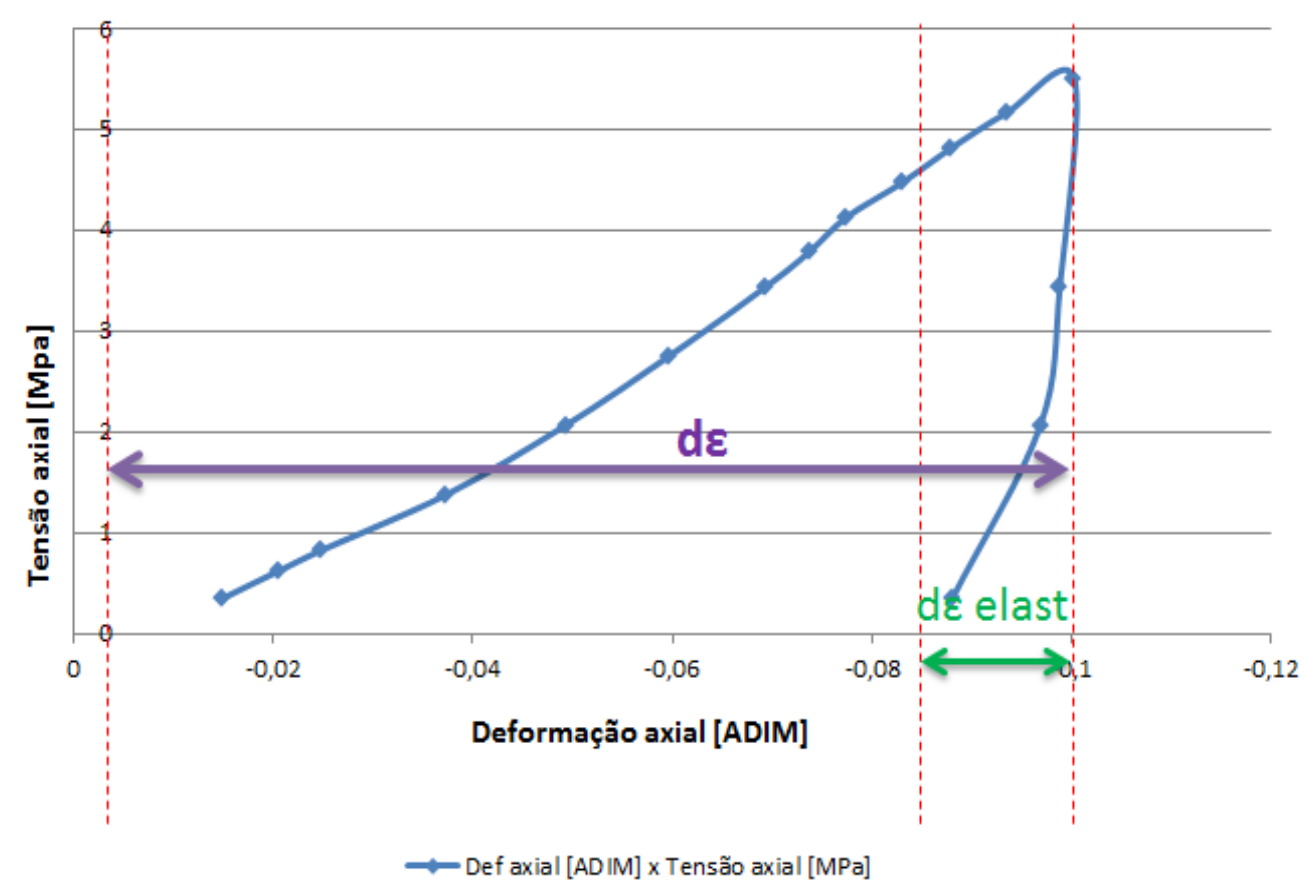

Figura 4.11: componente de deformação elástica determinada na trajetória de descarregamento

É possível notar, a partir dos dados da tabela da fase de compactação da areia (Anexo 1), que o elevado módulo de elasticidade da liga de alumínio do tubo faz com que a deformação circunferencial deste, e consequentemente a deformação lateral da coluna de areia seja substancialmente menor que a deformação axial da própria areia. Isso permite que se aproxime a fase de compactação a um ensaio edométrico, onde a deformação lateral da amostra ( $\left.\varepsilon_{3}\right)$ é restringida.

Dedicando uma atenção aos quatro últimos pontos dos resultados, a relação entre $\sigma_{3}$ e $\sigma_{1}$ tende a se estabilizar em torno de 0,5 . Relembrando a eq. (2.25):

$$
\frac{\sigma_{3}}{\sigma_{1}}=\left(\frac{v}{1-v}\right)=0,5
$$

Desta forma conclui-se que a areia utilizada no ensaio possui um coeficiente de Poisson ( $v$ ) de aproximadamente 0,334, pelo menos para a faixa de compactação em questão. 
A partir das equações 2.26, obtem-se ainda:

$$
\begin{aligned}
& E_{\text {oed }}^{u r}=\frac{516,55}{0,01222}=42263,32 \quad\left[\mathrm{~N} / \mathrm{cm}^{2}\right] \\
& \mathrm{E}_{\text {oed }}^{\text {ur }}=422,633 \mathrm{MPa} \\
& v=0,334 \\
& \mathrm{E}_{\text {ur }}=0,66 . \mathrm{E}_{\text {oed }}{ }^{\text {ur }}
\end{aligned}
$$

Então:

$$
\mathrm{E}_{\mathrm{ur}}=278,97 \mathrm{MPa}
$$

É importante lembrar que este módulo de rigidez $\left(\mathrm{E}_{\mathrm{ur}}\right)$ se refere às fases de descarregamento e recarregamento, quando prevalece a componente elástica de deformação. Portanto não deve ser confundido com a compressibilidade da areia em seu carregamento primário.

Optando-se por uma modelagem mais simples para a etapa de carregamento pode-se considerar a trajetória de compactação da areia como um modelo elástico equivalente. De qualquer forma, para se determinar o módulo de elasticidade de tal modelo ( $\left.E_{\text {elast }}\right)$ recomenda-se desconsiderar o início da trajetória, de modo a evitar a influência de erros provocados pela acomodação da prensa, do êmbolo e da própria areia. Valendo-se novamente da Lei de Hooke, e aproveitando os dados experimentais do Anexo 1 entre os pontos de 40 e $80 \mathrm{kN}$, estimou-se o seguinte valor para o módulo de elasticidade:

$$
\mathrm{E}_{\text {elast }}=36,15 \mathrm{MPa}
$$

$\mathrm{Na}$ intenção de se dispor de um modelo mais fiel, convém retratar o comportamento elastoplástico da areia. Nesse caso, a componente elástica de deformação foi determinada nas trajetórias de descarregamento. Já a componente plástica foi determinada como o complemento para a deformação total, obtida no 
carregamento primário. A propagação da compactação plástica provê um comportamento elasto-plástico progressivo. Um endurecimento isotrópico (hardening) do material, onde sua resistência depende do carregamento hidrostático.

Analisando a trajetória de tensões no diagrama de Lambe [6] durante o carregamento primário, esta determina a linha $\mathrm{K}_{0}$.

Para modelar a componente plástica construiu-se uma tabela para o endurecimento que representa a progressão da deformação plástica. Tal tabela define a relação entre a deformação volumétrica plástica e a tensão média (p). Para tanto, foram utilizados os dados de deformação plástica da areia para os diferentes valores de carregamento.

\begin{tabular}{|l|l|l|}
\hline Ensaio (Força) & $\mathbf{p}(\mathbf{P a})$ & $\mathbf{\varepsilon}^{\text {plast }}$ [ADIM] \\
\hline $\mathbf{5 0} \mathbf{~ k N}$ & 2589408 & 0,0577 \\
\hline $\mathbf{8 0} \mathbf{~ k N}$ & 4150436 & 0,07316 \\
\hline
\end{tabular}

Tabela 2: Dados de deformação plástica para estabelecer os parâmetros de endurecimento

Obteve-se a deformação plástica subtraindo-se a deformação elástica obtida no descarregamento da deformação total obtida no carregamento primário.

A tensão média foi obtida a partir dos valores de $\sigma_{1}$ e $\sigma_{3}$ mostrados na tabela do Anexo 1. 


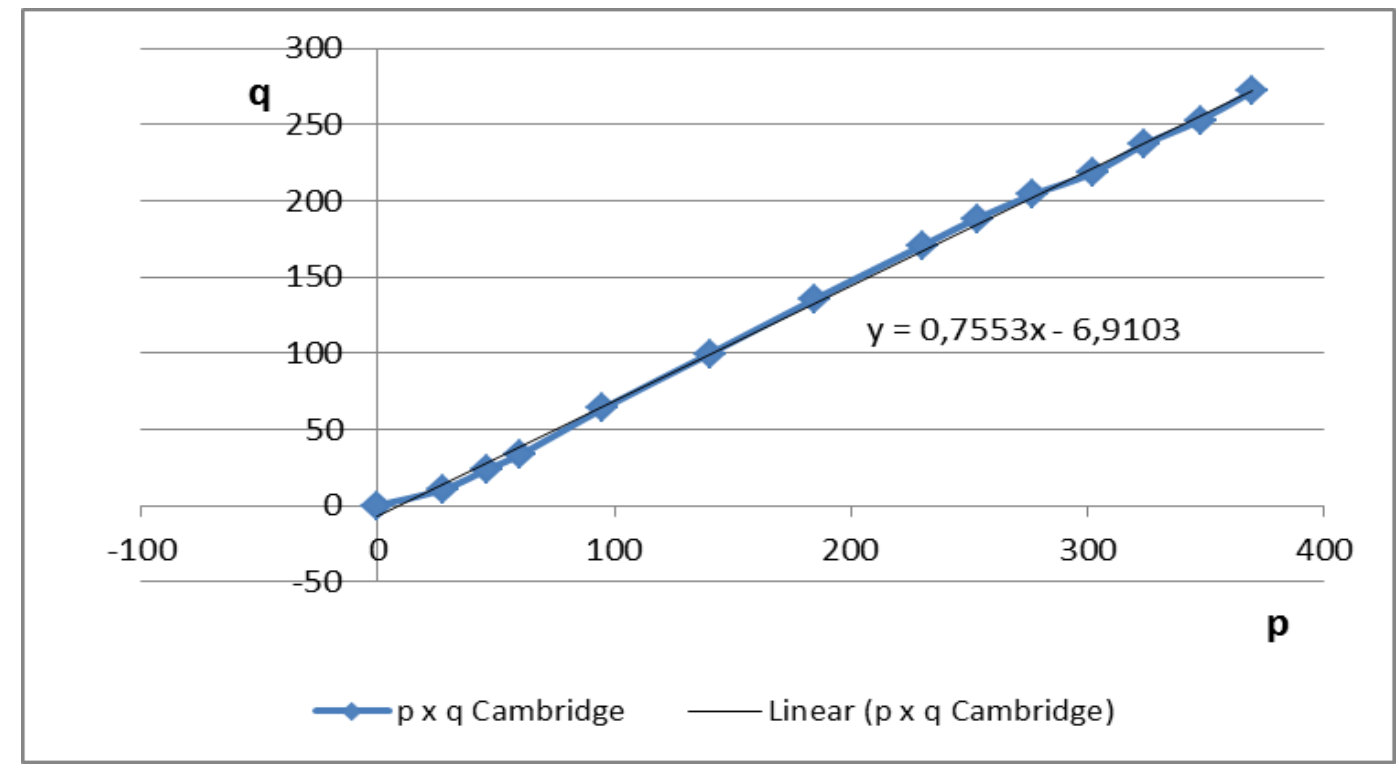

Figura 4.12: trajetória de carregamento no diagrama de Cambridge

$$
\beta=\arctan 0,7553=37,06^{\circ}
$$

Tais valores de endurecimento serão utilizados mais adiante na modelagem por elementos finitos como parâmetros de entrada para o modelo plástico da areia utilizando o critério de Drucker-Prager com cap.

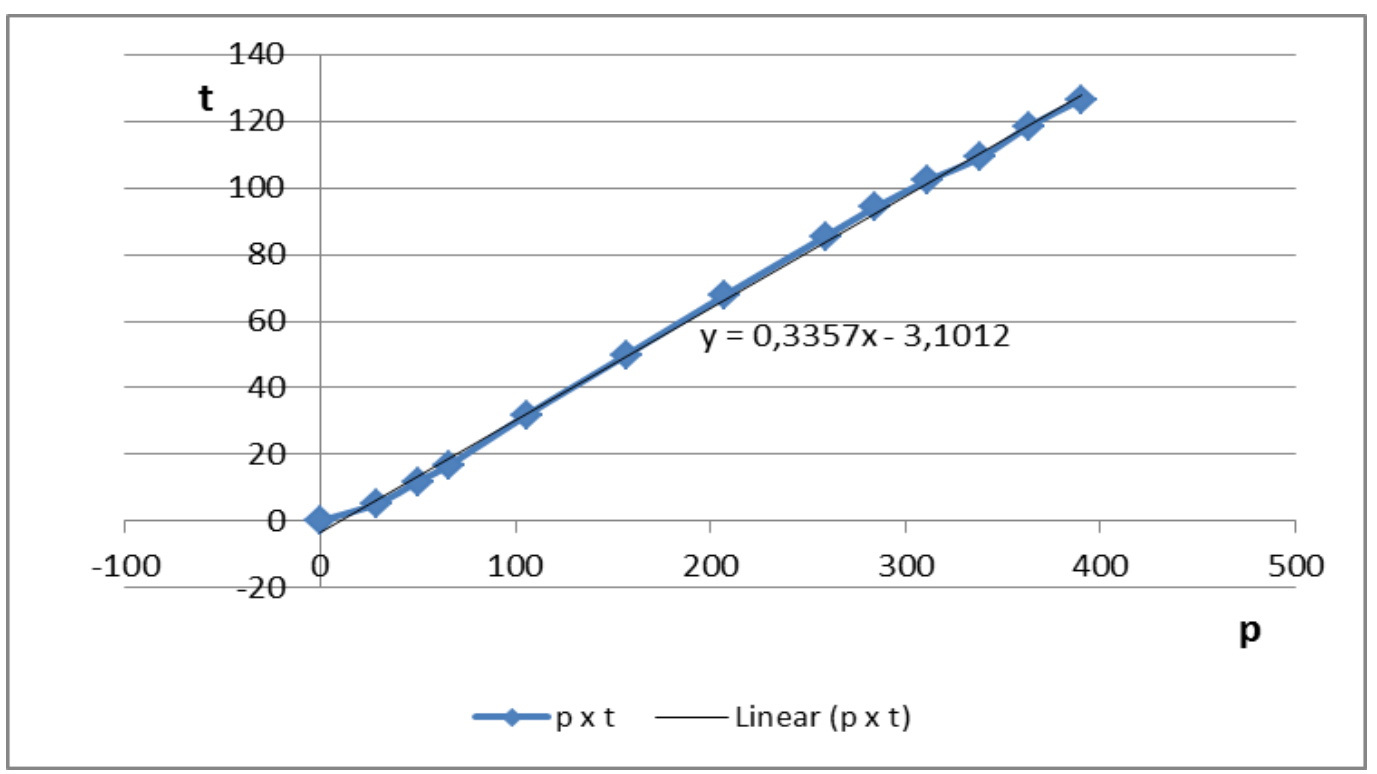

Figura 4.13: trajetória de carregamento no diagrama de Lambe 
De acordo com Lambe [6], a inclinação da linha $\mathrm{K}_{0}$ permite obter o ângulo de atrito interno através da seguinte relação:

$$
\tan \beta=\frac{\operatorname{sen} \phi}{2-\operatorname{sen} \phi}
$$

Desta forma:

$$
\begin{aligned}
& 0,3357=\frac{\operatorname{sen} \phi}{2-\operatorname{sen} \phi} \\
& \varnothing=30,15^{\circ}
\end{aligned}
$$

Obteve-se ainda o módulo volumétrico, Bulk Modulus (K), através da relação entre a tensão média $(\mathrm{p})$ e a deformação volumétrica $(\Delta \mathrm{V} / \mathrm{V})$.

$$
K=\frac{2862898}{0,099325}=28,82 \mathrm{MPa}
$$

Consolidando então as características da areia:

- Porosidade inicial $(\Phi)$ : 0,395;

- Massa específica $(\rho): 1,572 \mathrm{~g} / \mathrm{cm}^{3}$;

- Módulo de Young considerando um meio elástico equivalente: 36,15 MPa; Esse dado é em areia já compactada, diferente dos dois anteriores

- Módulo de Young da fase elástica, descarregamento ou recarregamento $\left(\mathrm{E}_{\mathrm{ur}}\right): 278,97 \mathrm{MPa}$;

- Coeficiente de Poisson (v): 0,334;

- Ângulo de atrito $(\varnothing): 30,15^{\circ}$;

- Módulo volumétrico (K): 28,82 MPa. 


\section{2.}

Resultados do experimento do plano inclinado

Seguindo o que foi proposto no item 3.2.2 foi realizado o experimento do plano inclinado que avaliou a inclinação necessária para o deslizamento de uma amostra de arenito no tubo de alumínio. $\mathrm{O}$ experimento foi repetido com a superfície seca e com a aplicação de diferentes fluidos de perfuração. Foram utilizados dois fluidos de base aquosa: o fluido convencional SCOL e o FPA Polimérico com adição de Goma Xantana para incremento da viscosidade. Como fluido de base sintética foi utilizada amostra do fluido com base de olefinas (Oledrill), que hoje em dia substitui os fluidos com base parafínica por ser mais biodegradável.Os resultados estão dispostos na tabela 3:

\begin{tabular}{|c|c|c|c|c|}
\hline $\mathbf{n}$ & $\begin{array}{l}\text { Superfície } \\
\text { seca }\end{array}$ & SCOL & $\begin{array}{c}\text { FPA } \\
\text { Polimérico com } \\
\text { Goma Xantana }\end{array}$ & Oledrill \\
\hline 1 & 29,5 & 17 & 24 & 21 \\
\hline 2 & 30,5 & 21 & 20,5 & 18 \\
\hline 3 & 33 & 19 & 24 & 21 \\
\hline 4 & 28 & 21 & 25,5 & 16 \\
\hline 5 & 27 & 28 & 19,5 & 14 \\
\hline 6 & 29,5 & 25 & 24 & 14 \\
\hline 7 & 30,5 & 27 & 19 & 21 \\
\hline 8 & 29 & 17 & 19,5 & 17 \\
\hline 9 & 29 & 26 & 19,5 & 21,5 \\
\hline 10 & 30,5 & 24 & 26 & 22 \\
\hline 11 & 28 & 22 & 18 & 18 \\
\hline 12 & 33 & 20,5 & 22 & 18 \\
\hline $\begin{array}{l}\text { Inclinação } \\
\text { média }\left(^{0}\right)\end{array}$ & 29,79 & 22,29 & 21,79 & 18,46 \\
\hline $\begin{array}{c}\text { Coeficiente } \\
(\mu)\end{array}$ & 0,572 & 0,410 & 0,400 & 0,334 \\
\hline
\end{tabular}

Tabela 3: Resultados dos experimentos do plano inclinado em termos de inclinação máxima para atrito estático 
O coeficiente de atrito $(\mu)$ foi determinado a partir da inclinação do tubo, utilizando as relações explicadas anteriormente no sub-capítulo 2.1.2.

Apesar de uma razoável dispersão, os resultados mostraram claramente a influência dos diferentes fluidos de perfuração na redução do coeficiente de atrito em relação ao coeficiente da superfície seca de 0,572. Os fluidos de base aquosa apresentaram resultados muito próximos (em torno de 0,400). Já o fluido de base sintética, como era de se esperar, apresentou drástica redução no coeficiente, atingindo o valor de 0,334 . 


\section{5 \\ Modelagem em Elementos Finitos}

5.1.

Modelagem da compactação da areia no interior do tubo

O insucesso em determinar o coeficiente de atrito na segunda fase do ensaio (translação) fez com que a reprodução do ensaio através do MEF se tornasse mais importante, como um recurso para se inferir o coeficiente de atrito comparando a deformação medida na parede do tubo durante a compactação aos resultados das simulações parametrizadas para diferentes coeficientes de atrito.

Utilizou-se então o Abaqus para reproduzir a primeira fase do experimento, a compactação da areia no interior do tubo de alumínio.

\subsection{1.}

\section{Geometria de análise}

Para tanto se construiu um modelo axisimétrico simples contendo três elementos principais: o tubo, a areia e o êmbolo superior. Não se julgou necessário o modelo do êmbolo inferior. Em substituição se adicionou uma condição de contorno restringindo o movimento da base da areia na direção vertical (Y).

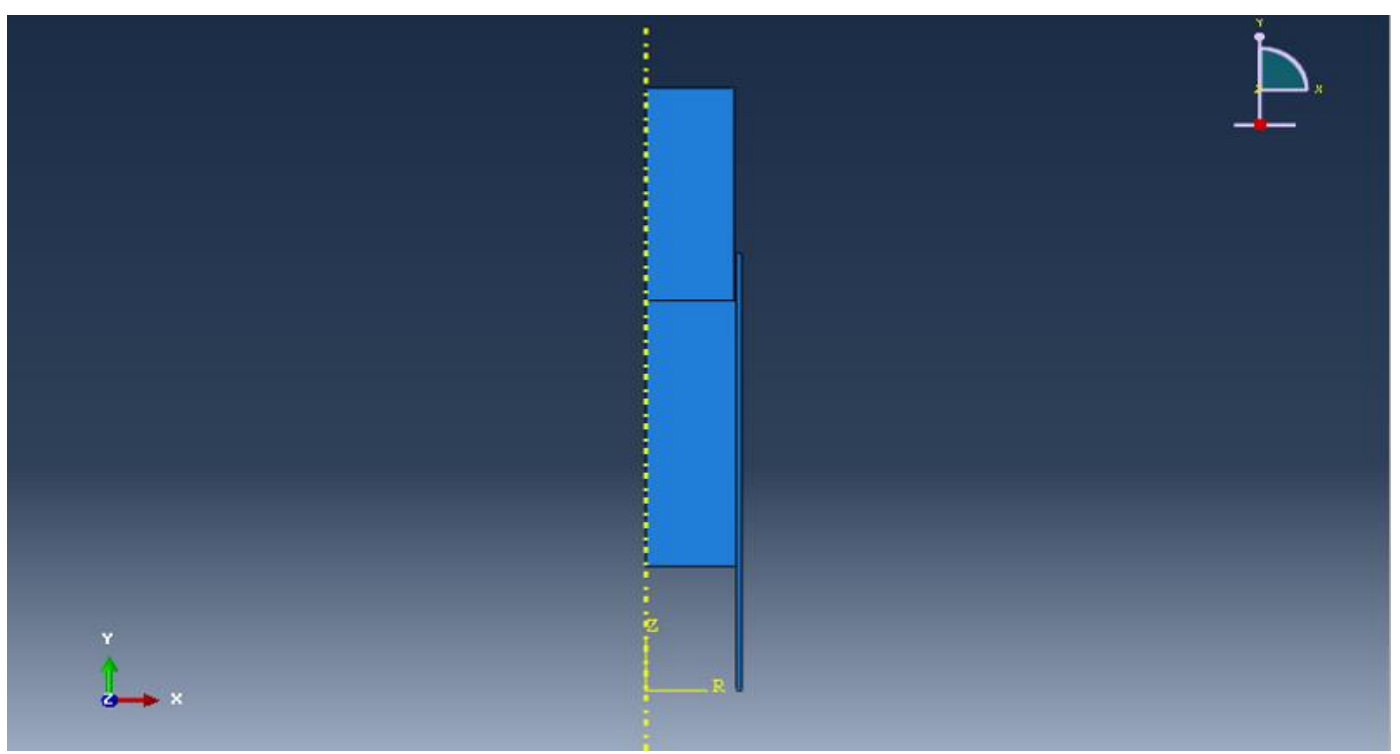

Figura 5.1: Modelo axissimétrico contendo o tubo, a areia e o êmbolo superior 
As dimensões e posicionamento seguem as do ensaio, definidas no Capítulo 3.2.1.

\begin{tabular}{|c|c|c|c|c|c|}
\hline \multicolumn{2}{|c|}{ Tubo } & \multicolumn{2}{|c|}{ Cilindro de areia } & \multicolumn{2}{|c|}{ Êmbolo } \\
\hline $\begin{array}{l}\text { Raio } \\
\text { interno } \\
(\mathrm{cm})\end{array}$ & 6,85 & $\begin{array}{c}\text { Raio } \\
\text { externo } \\
(\mathrm{cm})\end{array}$ & 6,85 & $\begin{array}{c}\text { Raio } \\
\text { externo } \\
(\mathrm{cm})\end{array}$ & 6,6675 \\
\hline $\begin{array}{l}\text { Raio } \\
\text { externo } \\
(\mathrm{cm})\end{array}$ & 7,24 & Altura $(\mathrm{cm})$ & & Altura $(\mathrm{cm})$ & 18 \\
\hline $\begin{array}{l}\text { Altura } \\
(\mathrm{cm})\end{array}$ & 37 & Topo & $\begin{array}{c}4 \mathrm{~cm} \\
\text { abaixo do } \\
\text { topo do } \\
\text { tubo de } \\
\text { alumínio }\end{array}$ & & \\
\hline
\end{tabular}

Tabela 4: Dimensões adotadas na simulação

\subsection{2.}

Materiais

Foram incorporados ao modelo os parâmetros de três materiais: 1. a liga de alumínio que compõe o tubo utilizado na testemunhagem; 2. O aço utilizado na fabricação do êmbolo; 3. a areia utilizada no ensaio.

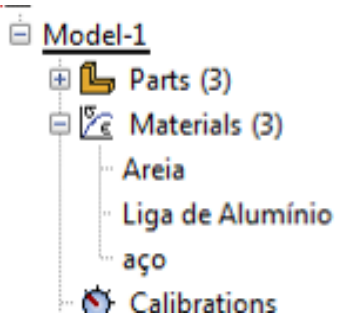

Figura 5.2: Materiais incorporados ao modelo

Enquanto as duas ligas metálicas tiveram suas características obtidas de catálogo, a areia teve suas características determinadas no laboratório e seu comportamento elasto-plástico determinados a partir dos dados do próprio ensaio 
de compactação valendo-se de considerações descritas anteriormente no subcapítulo 4.1.5.

As simulações iniciais foram realizadas tentando aplicar um modelo elástico equivalente, entretanto o desvio entre os resultados iniciais da simulação em relação ao experimento motivaram a incorporação da plasticidade da areia ao modelo. Para a representação de um material com tais características dentre as opções oferecidas pelo Abaqus foi escolhido o modelo de Drucker-Prager modificado com Cap e endurecimento (ver item 2.11.2).

\section{Liga de alumínio}

Densidade: 2,7

Comportamento elástico isotrópico:

Módulo de Young (E): 70 GPa;

Coeficiente de Poisson (v): 0,33.

\section{Liga de aço}

Densidade: 7,85

Comportamento elástico isotrópico:

Módulo de Young (E): 200 GPa;

Coeficiente de Poisson (v): 0,3.

\section{Areia}

Densidade: 1,572

Comportamento elástico isotrópico:

Módulo de Young (E): 36,15 MPa;

Coeficiente de Poisson (v): 0,334.

Plasticidade representada através do critério de Drucker-Prager:

Inclinação da envoltória no diagrama p x q de Cambridge ( $\beta$ ): 37,06.

Ângulo de dilatância: $0^{\circ}$.

O ângulo de dilatância será irrelevante nesse caso já que a envoltória de cisalhamento não será ultrapassada, e sim a do cap. 


\subsection{3.}

\section{Condições de contorno}

- Base da areia não se movimenta na direção Y (U2=0);

- Base do tubo não se movimenta na direção Y e não apresenta movimento rotacional em torno dos eixos $\mathrm{X}$ e $\mathrm{Z}$ (U2=0; $\mathrm{UR} 1=\mathrm{UR} 3=0$ ).

\subsection{4.}

\section{Carregamento}

Para a simulação do ensaio com força de $80 \mathrm{kN}$ foi criada a atuação de uma pressão no topo do êmbolo superior de $5,73 \mathrm{MPa}$, equivalente à distribuição da força de $80 \mathrm{kN}$ aplicada pela prensa sobre a área da seção transversal do êmbolo $\left(0,013966 \mathrm{~m}^{2}\right)$.

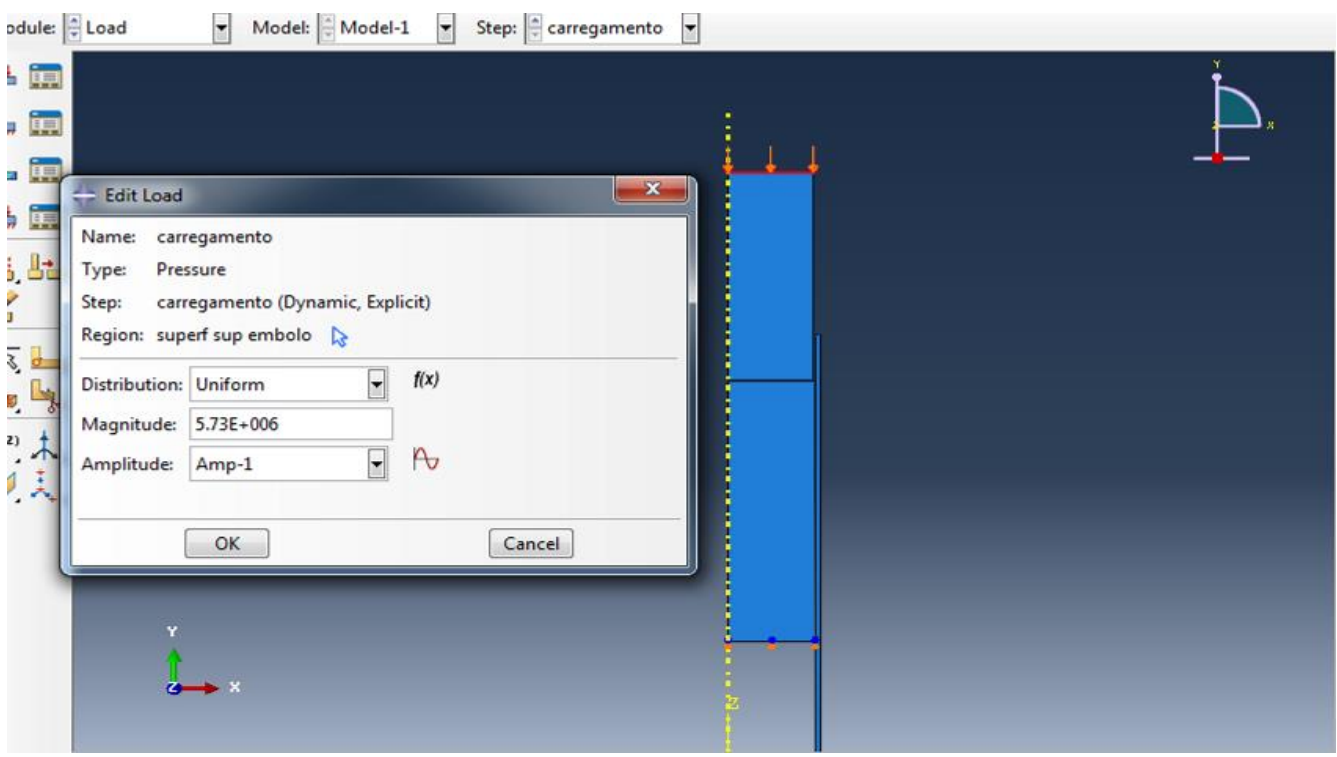

Figura 5.3: Aplicação do carregamento e condições de contorno 


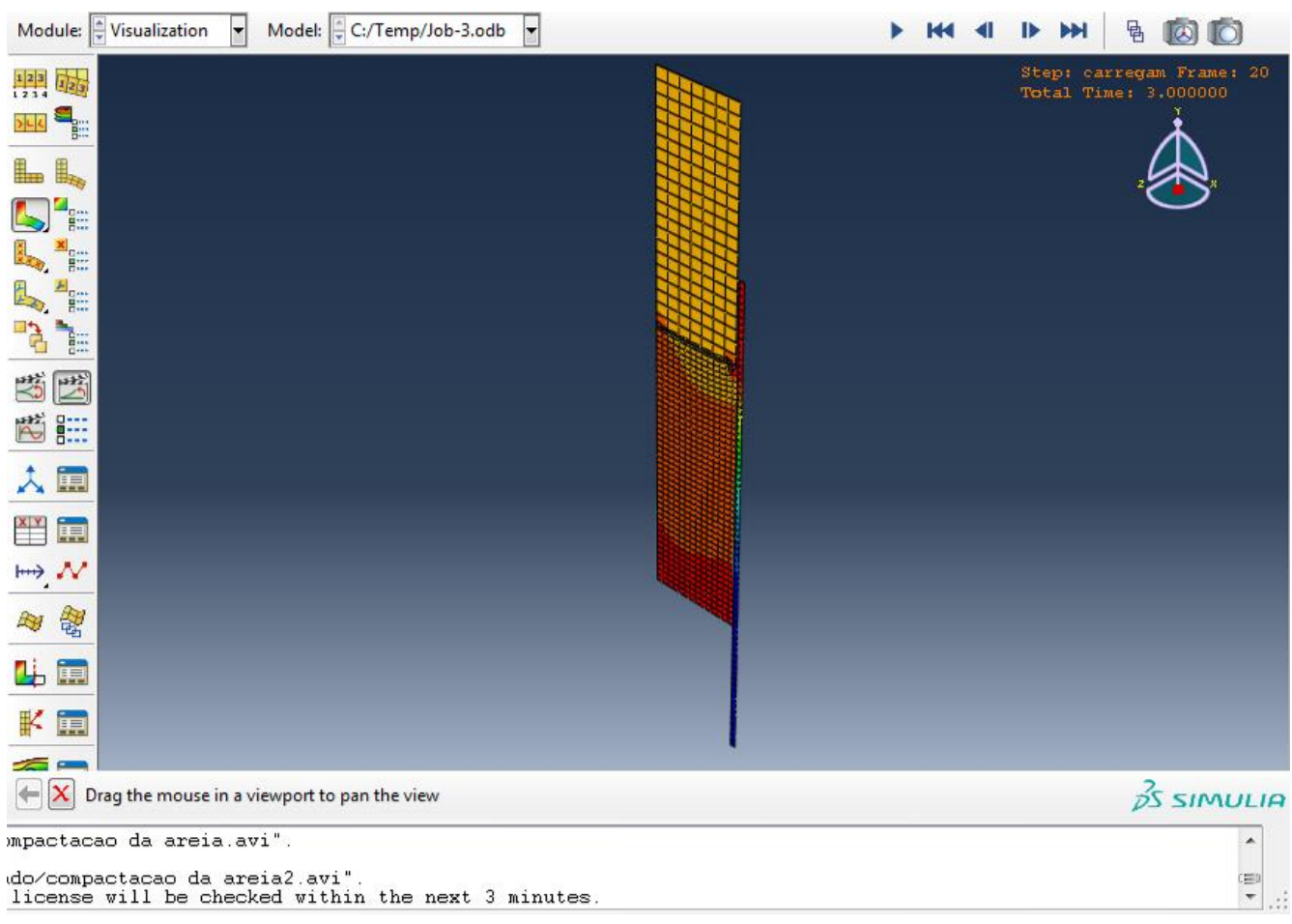

Figura 5.4: Êmbolo aplicando carregamento sobre a coluna de areia

Optou-se pela formulação explícita (Abaqus Explicit) pela expectativa de trabalhar melhor com interações entre superfícies. Além disso, tentativas de utilizar o Abaqus Standard no mesmo modelo resultavam em erro relacionado a um deslocamento excessivo entre as malhas de cada superfície.

De modo a evitar os efeitos inerciais de um carregamento abrupto foi necessário adicionar um controle suavizador (smooth amplitude) para sua aplicação.

\subsection{5.}

\section{Malha de elementos finitos}

Estabelecer a melhor resolução para a malha se resume em encontrar o equilíbrio entre uma resolução nem tão alta que torne exagerado o processamento, levando a simulações extremamente demoradas, e nem tão baixa que leve a resultados imprecisos, ou a um processamento instável devido à alta distorção dos elementos. Ao longo das simulações a resolução das malhas foi reduzida ou ampliada de acordo com as necessidades. Como exemplo, a malha da areia teve que ser refinada quando se reduziu o módulo de Young desse material pois a 
simulação tornou-se inviável devido à distorção excessiva de determinado(s) elemento(s) que compunham a malha.

Segue abaixo resumo da malha aplicada a cada elemento:

- Tubo: 74 elementos; CAX4R: 4-node bilinear axisymmetric quadrilateral, integração reduzida, hourglass control.

- Coluna de areia: CAX4R: 630 elementos (14 x 45); 4-node bilinear axisymmetric quadrilateral, integração reduzida, hourglass control.

- Êmbolo: 140 elementos (7 x 20); CAX4R: A 4-node bilinear axisymmetric quadrilateral, integração reduzida, hourglass control.

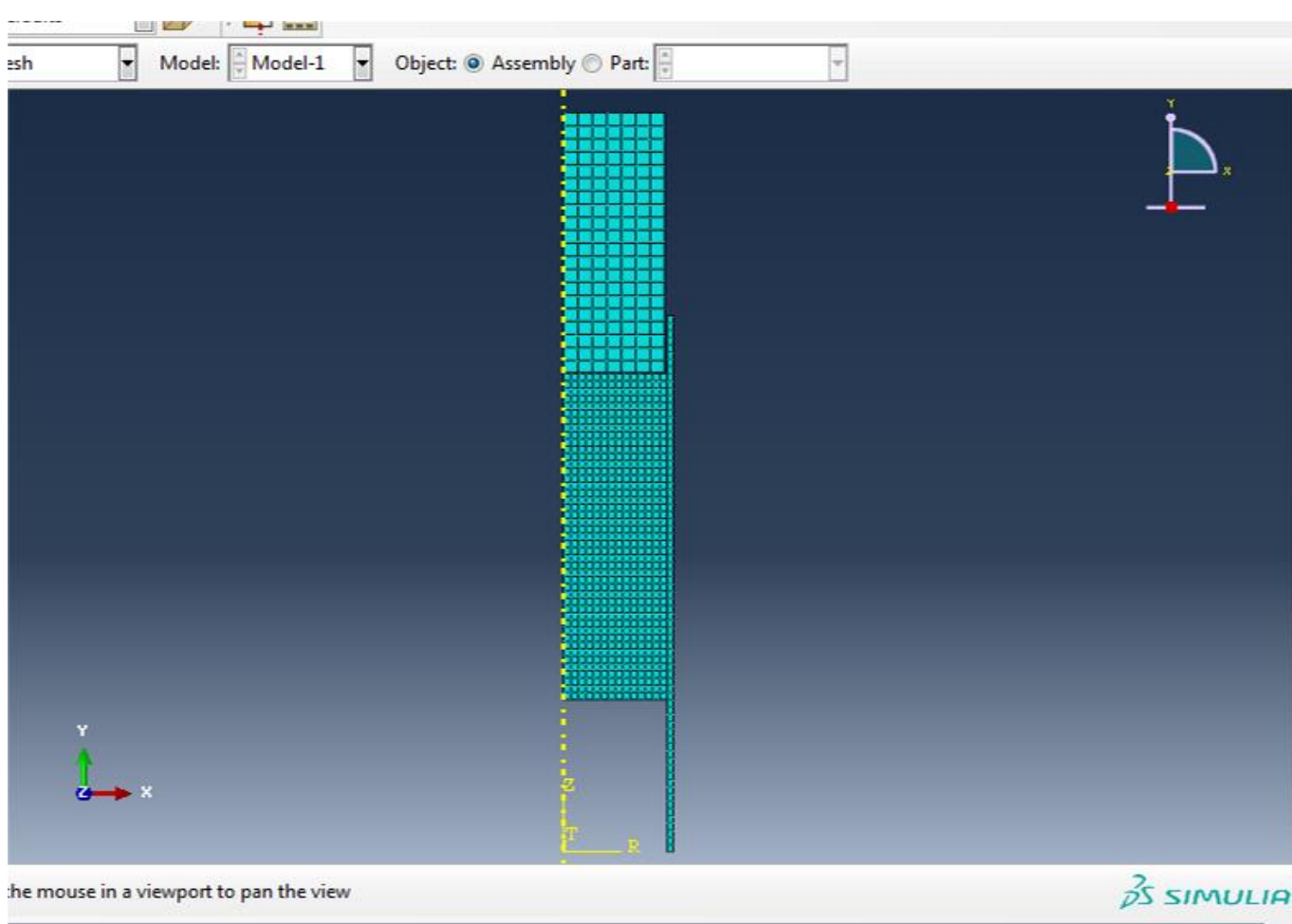

Figura 5.5: Malhas aplicadas aos componentes do modelo 


\subsection{6.}

\section{Resultados obtidos}

Conforme explicado anteriormente, a intenção de reproduzir através de simulação a fase de compactação da areia no interior do tubo era obter através dos dados experimentais uma estimativa para o coeficiente de atrito, já que a segunda fase do ensaio (translação), destinada a esse fim, não apresentou resultados conclusivos.

Desta forma foram efetuadas diversas simulações utilizando diferentes coeficientes de atrito para o contato entre a areia e o tubo. A idéia consistia em traçar curvas de distribuição da deformação circunferencial e axial ao longo da parede do tubo e verificar em qual curva melhor se encaixavam os dados experimentais.

Inicialmente as simulações foram realizadas aplicando à areia um modelo puramente elástico.

Os resultados dessas simulações são mostrados nas figuras a seguir:

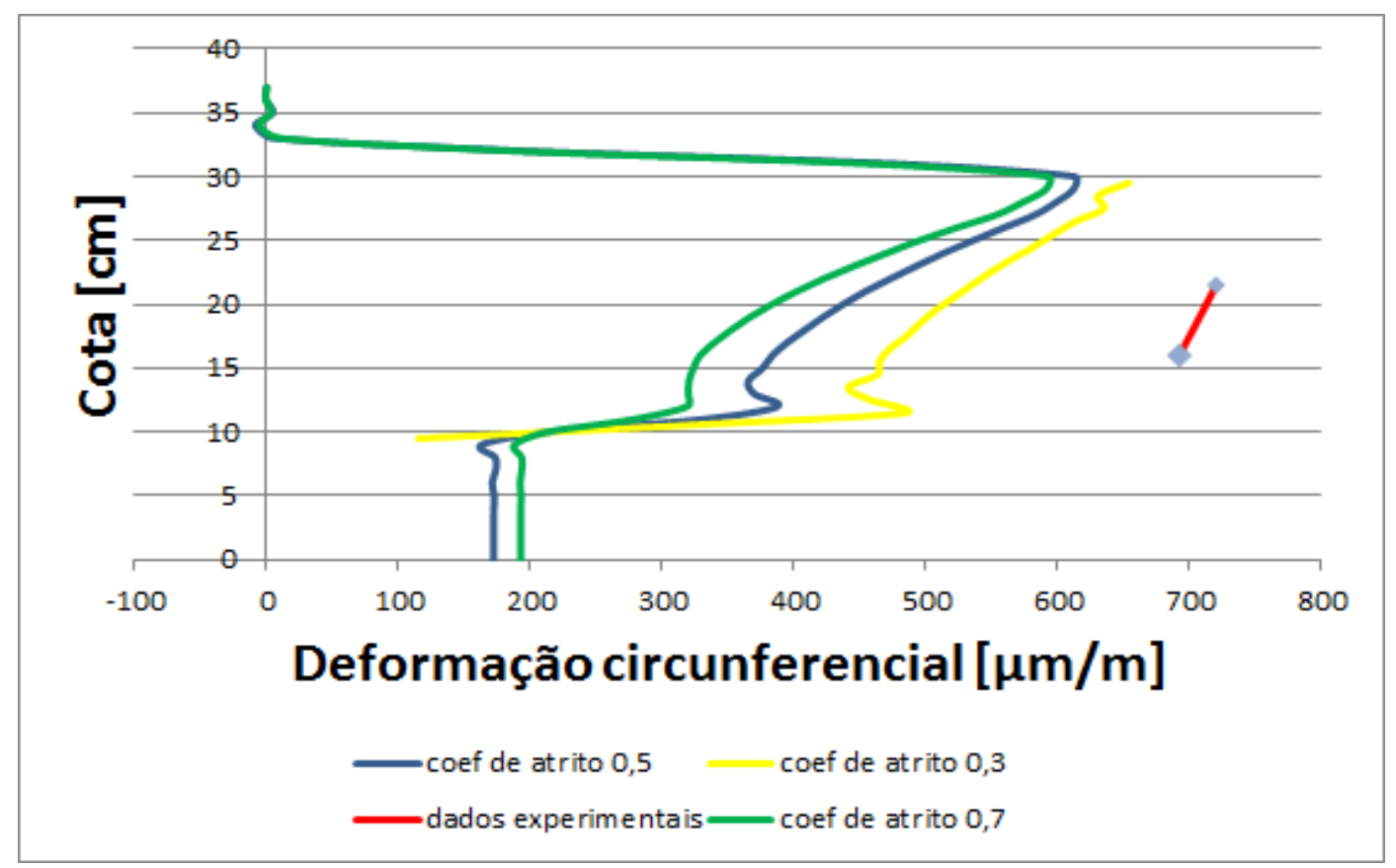

Figura 5.6: Distribuição de deformação circunferencial ao longo da parede do tubo (cm) para diferentes coeficientes de atrito, comparando com os dados obtidos experimentalmente. Modelo elástico equivalente 


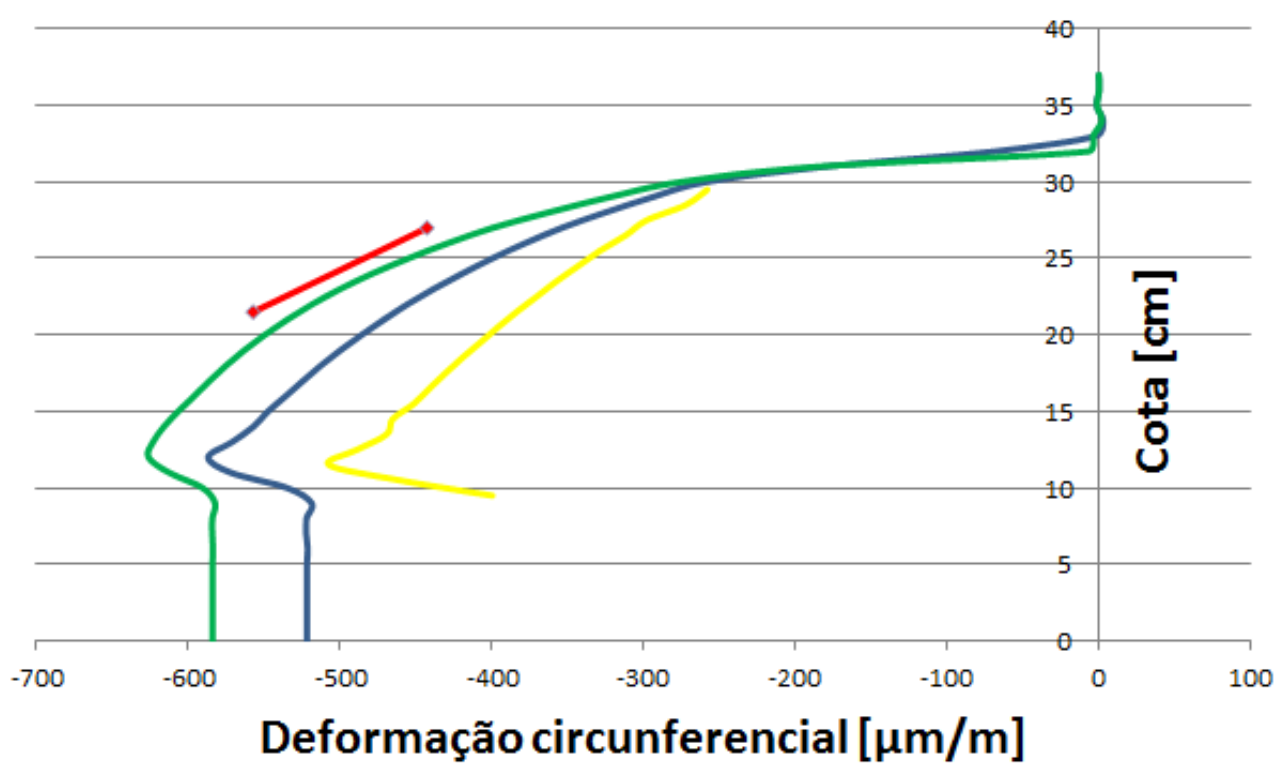

Coef de atrito $0,5 \longrightarrow$ coef de atrito $0,3 \longrightarrow$ dados experimentais $\longrightarrow$ coef de atrito 0,7

Figura 5.7: Distribuição de deformação longitudinal ao longo da parede do tubo (cm) para diferentes coeficientes de atrito, comparando com os dados obtidos experimentalmente. Modelo elástico equivalente.

O que chamava a atenção é que os resultados experimentais, apesar de reproduzirem a mesma tendência das simulações, apresentavam valores numéricos muito diferentes, principalmente para a deformação circunferencial. Inicialmente creditou-se essa discrepância ao modelo simplificado da areia e com isso se investiu em um modelo que incorporasse seu comportamento plástico e o endurecimento.

Após muitas análises optou-se pelo modelo de Drucker Prager modificado com cap, já descrito no sub-capítulo 2.6.2.

Os resultados das simulações com a incorporação da plasticidade são mostrados nas Figuras 5.8 e 5.9. 


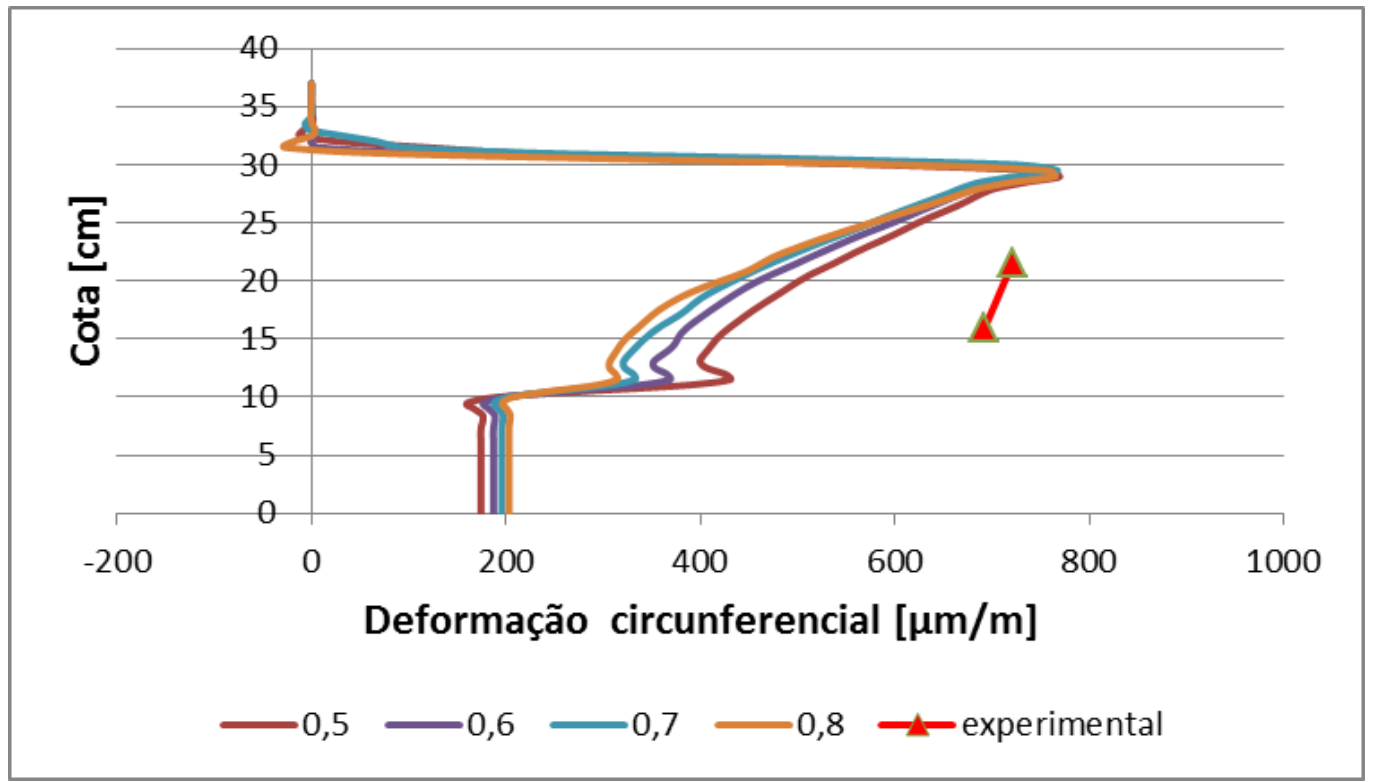

Figura 5.8: Distribuição de deformação circunferencial ao longo da parede do tubo $(\mathrm{cm})$ para diferentes coeficientes de atrito, comparando com os dados obtidos experimentalmente. Modelo elasto-plástico.

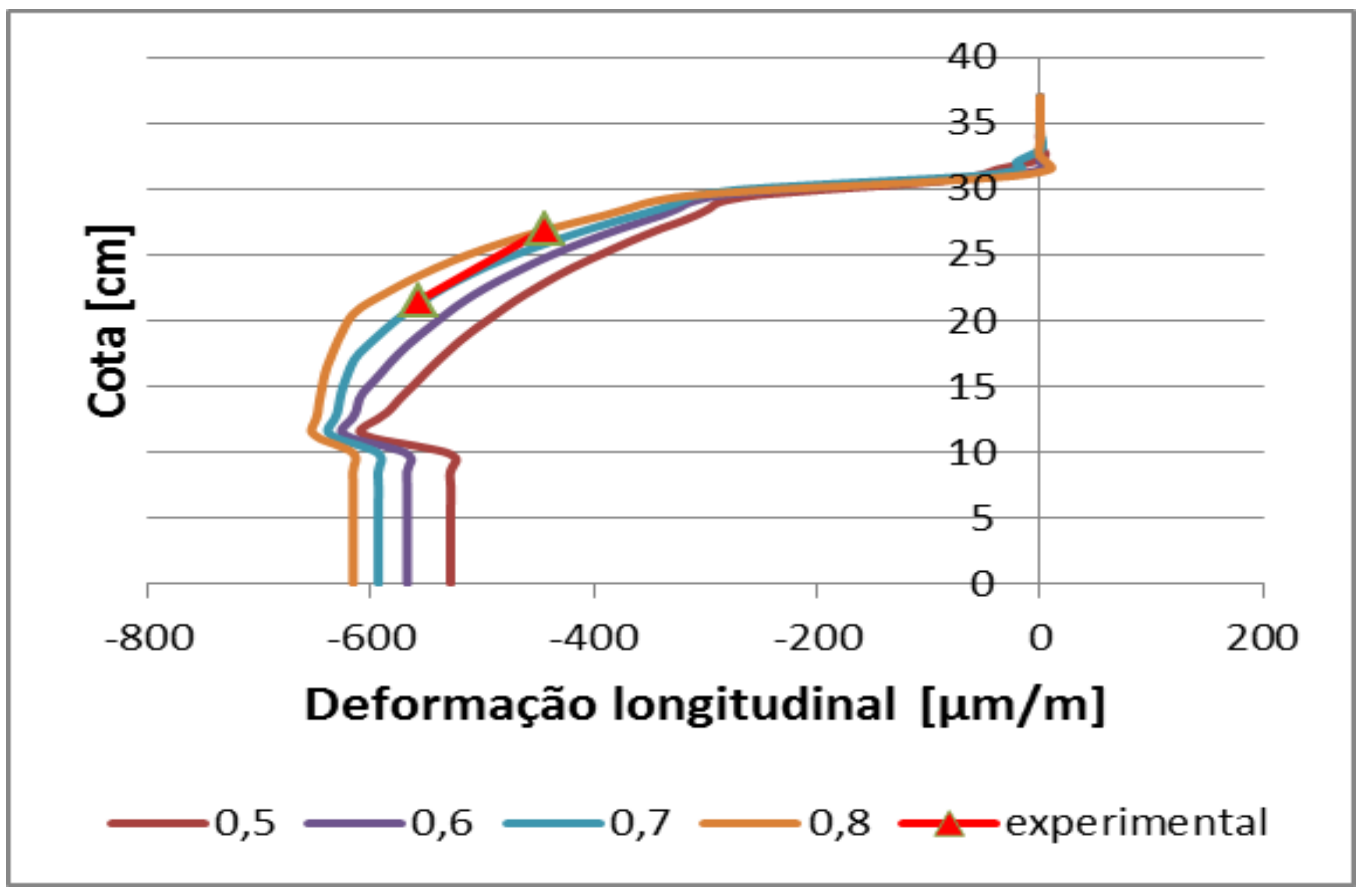

Figura 5.9: Distribuição de deformação longitudinal ao longo da parede do tubo (cm) para diferentes coeficientes de atrito, comparando com os dados obtidos experimentalmente. Modelo elasto-plástico. 
Os resultados mostraram que, a despeito da inclusão da plasticidade no comportamento da areia, ainda persistiam as discrepâncias entre os resultados experimentais e as simulações.

Inicialmente as suspeitas recaíram sobre o valor de espessura de parede do tubo, mas uma nova verificação atestou que o valor médio dos diâmetros interno e externo do tubo estavam corretos, sendo inclusive compatíveis com os valores nominais fornecidos pela companhia de serviço. Entretanto, verificou-se que os diâmetros interno e externo apresentavam ligeira variação dependendo da direção em que eram medidos, embora na média obedecessem ao valor nominal descrito pelo fornecedor. Isso mostrava que o espécime utilizado no ensaio apresentava geometria irregular, possuindo perfil ligeiramente ovalado. Tal deformidade seria uma possível causa do desvio dos resultados, pois sendo a seção do tubo uma elipse, este tenderia a apresentar uma deformação desigual ao longo da seção, à medida em que o interior do tubo é pressurizado. Tal fato é agravado pelos poucos pontos de medição da deformação na parede do tubo. Além disso, o alto limite de escoamento do material em questão (255 MPa) faz acreditar que tal imperfeição é um aspecto da construção do equipamento, e não uma deformação provocada pela utilização desse tubo em campo ou no laboratório. Desta forma, possivelmente todo espécime escolhido apresentaria suas imperfeições.

Outra hipótese para a distorção dos resultados era a de um carregamento assimétrico. No entanto, espera-se que o posicionamento dos strain gauges em pares opostos minimize esse tipo de influência.

De qualquer forma, a própria distorção dos resultados apresentara um aspecto curioso. Tomando como referência o resultado do experimento do plano inclinado para o coeficiente de atrito com a superfície seca $(0,57)$, se observou que o desvio dos resultados experimentais em relação às curvas de simulação para o referido coeficiente era três vezes maior na deformação circunferencial em relação à deformação longitudinal. Levando-se em conta o coeficiente de Poisson da liga de alumínio $(0,33)$ é de se esperar que uma não idealidade que provoque um desvio "d" na medição da deformação circunferencial provoque da mesma forma um desvio de $-0,33 \mathrm{~d}$ na deformação longitudinal, uma vez que as extremidades do tubo não se encontravam engastadas na aplicação do carregamento. 


\section{2. \\ Modelagem do acunhamento}

\subsection{1.}

\section{Conceito e geometria do modelo}

Para tentar estabelecer um modelo de previsão para o acunhamento em função da resistência da rocha, e ainda avaliar a influência de determinados fatores na ocorrência desse fenômeno, novamente foi utilizado o MEF através do Abaqus.

Foi criado um modelo para reproduzir o gradativo aumento no arraste da amostra de testemunho ao adentrar no tubo, até finalmente culminar no acunhamento.

$\mathrm{Na}$ idealização do modelo, o desafio foi o de adequar a dinâmica do caso real a um modelo mais simples, mais fácil de reproduzir no ambiente virtual. Durante a testemunhagem, o cilindro de rocha é usinado no decorrer da operação, e vai sendo encamisado à medida que é usinado. Desta forma, a extremidade do tubo permanece sempre a uma mesma distância da extremidade inferior do cilindro de testemunho. De modo a evitar agregar complexidade ao modelo, incorporando o aspecto da perfuração do anular ao redor do testemunho, optou-se por uma solução alternativa, mas que ainda assim inclui os aspectos relevantes para o problema em questão.

A idéia adotada foi a de transladar um cilindro representando o testemunho de um tubo inferior a outro, superior (ver Figura 5.10). O tubo superior representa o próprio tubo utilizado nos barriletes de testemunhagem, e no contato entre ele e a amostra foi adotado o coeficiente de atrito encontrado para o contato quando utilizado fluido de perfuração de base aquosa. Já o tubo inferior tem a função de representar o fundo do poço e o engaste da amostra do testemunho em sua extremidade inferior. Por isso restringe a deformação circunferencial do cilindro, mas no contato entre o tubo inferior e o testemunho o atrito é nulo.

O resultado da modelagem consistiu em monitorar a progressão dos esforços sobre o trecho não confinado da amostra de testemunho até seu colapso. O trecho não confinado é representado pela separação de $15 \mathrm{~cm}$ entre as extremidades dos tubos inferior e superior. 


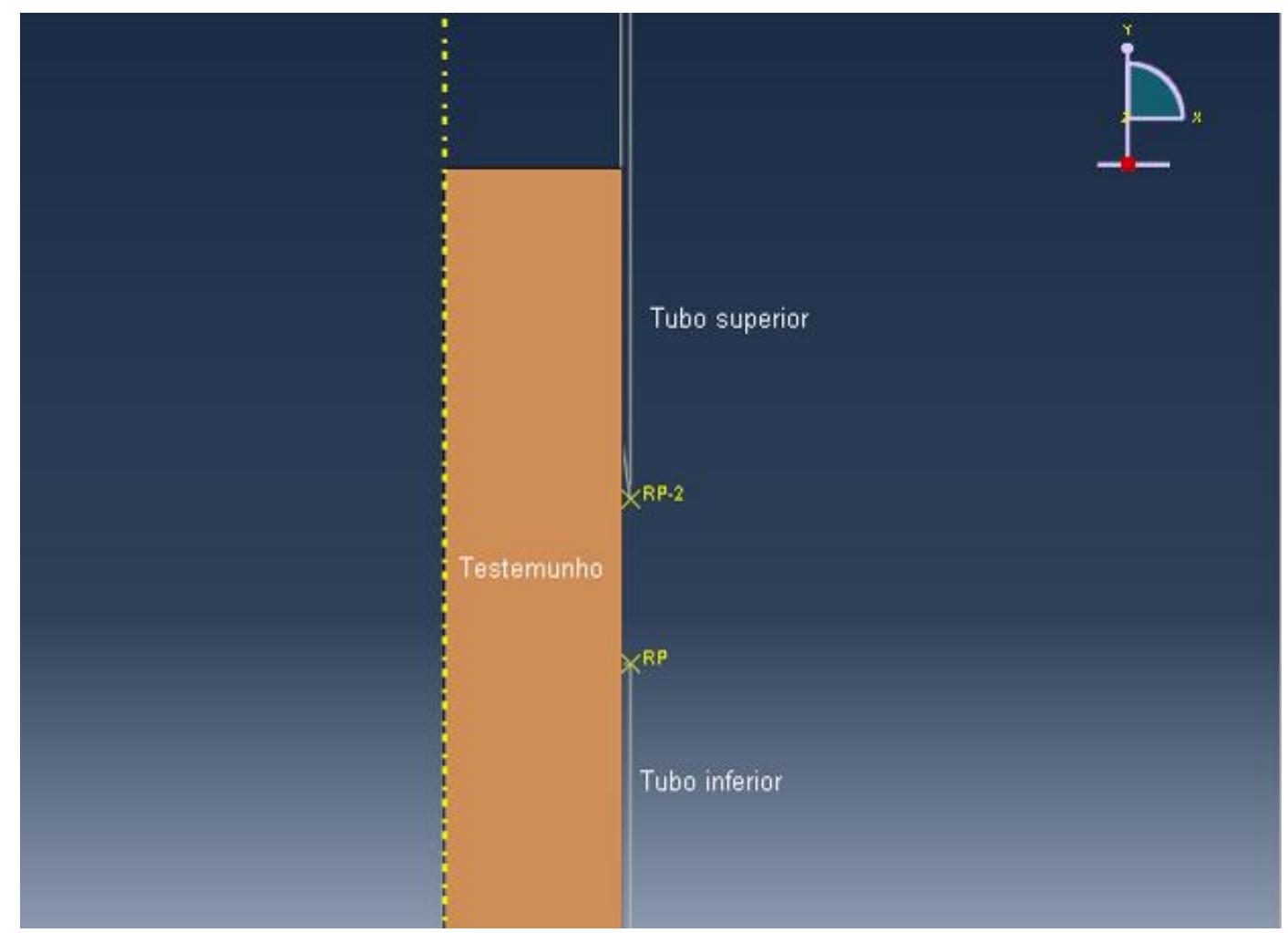

Figura 5.10: Modelo axissimétrico incorporando a amostra de testemunho,o tubo utilizado na testemunhagem e um segundo tubo que têm o papel de simular o engaste da coluna de rocha em sua extremidade inferior

$\mathrm{Na}$ situação real, o testemunho, por possuir diâmetro ligeiramente menor que o diâmetro de passagem do tubo, não estará necessariamente em contato com o tubo em toda sua extensão. Somente após a desagreção parcial da amostra de arenito pela vibração e/ou relaxação a decantação dos detritos inicia esse contato. Entretanto, é inviável prever o momento em que se inicia e o grau em que o contato ocorre. Desta forma, o modelo supõe um contato pleno, levando a resultados mais conservadores do que acontece na prática. Exemplificando, uma rocha frágil pode apresentar uma razoável variação no comprimento que admite ser testemunhada, dependendo do momento em que se inicia o contato entre a amostra e o tubo. O modelo proposto representa o pior caso possível. Inclusive, por esse motivo, foram desenhados o tubo e amostra com um comprimento de apenas $2 \mathrm{~m}$, o que permite uma translação suficiente para um arraste que cause o colapso da amostra.

$\mathrm{Na}$ condição inicial o testemunho já se encontra $10 \mathrm{~cm}$ encamisado pelo tubo superior. A intenção foi evitar eventuais distorções provocadas na simulação no início do contato. Na entrada do tubo foi incluído um bisel (Figura 5.11) de 
modo a minimizar a influência da expansão lateral da amostra não-confinada na entrada do tubo. Como o bisel possui $2 \mathrm{~cm}$ de comprimento, o contato inicial entre o testemunho e o tubo é de $8 \mathrm{~cm}$.

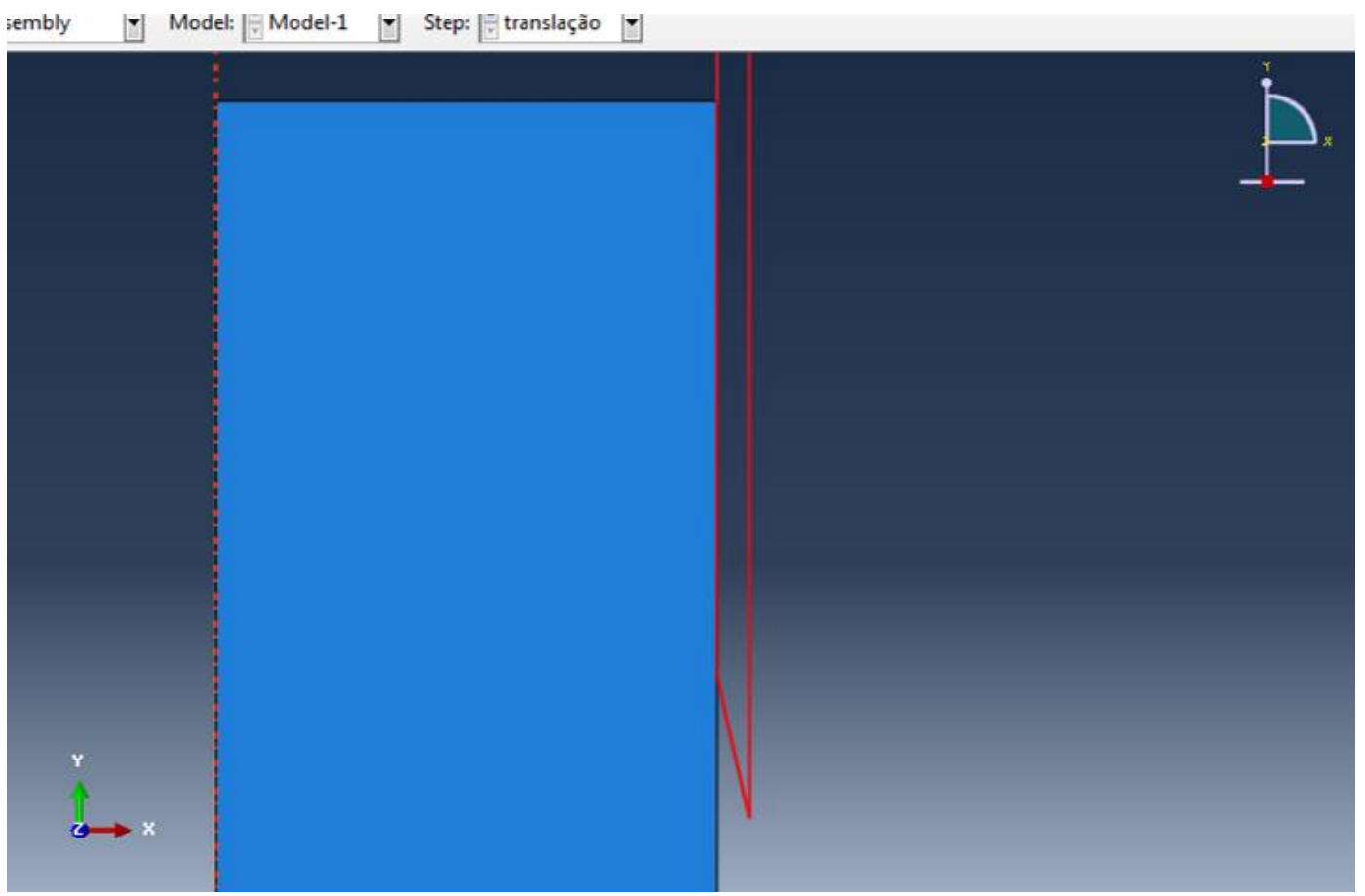

Figura 5.11: Detalhe do bisel na extremidade do tubo minimizando interferência na entrada da amostra no interior do tubo

Foram criados modelos em duas dimensões diferentes comportando os sistemas para amostras de 4 e 5,25 polegadas.

\subsection{2.}

\section{Propriedades dos Materiais}

Optou-se por uma simplificação, modelando os tubos que envolvem o testemunho como analítico rígido. Procurando assim diminuir o volume de dados a serem processados, e consequentemente, o tempo de simulação. Julgou-se que tal simplificação tem pouco efeito no resultado uma vez que o módulo de elasticidade da liga de alumínio e substancialmente maior do que o da própria rocha. Além disso, a maioria das companhias de testemunhagem empregam o uso de tubos de alumínio com espessura de parede ainda maior do que o tubo utilizado no ensaio em laboratório, aumentando ainda mais sua rigidez, e também fazendo 
com que a modelagem não fosse direcionada ao caso particular de determinado equipamento.

Para a amostra de rocha foram adotadas propriedades elásticas típicas do arenito turbidítico que compõe a zona de interesse de vários reservatórios da Bacia de Campos. Estes valores foram obtidos pelo próprio Laboratório de Mecânica das Rochas Petrobras a partir de informações de ensaios geomecânicos em rochas similares:

- Coesão aparente $(\mathrm{C})=2,58 \mathrm{MPa}$;

- Ângulo de atrito interno $(\Phi)=26,8^{\circ}$;

- $\quad$ Módulo de Young (E) = 3,26 GPa;

- Coeficiente de Poisson $(v)=0,347$.

A resistência à compressão simples (UCS) foi inferida indiretamente, a partir dos dados da coesão e ângulo de atrito através da seguinte relação:

$$
U C S=\frac{C \cdot 2 \cdot \cos \emptyset}{(1-\sin \emptyset)}
$$

Assim, o valor de UCS é:

$$
\mathrm{UCS}=8,387 \mathrm{MPa}(1216,5 \mathrm{psi})
$$

As propriedades listadas foram inseridas através de três comportamentos: densidade, deformação elástica e plasticidade através do critério de MohrCoulomb. 


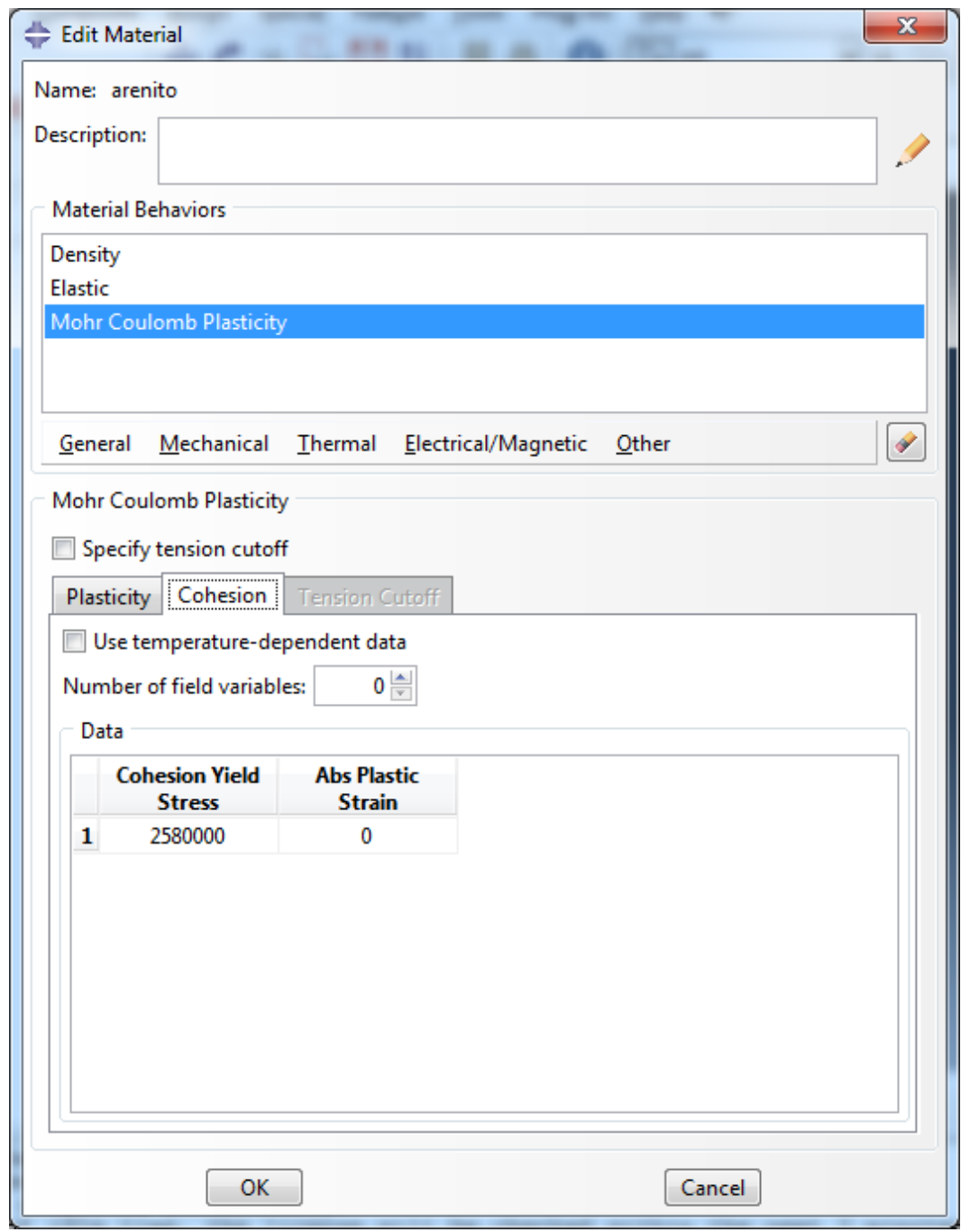

Figura 5.12: Janela de inserção dos parâmetros do arenito

\subsection{3.}

\section{Dinâmica e condições de contorno}

No passo inicial foram aplicadas as condições de contorno, restringindo o deslocamento dos tubos, e provisoriamente restringindo também o deslocamento da base do testemunho.

Foram criados dois passos após o passo inicial. O primeiro deles comporta a aplicação da gravidade na direção do eixo -z e a aplicação opcional de uma pressão sobre o topo do testemunho, simulando a influência do fluido, que oferece resistência à entrada do testemunho. 
Foram realizadas simulações com diferentes valores para o carregamento no topo para observar a sensibilidade à essa variável. De qualquer forma procurou-se estimar qual seria na prática esse valor.

O Simcarr é um software criado para avaliar o escoamento, as pressões e o carreamento de cascalho durante as fases de construção do poço. No entanto, nesse caso foi adaptado para avaliar o escoamento no interior de um barrilete de 9 metros e diâmetro de 6,75 polegadas (barrilete utilizado em testemunhagens em poços de 8,5 polegadas.

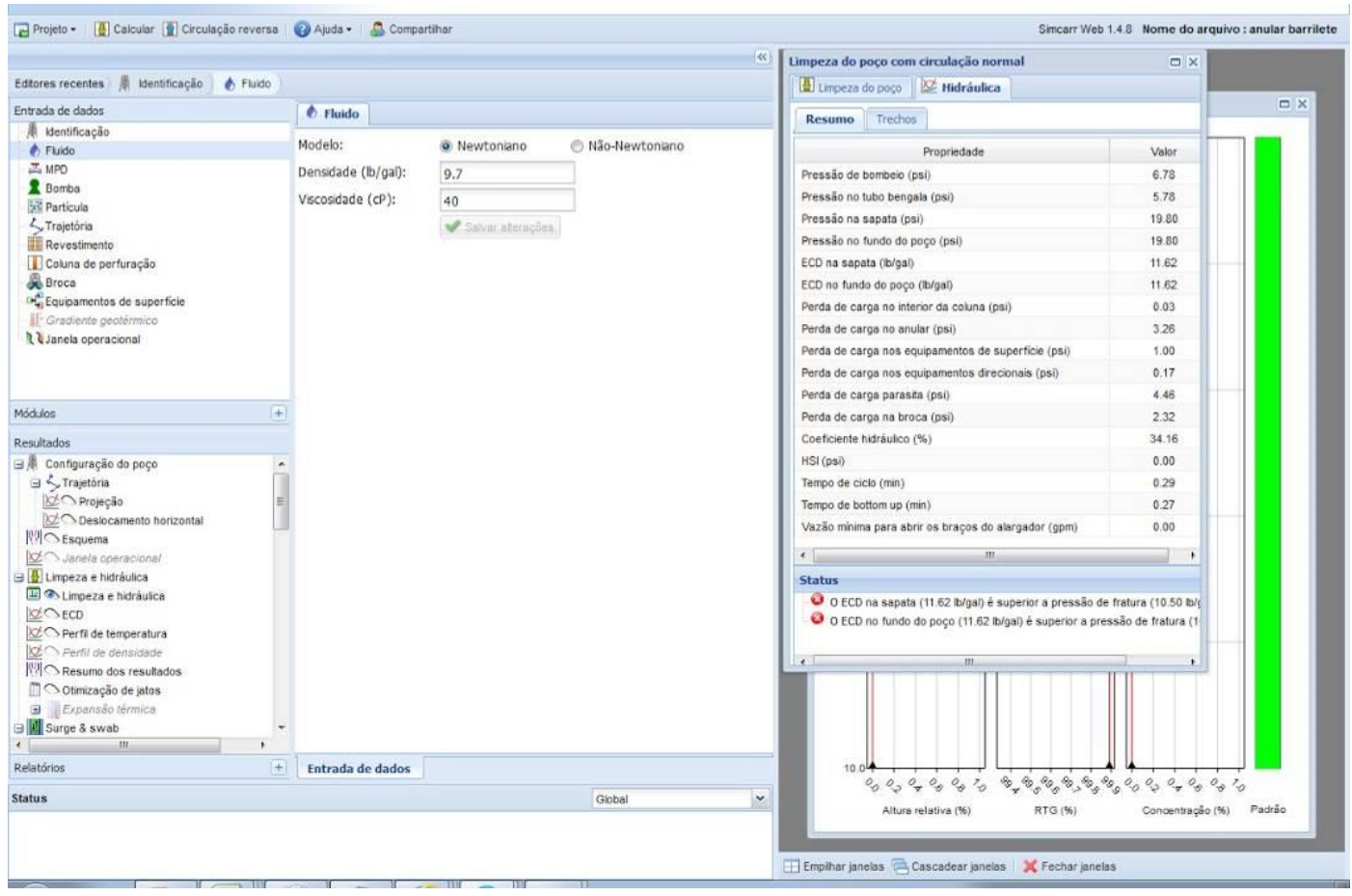

Figura 5.13: Tela do Simcarr, utilizado para a estimativa do diferencial de pressão sobre a esfera desviadora de fluxo

Foram então adotados os parâmetros comumente utilizados nas testemunhagens de referência:

- Vazão de circulação: 80 gpm;

- Densidade do fluido: 9,7 lb/gal;

- Viscosidade do fluido: $40 \mathrm{cP}$;

Encontrou-se uma perda de carga de 3,26 psi no anular e 2,32 psi nos orifícios de desvio do fluxo, totalizando 5,58 psi (38473 Pa). Esse valor foi 
adotado em algumas das simulações como o esforço no topo do testemunho e considerado o valor de referência para o caso real.

O último passo se destina à translação. Nesse caso, a condição de contorno criada no passo inicial que restringia o deslocamento da base é modificada para um movimento ao longo do eixo z. A condição de contorno permite um deslocamento de até 1,8 m embora a simulação seja finalizada no momento em que ocorre a deformação plástica.

A aquisição dos dados foi discretizada em 20 estágios igualmente espaçados ao longo da translação.

\subsection{4. Malha e tipo de elementos utilizados}

Para modelos axissimétricos, o Abaqus não oferece uma vasta seleção de opções de elementos. Mesmo porque a simplicidade geométrica de tal modelo diminui essa exigência. Para o modelo da amostra de testemunho foi adotado o elemento CAX4R.

CAX4R: A 4-node bilinear axisymmetric quadrilateral, reduced integration, hourglass control.

Foi definido um tamanho aproximado de $0,4 \mathrm{~cm}$ para cada elemento quadrilatero na simulação com testemunho de 4 polegadas e $0,5 \mathrm{~cm}$ na simulação com testemunho de 5,25 polegadas resultando em uma malha com 13 e 14 elementos ao longo do raio do testemunho respectivamente. Essa dimensão foi determinada constatando-se a melhor resolução que resultasse em baixa distorção dos elementos e um razoável tempo de simulação. 


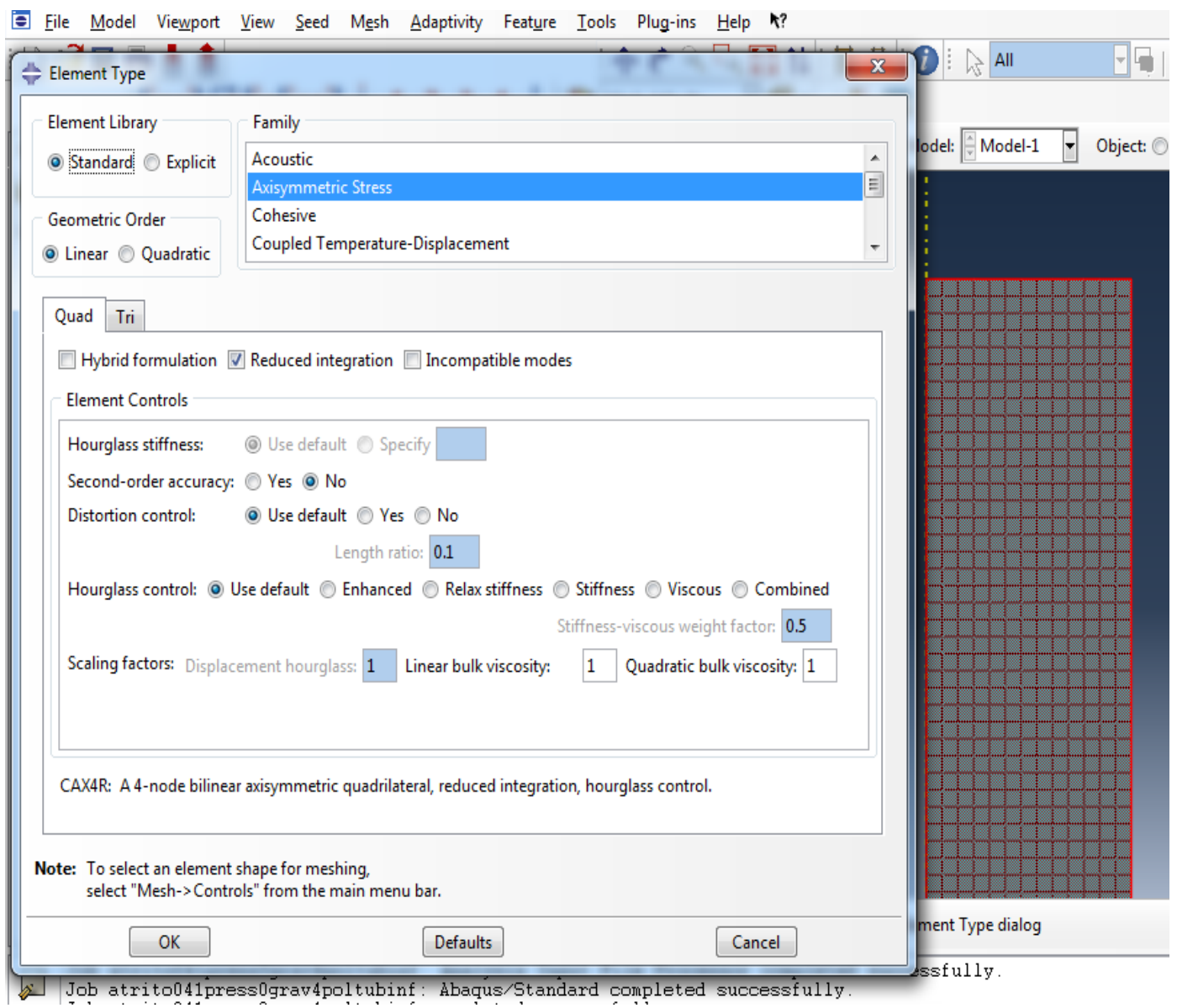

Figura 5.14: Seleção do tipo do elemento que compõe a malha

\subsection{5. \\ Interação entre as superfícies}

$\mathrm{Na}$ interação entre as superfície foi optado o Método Cinemático ao invés do Método de Penalidade, pois este último costuma diminuir o incremento de tempo necessário entre as iterações tornando o tempo da simulação ainda mais longo.

Quanto à formulação do deslizamento, o deslizamento finito era nesse caso a única opção devido à magnitude do deslizamento entre as superfícies.

\subsection{6.}

\section{Resultados dos modelos em EF para o acunhamento}

O modelo determina a compressão axial máxima aplicada sobre o trecho não confinado da amostra de rocha em função da translação da amostra de testemunho tubo adentro. É importante lembrar, mais uma vez, que no caso real 
este contato entre a amostra e o tubo não existe em sua totalidade, ou pelo menos não desde o início da testemunhagem. $\mathrm{Na}$ prática o cilindro da amostra de testemunho possui diâmetro ligeiramente menor do que o diâmetro interno do tubo, diferente da simulação. Somente após uma desagregação parcial da rocha já testemunhada e encamisada pelo cilindro se inicia este contato, desta forma não ocorrendo de forma plena ao longo de toda sua extensão. Sendo assim, o modelo em questão, a priori, não relaciona o esforço sobre a rocha que a levará ao colapso em relação ao comprimento testemunhado, mas simplesmente em relação à extensão em contato.

Ao colher os resultados da tensão no trecho não confinado não se considerou as regiões de concentração de tensão próximos às extremidades dos tubos (ver Figura 5.15) por serem provocadas por simplificações na geometria inexistentes na situação real. Exemplificando, uma vez que a coroa de testemunhagem tem seu perfil radial suave e parabólico, a interface entre a extremidade inferior da coluna de testemunho e o fundo do poço não forma um ângulo reto.

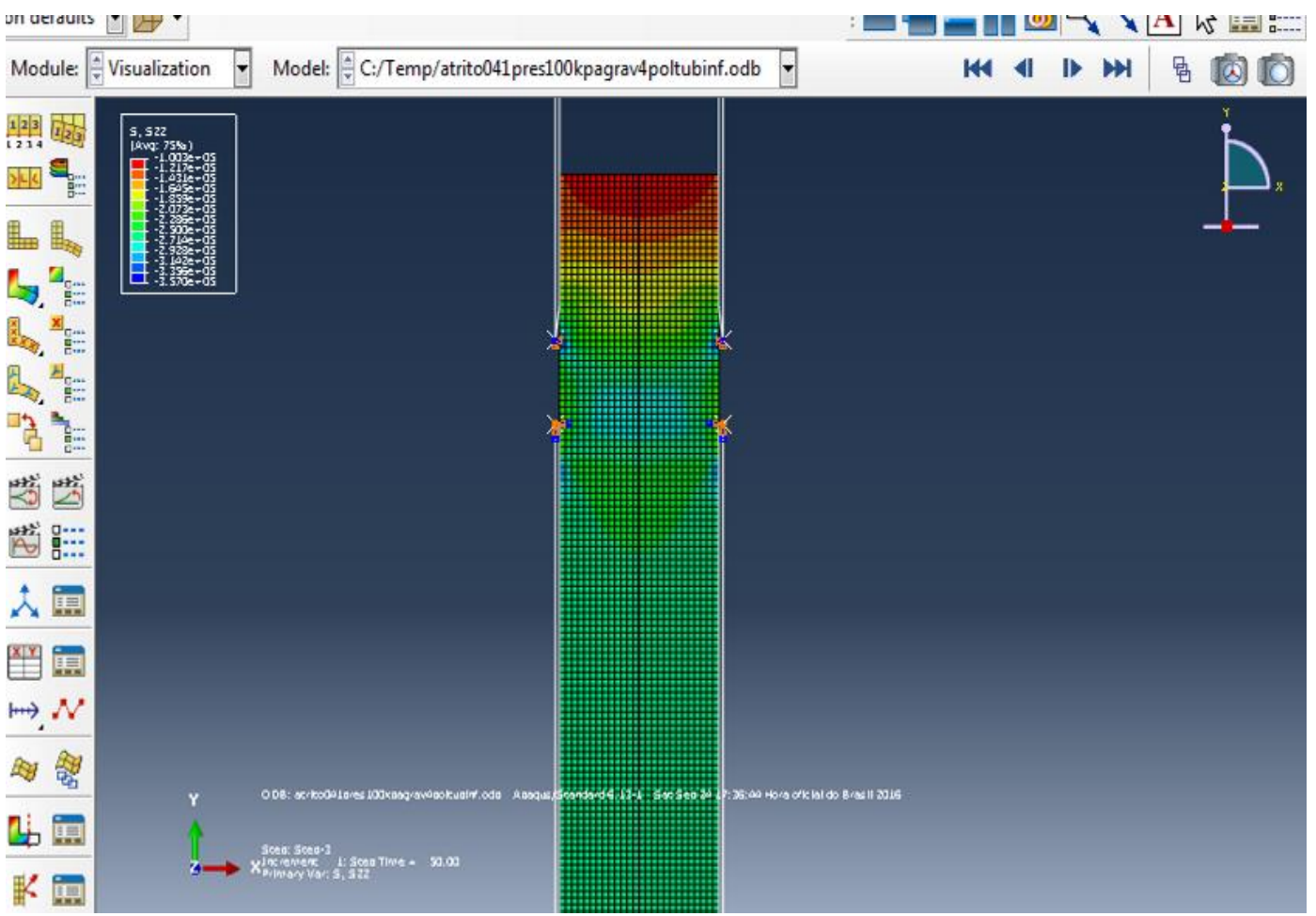

Figura 5.15: Mapa de cores mostra as concentrações de tensão, em vermelho o carregamento no topo exercido pelo fluido; em azul claro a zona de maior tensão axial no trecho não confinado 


\subsubsection{1. Resultados: simulações com diferentes tensões no topo}

A Figura 5.16 mostra a influência da tensão axial inicial no testemunho. Foram plotados o comportamento do arraste em função da translação do testemunho para a condição somente com força da gravidade e com diferentes tensões aplicadas ao topo da amostra. Tal análise ilustra a sensibilidade da tensão de topo na ocorrência do acunhamento. Observa-se, por exemplo, que o projeto de um sistema capaz de reduzir substancialmente a pressão exercida pelo fluido permitiria o dobro de translação em contato, em relação à condição de referência (com $38470 \mathrm{~Pa}$ de tensão no topo). A linha pontilhada delimita a resistência compresiva da rocha, e em todos os ensaios coincidiu com o ponto onde se iniciou a deformação plástica da amostra. 


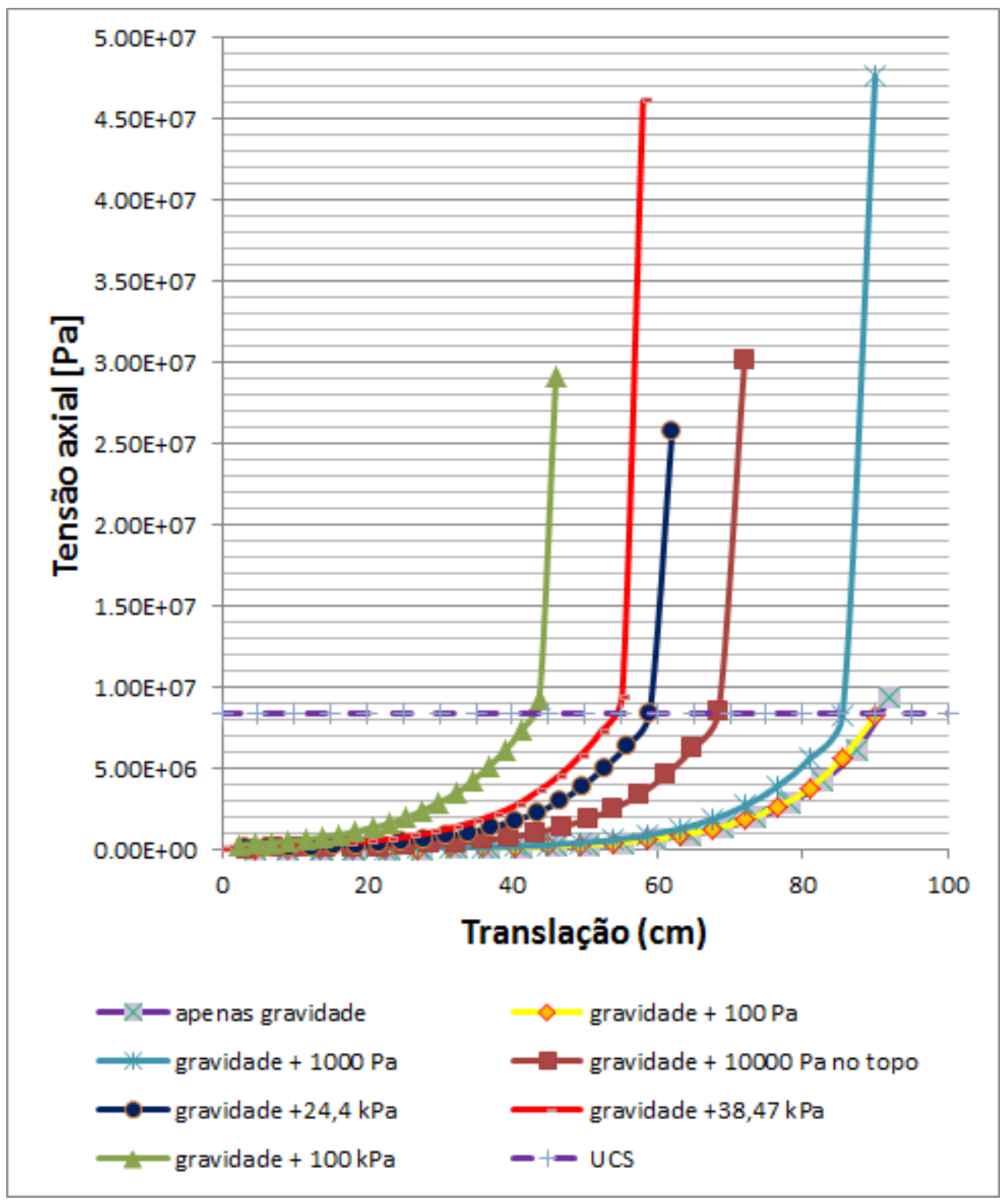

Figura 5.16: Resultados de diversas simulações com diferentes tensões no topo, todas elas para testemunho de 4 polegadas e utilizando o coeficiente de atrito para fluido de base aquosa $(0,41)$ 


\subsubsection{2.}

\section{Resultados: comparação entre os diferentes diâmetros e fluidos de perfuração}

Na Figura 5.17 foram plotados os resultados para os diâmetros de 4 e 5,25 polegadas, e com os coeficientes de atrito estimados para fluidos de perfuração de base aquosa ou sintética, sempre com $38470 \mathrm{~Pa}$ de tensão no topo. A Figura ilustra a influência destes dois parâmetros (diâmetro e coeficiente de atrito) no arraste.

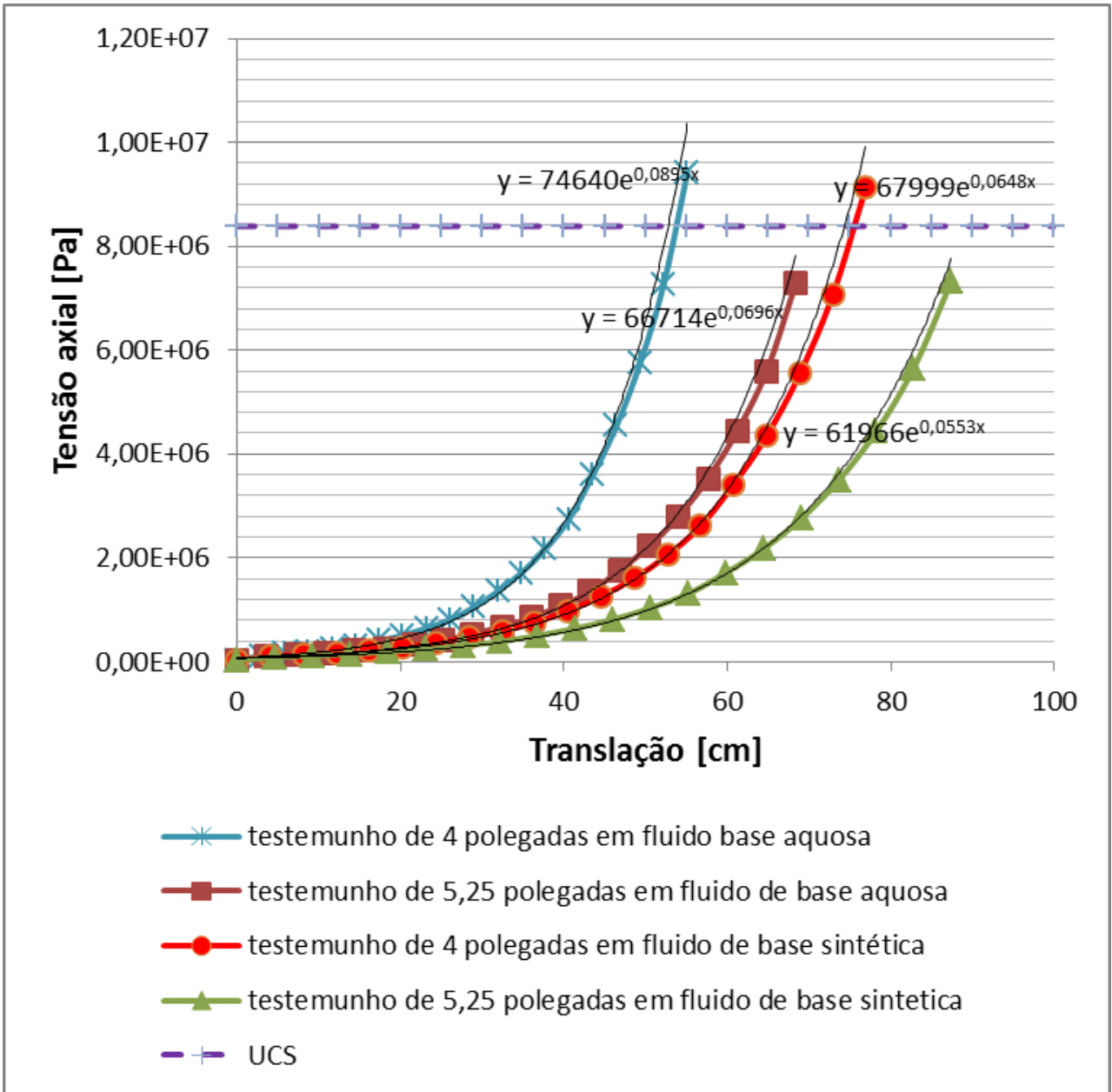

Figura 5.17: Comparação entre os resultados das simulações com diferentes diâmetros e fluidos de perfuração, tensão no topo de $38470 \mathrm{~Pa}$ 


\subsection{7.}

\section{Comparação entre os resultados da simulação e o modelo analítico}

Acompanhando os resultados exibidos na Figura 5.17 encontram-se as funções exponenciais mais adequadas a cada um. Comparou-se então os parâmetros A e B, multiplicador e expoente, obtidos das simulações com os obtidos analiticamente conforme exposto no capítulo 2.3:

$$
\sigma_{y}=\sigma_{y i} . e^{\frac{4 \cdot \mu}{D} \cdot\left(\frac{v}{1-v}\right) \cdot l}=A e^{B . l}
$$

Quanto ao parâmetro A, que corresponde à tensão axial inicial no trecho não confinado, é importante esclarecer que o valor considerado como teórico também foi obtido a partir da simulação, como o ponto de maior tensão axial antes de iniciar a translação. Esclarecendo melhor, a pressão aplicada sobre o topo do cilindro de rocha (38470 $\mathrm{Pa}$ ) chega à base do testemunho já atenuada pelo próprio atrito entre a amostra e o tubo. Desta forma, valeu-se do resultado gerado pela própria simulação de forma a dispor como ponto de partida um valor mais realista em relação à adoção do valor da pressão no topo.

A tabela ilustra a comparação, e o que se vê é um valor do expoente $B$, que reflete o grau da curvatura dos resultados, muito próximo entre o modelo analítico e o simulado.

\begin{tabular}{ccccc}
\hline Tensão axial inicial (Pa) & $\mathbf{2 9 0 0 0}$ & $\mathbf{3 2 0 0 0}$ & $\mathbf{3 1 5 0 0}$ & $\mathbf{3 4 2 0 0}$ \\
\hline $\begin{array}{c}\text { Diâmetro (cm) } \\
\text { coeficiente de atrito }\end{array}$ & $\mathbf{1 0 , 1 6}$ & 13,335 & 10,16 & 13,335 \\
A (modelo) & 74640 & 0,41 & 0,336 & 0,336 \\
A (teórico) & 29000 & 32000 & 31500 & 34200 \\
B (modelo) & 0,0895 & 0,0696 & 0,0648 & 0,0553 \\
B (teórico) & 0,080951 & 0,061677 & 0,06634 & 0,050545 \\
\hline
\end{tabular}

Tabela 5: Comparação entre os resultados da simulação e o modelo analítico 
Para o parâmetro A os valores não estão assim tão próximos, entretanto tal diferença é plenamente justificada. Como se buscava conhecer o limite de translação até o início da ruptura da rocha, as curvas da Figura 5.17 foram traçadas a partir dos valores máximos de tensão axial no trecho não confinado, e não a partir dos valores médios. Isso fez com que a curva exponencial fosse deslocada para cima sendo forçada a interceptar o eixo y mais acima do que deveria.

O aspecto importante a se destacar é que os resultados da simulação corroboram o modelo analítico proposto, encorajando a adoção de tal modelo como o comportamento do aumento do arraste após o início do contato entre a amostra e o tubo. 


\section{6 \\ Conclusões e perspectivas futuras}

6.1. Conclusões

A metodologia aplicada neste trabalho sofreu sucessivas alterações desde o primeiro planejamento. Após deparar com grandes obstáculos, principalmente na realização dos experimentos idealizados, a abordagem adotada necessitou ser alterada inclusive após a apreciação dos resultados.

$\mathrm{Na}$ obtenção do coeficiente de atrito, por exemplo, o experimento projetado não apresentou resultados diretos da maneira que se pretendia. No entanto, uma adaptação no processamento de seus resultados permitiu uma determinação indireta da variável, e o resultado corroborou o valor obtido no experimento do plano inclinado. Esse último sendo um experimento no qual inicialmente não se creditava grande importância, por crer que sua simplicidade implicaria em grandes limitações. Ao invés disso, o plano inclinado foi uma parte importante do trabalho pois inclusive permitiu a avaliação da influência dos diferentes fluidos de perfuração no coeficiente de atrito, algo que se almejava desde o início.

Utilizando o coeficiente de atrito obtido para o fluido de base aquosa (utilizado na maioria das testemunhagens de referência), determinou-se então, através de simulações, a relação entre o esforço de arraste da amostra de testemunho em função de seu comprimento de contato com o interior do tubo utilizado na testemunhagem. As simulações foram, na maioria dos casos, realizadas com a incorporação de um esforço no topo do testemunho, representando a resistência provocada pela presença do fluido de perfuração no interior do tubo. As simulações mostraram que um reduzido nível de pressão (a partir de $1 \mathrm{kPa}$ ) já é suficiente para influenciar os resultados. A determinação desse componente no caso real é dificílima, já que depende de diversas variáveis como: características de cada sistema de testemunhagem, viscosidade do fluido, pressão de circulação, etc.. Ainda assim, se utilizou o software Simcarr, originalmente destinado à simulação do carreamento dos cascalhos durante a perfuração, para mensurar a pressão exercida pelo fluido no topo do testemunho, considerando parâmetros de entrada típicos à maioria das testemunhagens nesse 
tipo de rocha (vazão, densidade do fluido, dimensões do barrilete). Esse valor encontrado foi considerado como o valor de referência para a pressão sobre o topo, embora simulações com diferentes carregamentos tenham sido realizadas.

Exemplificando, os resultados mostraram que, para o testemunho de 4 polegadas, em fluido de base aquosa, pressão de topo $38,47 \mathrm{kPa}$ e o arenito em questão tolera uma translação de cerca de $55 \mathrm{~cm}$ até que ocorra a plastificação no trecho não confinado. Lembrando que a simulação inicia com $8 \mathrm{~cm}$ da amostra já em contato, isso significa cerca de $63 \mathrm{~cm}$ de encamisamento até o colapso. Simulações com fluido de base sintética e/ou com o maior diâmetro da amostra apresentaram valores maiores.

Felizmente os resultados das simulações apresentaram grande proximidade com o modelo analítico proposto, o que corrobora as premissas adotadas e valida sua utilização.

Tanto nas simulações quanto no modelo consideramos o testemunho inteiramente em contato com o tubo, algo que na prática não deve acontecer desde o início da testemunhagem. Sendo assim os resultados das simulações tendem a ser conservadores em relação à média dos casos reais mostrados no Anexo 2. Um acunhamento pode ocorrer de forma tardia em função do momento em que o contato da amostra com o tubo se inicie.

A questão que permanece é exatamente se é possível dispor de uma razoável previsão de que momento o contato se inicia. Sabemos que a vibração durante a operação é um fator determinante na desagregação da rocha, e por ser um processo dependente de tantas variáveis se torna de difícil quantificação. No entanto, um segundo possível fator determinante na desagregação da rocha seria o relaxamento da rocha pelo alívio das tensões. Resta determinar qual o grau de influência da relaxação na desagregação da amostra de arenito inconsolidado.

Um aspecto particularmente interessante deste trabalho foi o de, pela primeira vez, avaliar cientificamente questões que os profissionais que trabalham com testemunhagem julgavam apenas através do empirismo. Um exemplo disso é a questão da relação entre o diâmetro do barrilete e testemunho e a previsão da ocorrência do acunhamento. Essa é uma questão importante pois oferece subsídios para uma avaliação do desempenho da testemunhagem mesmo em outros tipos de rocha, mais resistentes. No carbonato do pré-sal brasileiro, por exemplo, já se testemunhou com sucesso quase $70 \mathrm{~m}$ de um testemunho de 5,25 polegadas, mas 
para um testemunho de apenas 4 polegadas não se conseguiu até hoje ultrapassar a marca dos 36 metros, e nunca se teve a certeza do porquê.

Outra suspeita empírica que foi confirmada neste trabalho é a de que, uma vez estabelecido o contato, o arraste aumenta de forma dramática, rapidamente culminando no acunhamento. E talvez esta seja a principal contribuição qualitativa desse trabalho, fornecer às companhias de testemunhagens a diretriz de que, uma vez iniciado o contato, o acunhamento (com o consequente colapso da amostra) não deve tardar a ocorrer. Como exemplo da importância dessa informação, algumas companhias trabalham procurando reduzir o coeficiente de atrito entre a amostra e o tubo, e o trabalho realmente mostra que isso atua de forma positiva, como era de se esperar. No entanto, mostra também que a vantagem obtida é limitada, e que muito mais frutífera seria buscar uma maneira de retardar o início desse contato.

Não se alcançando sucesso nessa ação que seria o objetivo principal, uma alternativa seria empenhar-se na diminuição do atrito, mas associada à diminuição da pressão exercida pelo fluido sobre o topo do testemunho. Quem sabe desta forma conseguindo maximizar os resultados.

\section{2. \\ Dificuldades enfrentadas}

Durante o experimento de compactação da areia e translação do tubo, a execução dessa segunda fase do ensaio levou a resultados de baixo aproveitamento, pois para os valores de compactação aplicados, a areia, após a remoção do carregamento, não mantinha uma energização suficiente de forma a permitir uma considerável resistência à movimentação do tubo. Desta forma tornava-se difícil determinar o ponto de início da movimentação do tubo, em que se vencia o atrito estático. Além disso, a leitura dos extensômetros permanecia dentro de seus limites de incerteza o que impedia determinar a tensão normal exercida pela areia na parede do tubo, fundamental para a determinação do coeficiente de atrito. Tal insucesso foi naquele momento uma grande decepção, mesmo porque se idealizou um experimento para a medição do atrito no próprio 
tubo para detectar particularidades do comportamento do caso real, algo que no fim acabou não sendo possível.

Algumas das demais dificuldades na interpretação dos resultados do experimento foram provocadas pela limitação do número de pontos de aquisição da deformação na parede do tubo. O hardware permitia a leitura simultânea de apenas oito canais. Desta forma apenas as duas rosetas extensométricas posicionadas na região intermediária do tubo foram instrumentadas em suas duas direções, restando 4 canais que foram utilizados para mais dois pontos de medição da deformação axial na região superior do tubo e dois pontos para a medição da deformação circunferencial na região inferior. O ideal seria uma monitoração completa das duas direções em todas as rosetas extensométricas, permitindo uma maior resolução na distribuição dos esforços ao longo do tubo, e permitindo prever e corrigir de forma mais exata um eventual comportamento não axissimétrico.

Imperfeições na geometria do tubo também consistiram em um relevante prejuízo ao trabalho, pois foram a provável causa de uma distorção nos valores de deformação medidos, exigindo uma correção que certamente incorporou uma razoável incerteza na estimativa do coeficiente de atrito.

Podem se listar ainda como dificuldades no experimento: a necessidade de desmontagem de parte da prensa para a acomodação do espécime e uma oscilação cíclica na leitura dos extensômetros, aumentando consideravelmente a incerteza.

$\mathrm{Na}$ simulação em EF no computador, a raiz da maioria das dificuldades foi relacionada à utilização do Abaqus Explicit e a dificuldade deste (e provavelmente de outras ferramentas quando adotando a formulação explícita) em tratar interações e modelar não-linearidades e grandes deslocamentos entre duas superfícies. Essa foi por muitas vezes a causa de erros e tempos elevados de simulação.

Por fim, uma grande, porém inevitável dificuldade é a grande dispersão dos resultados em campo, que impedem uma referência concreta para a calibração do modelo. Condições da sonda, condições de mar, parâmetros de operação, equipamento utilizado, variabilidade nas características da rocha são apenas algumas das inúmeras variáveis que podem estimular a ocorrência antecipada ou tardia do acunhamento. 


\section{3. Perspectivas Futuras}

A expectativa é que algumas das questões respondidas neste trabalho sirvam como diretrizes para o desenvolvimento de produtos ou técnicas de testemunhagem que permitam uma maximização da recuperação em rochas frágeis. É importante lembrar que, embora o foco aqui sejam os arenitos inconsolidados, o modelo analítico obtido nesse trabalho (e comprovado aravés de simulações) para a progressão do arraste da amostra serve em teoria para qualquer tipo de rocha, e depende apenas de uma de suas propriedades, o coeficiente de Poisson (v). No entanto, cabe ressaltar que o mecanismo de ocorrência do acunhamento em rochas mais resistentes está associado à presença ou propagação de fraturas o que faz da sua ocorrência um fenômeno ainda mais imprevisível. Além disso, para a utilização do modelo do presente trabalho em outras rochas seria recomendável a realização de experimento que atestasse o coeficiente de atrito entre o tubo e a rocha em questão.

Como proposta de um estudo complementar a esse trabalho está o desenvolvimento de uma análise que responda se a relaxação de uma amostra de testemunho pelo alívio das tensões poderiam provocar sua desagregação, iniciando o contato com a parede do tubo. Neste caso se recomenda como apoio bibliográfico a tese de doutorado In-situ Stress Determination in Porous Formation [34], na qual o autor utiliza os dados da relaxação para a determinação das tensões in situ. 


\section{Referências Bibliográficas}

1. AL-SAMMAK, I.; AHMED, K.; AL-BOUS, F. Coring Unconsolidated Formation - Lower Fars: A Case Study, SPE Middle East Oil and Gas Conference, Bahrain, SPE 119918, 2009.

2. GUARISCO, P. et al. Maximizing Core Recovery in Lower Tertiary Through Drilling Optimization Service and Intelligent Core Bit Design, SPE/IADC 140070, SPE/IADC Drilling Conference and Exhibition, Amsterdam, Netherlands, 2011.

3. FERREIRA, F. H.; SOUZA, I. S.; SANTOS, E. S. R. Análise de Acunhamento de Testemunho à Luz da Mecânica das Rochas VII Seminário de Engenharia de Poço, Petrobras, Salvador, Brasil, 2007.

4. SINGH, D. P. Determination of some engineering properties of weak rocks, International Symposium on Weak Rock, Tokyo, Japan, 1981.

5. ZHANG, L.; CURRIE, C.; SCHMITT, D. Drilling Induced Core Fractures and Crustal Stress, AAPG Search and Discovery Article \#90172, CSPG/CSEG/CWLS GeoConvention, Calgary, Alberta, Canada, 2010.

6. LAMBE, T. W; WHITMAN, R. V. Soil Mechanics. Massachussets Institute of Technology, John Wiley \& Sons, 1969.

7. ORTIGÃO, J. A. R. Introdução à Mecânica dos Solos dos Estados Críticos, 3를 Edição, Terratek, 2007.

8. Site: www.wikipedia.org versão em inglês, acesso em julho de 2015.

9. Site://imechanica.org/, acesso em julho de 2015.

10. Simulia, Providence, RI, EUA, Manual de Instruções do software ABAQUS, V.6.11., 2011.

11. QUIGLEY, M. C. Advanced Technology for Laboratory Measurements of Drilling Fluid Friction Coefficient, $64^{\text {th }}$ Annual Technical Conference and Exhibition of the Society of Petroleum Engineers, San Antonio, USA, 1989.

12. BOI, G. M. Effect of Mud Composition on Wear and Friction of Casing and Tool Joints, IADC/SPE Drilling Conference, New Orleans, USA, 1985. 
13. Site: www.engineertoolbox.com acesso em setembro de 2015.

14. FJAER, E.; HOLT, R. M.; HORSRUD, P.; RAAEN A. M.; RISNES, Petroleum Related Rock Mechanics, 2 ed., 2008.

15. CHANG, C.; ZOBACK, M.; KHAKSAR, A. Empirical Relations Between Rock Strenght and Physical Properties in Sedimentary Rocks, Journal of Petroleum Science and Engineering 51, 2006. p. $223-237$.

16. PLUMB, R.A. Influence of composition and texture on the failure properties of clastic rocks, SPE/ISRM 28022, Proc. Eurock '94. Delft, Netherlands, pp. 13-20.

17. MOOS, D.; ZOBACK, M.D.; BAILEY, L. Feasibility Study of the Stability of Openhole Multilaterals, SPE Mid-Continent Operations Symposium held in Oklahoma City, Oklahoma, 28-31 March 1999, SPE 52186

18. KELESSIDIS, V. C. Rock Drillability Prediction From In Situ Determined Unconfined Compressive Strength of Rock, The Journal of The Southern African Institute of Mining and Metallurgy, junho de 2011; Vol. 111 pag 429

19. LIMA, B. B. de; VIANA, R. Application of Multiple Techniques to Determine In-situ Directions in Marlin and Albacora Fields, SPE 28711, SPE Petroleum Conference and Exhibition of Mexico, Veracruz, 1994.

20. HOLT, R. Effects of Coring on Petrophysical Measurements; SCA9407.

21. GOODMAN, Richard E. Introduction to Rock Mechanics, John Wiley \& Sons, 1989.

22. BELL, F. G. Engineering Geology, 2 ed., Elsevier, 2007

23. WENG, M.C.; TSAI, L.S.; JENG, F.S.; LIN, M.L. A Constitutive Model for Elastic Visco-plastic Behavior of Weak Sandstones, 11th Congress of the International Society for Rock Mechanics, 2007, Taylor \& Francis Group, London, ISBN 978-0-415-45084-3.

24. VARDOULAKIS, I.; SULEM, J.; OULAHNA, A.; PAPAMICHOS, E. Elasto-plastic behaviour of a weak sandstone, Eurock '96, Barla (ed.)( 1996 Balkema, Rotterdam. ISBN 9054108436 
25. HETTEMMA, M. H. H.; JONES, B. L. Minimizing Coring-Induced Damage in Consolidated Rock, SPE/ISRM 78156, SPE/ISRM Rock Mechanics Conference, Irving, EUA, 2002.

26. BAHRANI, N.; VALLEY, B.; MALONEY, S.; KAISER, P. K. Numerical Investigation of the Influence of Borehole Orientation on DrillingInduced Core Damage, ISRM International Symposium, Estocolmo, Suécia, 2012.

27. RUINA, A.; PRATAP, R. - Introduction to Statics and Dynamics, 2002.

28. Simulia, Providence, RI, EUA, Manual de Instruções do software ABAQUS, V.6.12., 2012.

29. Instituto Francês do Petróleo, Drilling Data Handbook, 1978.

30. American Petroleum Institute, Recomended Practices for Core Analysis, $2^{\mathrm{a}}$ edição, 1998.

31. ALVARADO, G.; COOP, M. R.; WILLSON, S. On the role of bond breakage due to unloading in the behaviour of weak sandstones, Geotechnique 62, nº 4, p. $303-316,2012$.

32. Robinson, L., Drill Bit Nozzle Pressure Loss, AADE Fluids Conference and Exhibition, Houston, EUA, 2010.

33. HOLT, R. M.; BRANDSHAUG, T.; CUNDAL, E.A. Discrete particle and laboratory modelling of core mechanics, ARMA Conference Paper, 2000.

34. DYKE, C.G. Core discing; its potential as an indicator of principal in situ stress directions, Rock at Great Depth, Maury \& Fourmaintraux (eds), Balkema, Rotterdam. ISBN 90 61919754, 1989.

35. MEDEIROS, J. B. Redação Científica: A Prática de Fichamentos, Resumos, Resenhas, 4⿳亠丷a Edição, Editora Atlas, 1999.

36. BLOCH, M., In-situ Stress Determination in Porous Formation, Tese de doutorado, Universidade de Oklahoma, 1999.

37. CHANG, C.; ZOBACK, M.; KHAKSAR, A. Empirical relations between rock strength and physical properties in sedimentary rocks, Jornal of Petroleum Science and Engineering Volume: 51, Issue: 3-4, Pages: 223-237, 2006. 
38. BRANDAS, L. T.; FJAER, E.; TOKLE, K.; TRONWOLL, J. Relating acoustic wave velocities to formation mechanical properties, 46th US Rock Mechanics / Geomechanics Symposium, Chicago, EUA, 2012.

39. ZAHID, S.; KHAN, A.; KHALIL, A. Applications of State of the Art Anti-Jam Coring System - A Case Study, SPE 156208, SPE/PAPG Annual Technical Conference, Islamabad, Pakistan, 2011.

40. SKOPEC, R.; Collee, P.; Tyler, P. Recent Advances in Coring Technology: New Techniques to Enhance Reservoir Evaluation and Improve Coring Economics, Society of Core Analysts Annual Meeting, held in Montpellier,France, September 8-10,1996.

41. Baker Hughes/INTEQ, Coring Handbook, 503-001 Rev. C, 1999.

42. LIMA, B.; VIANA, R. Application of Multiple Techniques to Determine In-situ Directions in Marlin and Albacora Fields, SPE 28711, SPE Petroleum Conference and Exhibition, Veracruz, Mexico, 1994.

43. NEUMANN et al Lessons Learned From a Hundred Frac Packs in the Campos Basin, SPE International Symposium and Exhibition on Formation Damage Control, Lafayette, EUA, 2002.

44. SINOR, L.et al. Development of an Antiwhirl Core Bit, SPE Journal Paper, 1995.

45. American Petroleum Institute, Recommended Practices for Core Analysis, 2 ed., 1998.

46. BLANTON, T. The Relation Between Recovery Deformation and In-Siti Stress Magnitudes, SPE/DOE Symposium on low Permeability, Denver, 1983.

47. HOLT, R., Anisotropic mechanical properties of weakly consolidated sandstone, 6th ISRM Congress, 30 August-3 September, Montreal, Canada, 1987.

48. ALMISNED, O.; SOMERVILLE, J.; SMART, B. Difficulties in Laboratory Characterization of Weak Sandstone, 45th US Rock Mechanics / Geomechanics Symposium, San Francisco, 2011.

49. Site: $\underline{w w w . e s s s . c o m . b r}$ acessado em novembro de 2016 


\section{8 \\ Anexos}

8.1.

Anexo 1 - Dados obtidos a partir da compactação da areia

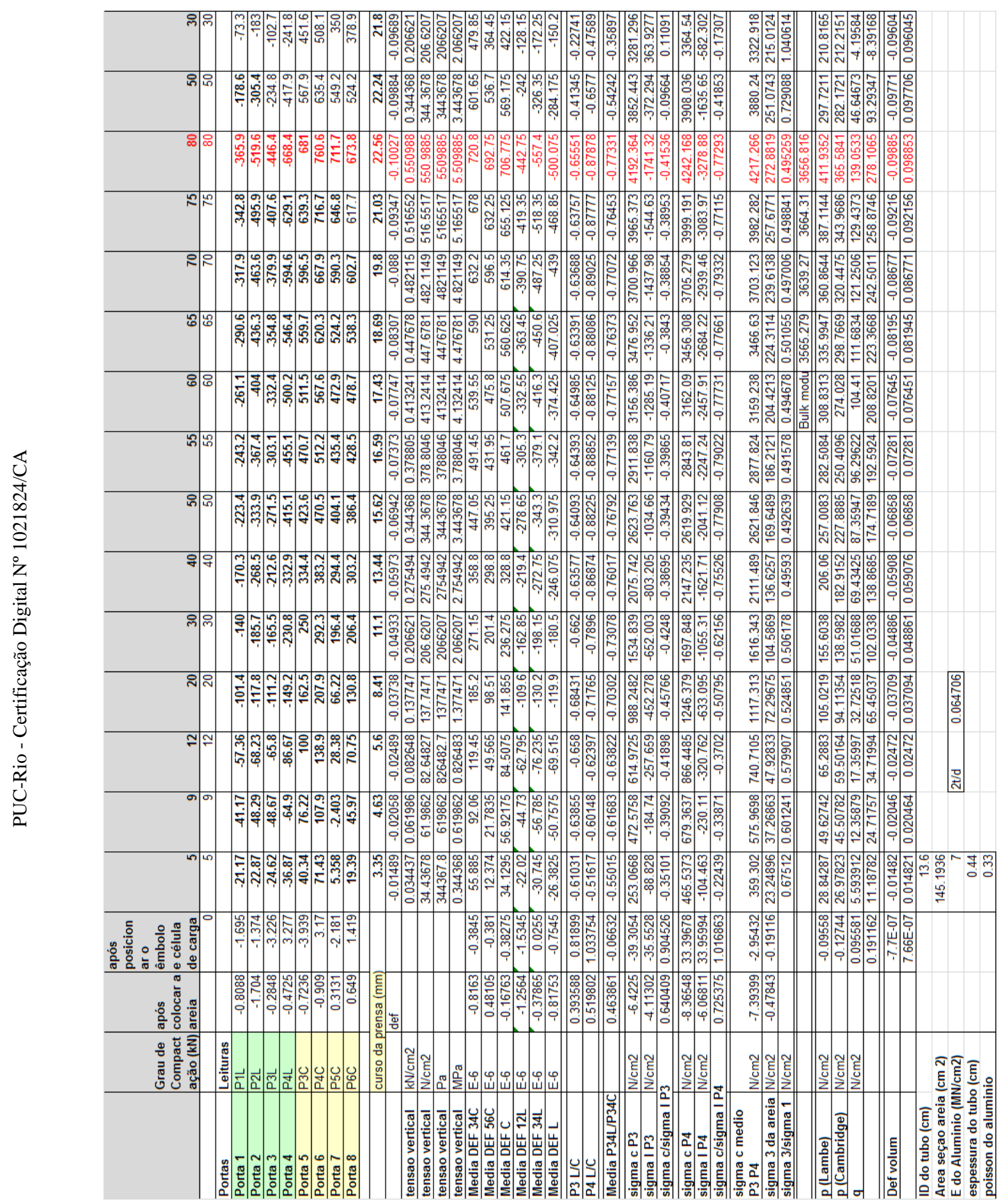


8.2.

Anexo 2 - Recuperação nas testemunhagens no arenito turbidítico de referência

\begin{tabular}{|c|c|c|c|c|}
\hline Campo 1 & Poço 5 & Fluido água & $\begin{array}{l}\text { Amostra } \\
4 \text { pol }\end{array}$ & \\
\hline \# Core & Top (m) & Bottom (m) & $\operatorname{Rec}(\mathrm{m})$ & $\operatorname{Rec}(\%)$ \\
\hline 1 & 2468 & 2477 & 8,18 & 91 \\
\hline 2 & 2477 & 2486 & 6,85 & 76 \\
\hline 3 & 2486 & 2495 & 1,73 & 19 \\
\hline 4 & 2495 & 2504 & 1,51 & 17 \\
\hline 5 & 2504 & 2513 & 0,53 & 6 \\
\hline 6 & 2513 & 2516 & 1,33 & 44 \\
\hline 7 & 2516 & 2519 & 2,6 & 87 \\
\hline 8 & 2575 & 2578 & 2,8 & 93 \\
\hline Campo 1 & Poço 6 & Fluido água & $\begin{array}{l}\text { Amostra } \\
4 \mathrm{pol}\end{array}$ & \\
\hline \# Core & Top (m) & Bottom (m) & Rec.(m) & Rec. (\%) \\
\hline 1 & 2493 & 2495,8 & 2,8 & 100 \\
\hline 2 & 2495,8 & 2499,8 & 2,55 & 64 \\
\hline 3 & 2499,8 & 2502,8 & 2,15 & 72 \\
\hline 4 & 2502,8 & 2507,5 & 4,6 & 98 \\
\hline 5 & 2507,5 & 2514,4 & 6,85 & 99 \\
\hline Campo 1 & Poço 7 & Fluido água & $\begin{array}{l}\text { Amostra } \\
4 \mathrm{pol}\end{array}$ & \\
\hline \# Core & Top (m) & Bottom (m) & Rec. (m) & Rec. (\%) \\
\hline 1 & 2506 & 2509 & 1,55 & 52 \\
\hline 2 & 2509 & 2511,5 & 1 & 40 \\
\hline 3 & 2511,5 & 2514 & 0,9 & 36 \\
\hline 4 & 2514 & 2515,5 & 0,47 & 31 \\
\hline 5 & 2515,5 & 2517 & 0,8 & 53 \\
\hline 6 & 2517 & 2518 & 0,25 & 25 \\
\hline 7 & 2518 & 2521 & 2,15 & 72 \\
\hline 8 & 2521 & 2523,5 & 1,3 & 52 \\
\hline 9 & 2562 & 2565 & 2,76 & 92 \\
\hline 10 & 2565 & 2569 & 3,76 & 94 \\
\hline 11 & 2569 & 2575 & 6 & 100 \\
\hline 12 & 2575 & 2581 & 6 & 100 \\
\hline
\end{tabular}




\begin{tabular}{|c|c|c|c|c|}
\hline Campo 1 & Poço 9 & $\begin{array}{l}\text { Fluido } \\
\text { desconhecido }\end{array}$ & $\begin{array}{l}\text { Amostra } \\
4 \mathrm{pol}\end{array}$ & \\
\hline \# Core & Top (m) & Bottom (m) & Rec. (m) & Rec. (\%) \\
\hline 1 & 2528 & 2531 & 1,45 & 48 \\
\hline 2 & 2531 & 2534 & 0,65 & 22 \\
\hline 3 & 2534 & 2537 & 2,05 & 68 \\
\hline 4 & 2537 & 2540,7 & 3,7 & 100 \\
\hline 5 & 2569 & 2572,45 & 3,45 & 100 \\
\hline 6 & 2589 & 2592 & 2,45 & 82 \\
\hline 7 & 2592 & 2597,5 & 0,3 & 5 \\
\hline 8 & 2597,5 & 2600,5 & 2,2 & 73 \\
\hline 9 & 2600,5 & 2603,8 & 3,3 & 100 \\
\hline 10 & 2603,8 & 2609,8 & 5,55 & 93 \\
\hline
\end{tabular}

